\title{
Exotic Horticultural Plants with Commercial Potential in the United States Market
}

\author{
held at the \\ 91st ASHS Annual Meeting \\ Corvallis, Ore. \\ 9 Aug. 1994
}

\begin{abstract}
sponsored by the
Horticultural Strategies in Developing Countries Working Group Tropical Horticultural Products Research and Development Opportunities Working Group
\end{abstract}

published by the American Society for Horticultural Science

Alexandria, VA 22314-2562

as a special insert in

HortScience 31(5), September 1996 


\title{
Workshop Papers and Authors
}

Presiding: Umedi L. Yadava

Exotic Horticultural Plants With Commercial Potential in the United States Market: Introduction to the Workshop

Umedi L. Yadava

Introduction of Pejibaye for Heart-of-Palm in Hawaii

Charles R. Clement, Richard M. Manshardt, Joseph DeFrank, Catherine G. Cavaletto, and

Natalie Y. Nagai

Ebenus cretica L., An Attractive Endemic Plant of Crete with Potential for Floricultural Use

J.C. Vlahos

Ribes Production in North America: Past, Present, and Future

Danny L. Barney

The Pawpaw [Asimina triloba (L.) Dunal.]: A New Fruit Crop for Kentucky and the United States

Desmond R. Layne

Babaco (Carica pentagona Heilb.): A Possible Crop for the Greenhouse

Chaim Kempler and Todd Kabaluk

Guava (Psidium guajava L.): An Exotic Tree Fruit with Potential in the Southeastern United States

Umedi L. Yadava

Moringa (Moringa oleifera Lam.): A Versatile Tree Crop with Horticultural Potential in the

Subtropical United States

Manuel C. Palada

\section{Exotic Horticultural Plants with Commercial Potential in the United States Market: Introduction to the Workshop}

\author{
Umedi L. Yadava \\ Agricultural Research Station, Fort Valley State College, Fort Valley, GA 31030
}

\begin{abstract}
The 1990 census of the United States revealed a substantial increase in the ethnic diversity of the American population. Federal dietary guidelines recommend that American consumers double their intake of fresh fruits and vegetables. For quite some time, the ethnic diversity of the population and the associated food patterns have been exposing Americans to a panorama of exotic produce from overseas as well as from selected domestic sources (Greene, 1992). The specialty produce industry in the United States is hardly more than 30 years old, but the niche market for these fresh food items is the fastest growing segment of the produce industry (Vietmyer, 1984). Over the last decade, the consumption of produce has increased steadily, whereas the demand for exotic specialties grew exponentially. Consumer awareness of the nutritional value and health benefits of exotics and adventurism to try fascinating and unusual produce and other edibles raise the demand for exotic fruits, vegetables, and other horticultural commodities (Ritchy, 1978). Displays of exotic horticultural special-
\end{abstract}

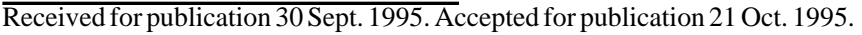
The cost of publishing this paper was defrayed in part by the payment of page charges. Under postal regulations, this paper therefore must be hereby marked advertisement solely to indicate this fact. ties are now becoming a mainstay in supermarkets, with specialty themes ranging from the islands of Asia, Latin America, and the tropics, among others. Shipments of tropical produce and goods rose from $2000 \mathrm{t}$ in 1980 to $70,000 \mathrm{t}$ in 1990 , and to $680,000 \mathrm{t}$ in 1991 , while more than 1,000,000 t of specialty crops were shipped during 1992 and after (Greene, 1992).

Americans not only are more health-conscious but also demand more diverse and ethnically flavored foods. With population shifts, changes in diet, and the persistent fascination of Americans with novelty items, the demand for specialty fruits and vegetables likely will continue to rise through the 1990s and beyond. Domestic production to satisfy ethnic demands for exotic or nontraditional horticultural commodities necessitates developing the technologies to grow these crops locally. To accomplish this objective, there is a definite need for systematic horticultural research to generate the required information for cultivation and management of these crops. Ongoing small- or large-scale research projects at several institutions indicate ample enthusiasm among the horticultural community. These trends demonstrate that an overview of current research efforts on these commodities is appropriate at this time. This workshop precisely served that purpose through a structured open forum for researchers in various 
fields of horticulture. They described their crop and their investigations in this specialty area, i.e., exotic horticultural crops with commercial potential in the U.S. marketplace.

Exotic and nontraditional horticultural crops are presented here in the following order: vegetables, ornamentals, fruits, and miscellaneous crops. In the vegetable crops section, Charles Clement and his coworkers provided a comprehensive discussion on pejibaye or peach palm (Bactris gasipaes Kunth), including planting density trials, germplasm variability, herbicides and artificial mulches, ground covers, and quality evaluation of pejibaye for use as a vegetable. John Vlahos presented the only discussion on an exotic ornamental plant, Cretan silver bush (Ebenus cretica L.), which is an endemic species from Crete. In the fruit crops section, Danny Barney deals with the past, present, and future of Ribes production. Desmond Layne ad- dressed the development of pawpaw [Asimina triloba (L.) Dun.] as a new fruit crop for Kentucky, while Chaim Kempler and Todd Kabaluk explore babaco (Carica pentagonia Heilborn) as a possible new fruit crop for the greenhouse. I report on guava (Psidium guajava L.), an exotic tree fruit with potential for cultivation in the southeastern United States under a fieldhouse for winter protection. In the miscellaneous crops, an article by Manuel Palada describes Moringa oleifera Lamk as a versatile tree crop.

\section{Literature Cited}

Greene, C. 1992. Fruits and vegetables go exotic. Agr. Outlook 189:16-21. Ritchy, S.J. 1978. Nutrition, food habits, and composition of foods of the future. Proc. 27th Annu. Mtg. Agr. Res. Inst., Washington, D.C. Vietmeyer, N.D. 1984. Exotic crops. Reader's Digest 125(748):12-16.

\title{
Introduction of Pejibaye for Heart-of-Palm in Hawaii
}

\author{
Charles R. Clement ${ }^{1}$, Richard M. Manshardt, Joseph DeFrank, Catherine G. Cavaletto, and \\ Natalie Y. Nagai \\ Department of Horticulture, University of Hawaii at Manoa, 3190 Maile Way, Honolulu, HI 96822-2279
}

\begin{abstract}
The pejibaye or peach palm (Bactris gasipaes Kunth, Palmae) is being evaluated in Hawaii as a source of fresh heart-of-palm (Clement et al., 1993). This gourmet vegetable is composed of the tender immature leaves just above the apical meristem wrapped within the petiole sheath of the spear leaf. Mora Urpi et al. (1991) reported that the 2000 t of canned heart-of-palm (valued at $\$ 5$ million) consumed in the United States during 1990 was Euterpe oleracea Mart. and came mostly from Brazil and Costa Rica. During the 1980s, the U.S. market expanded by about $10 \%$ per year (Torres, 1992). Nonetheless, the per capita consumption of $8 \mathrm{~g} \cdot \mathrm{year}^{-1}$ for the United States is much lower than $100 \mathrm{~g} \cdot \mathrm{year}^{-1}$ in France, suggesting that there may be considerable unrealized demand for heart-of-palm.
\end{abstract}

One way to expand this market for peach palm is to shift from a canned to a fresh product. In the gourmet vegetable market, a fresh product commands a premium price over the canned product. The fresh pejibaye heart-of-palm is much superior to the canned product with respect to culinary quality and versatility. When fresh, the heart has a crisp texture; a mild, slightly sweet flavor; a creamy-white color; and an attractive appearance, especially when cut across the axis. When canned, the heart is often mushy (from overcooking), with a metallic, briny, acidic flavor (from the mixture of acetic and citric acids and salt used to preserve it) and a translucent off-white color.

Chefs at gourmet restaurants in Hawaii are enthusiastic about two additional edible products available from the same palm stem (Fig. 1). The edible stem extends 10 to $20 \mathrm{~cm}$ below the apical meristem. It has a crunchier texture, the same flavor, a slightly yellower creamy color, and a uniform appearance when crosscut. The stem is similar to a highquality bamboo shoot, and some chefs prefer it to bamboo shoot or to the heart. The other component, the edible leaf, extends above the heart to the point at which the rachis and leaflets become fibrous. The leaf has two parts: the rachis has a crisp texture, similar to the heart; the leaflets have a soft papery texture. The edible stems and the leaves have more flavor than the heart, but are similar to the heart in color. The

Received for publication 30 Sept. 1995. Accepted for publication 22 Oct. 1995. This research was supported in part by the U.S. Dept. of Agriculture under CSRS Special Grant no. 91-34135-6137, managed by the Pacific Basin Advisory Group (PBAG). This paper is no. 4170 in the Journal Series of the Hawaii Inst. of Tropical Agriculture and Human Resources. The cost of publishing this paper was defrayed in part by the payment of page charges. Under postal regulations, this paper therefore must be hereby marked advertisement solely to indicate this fact.

${ }^{1}$ Instituto Nacional de Pesquisas da Amazônia, Cx. Postal 478, 69011-920 Manaus, AM, Brazil. leaflets can be fanned into a delicate corrugated sheet (Fig. 1, right) or separated one from another. Some chefs were very enthusiastic about the combination of aesthetic value and culinary qualities of the leaf.

With three edible products from one stem, marketable yields are much higher than those of Latin American producers of canned heartof-palm. This feature provides the economic incentive that the Hawaiian farmer needs to develop a local heart-of-palm industry. The first two years of results from the Univ. of Hawaii's research and development program on pejibaye for heart-of-palm, reported earlier by Cavaletto et al. (1994), Clement and Manshardt (1994a, 1994b), and DeFrank and Clement (1994a, 1994b), are presented here in greater detail.

\section{EFFECT OF PLANTING DENSITY ON YIELD}

Two density $\times$ progeny trials were planted at Ninole, on the Hamakua Coast, Island of Hawaii, in Jan. and July 1991. The first trial contained nine open-pollinated progenies from the Yurimaguas population of the Pampa Hermosa landrace. The second contained nine open-pollinated progenies from the Benjamin Constant population of the Putumayo landrace. The experimental design was a replicated split-plot, with three planting densities as main plots [1.5 $\times 2 \mathrm{~m} \mathrm{(3333}$ plants/ha), $1 \times 2 \mathrm{~m}$ (5000 plants/ha, the commercial density in Costa Rica), $1 \times 1.5 \mathrm{~m}$ (6666 plants/ha)] and progenies as subplots, with nine plants per plot. The 1990-91 El Niño event caused an extended drought and consequent high mortality in the Yurimaguas experiment; therefore, discussion concentrates on the Benjamin Constant experiment.

Harvest started at 15 months after planting, and 4 months later, $28 \%$ of the plants had been harvested (Table 1). Mean heart diameters, lengths, and weights were not affected by plant density (Table 1). This

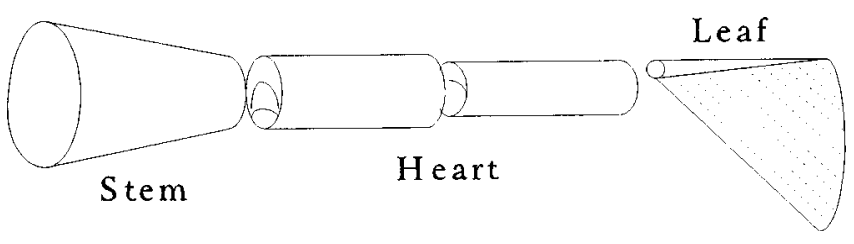

Fig. 1. The edible portions of a single palm shoot. The apical meristem is at the interface between the stem and the heart. The heart is 10 to $50 \mathrm{~cm}$ long, 2 to $5 \mathrm{~cm}$ in diameter, and weighs 50 to $300 \mathrm{~g}$. The stem is 10 to $20 \mathrm{~cm}$ long, 2 to $5 \mathrm{~cm}$ in diameter at the apex, and weighs 100 to $800 \mathrm{~g}$. The amount of leaf ranges from 30 to $150 \mathrm{~g}$, depending on heart length. 
Table 1. Effect of planting density on Benjamin Constant pejibaye (means for seven progenies) in Hawaii during the first 4 months of harvest (15 to 19 months after field planting).

\begin{tabular}{lcccc}
\hline \hline $\begin{array}{l}\text { Planting } \\
\text { density } \\
\text { (plants/ha) }\end{array}$ & $\begin{array}{c}\text { Plants } \\
\text { harvested } \\
(\%)\end{array}$ & $\begin{array}{c}\text { Diam } \\
(\mathrm{mm})\end{array}$ & $\begin{array}{c}\text { Length } \\
(\mathrm{cm})\end{array}$ & $\begin{array}{c}\text { Wt } \\
(\mathrm{g})\end{array}$ \\
\hline 3333 & 24.9 & $31.6 \pm 3.4$ & $24.2 \pm 6.7$ & $199 \pm 51$ \\
5000 & 34.4 & $31.6 \pm 3.8$ & $23.5 \pm 7.2$ & $190 \pm 53$ \\
6666 & 24.3 & $32.2 \pm 3.3$ & $24.3 \pm 7.3$ & $203 \pm 53$ \\
Mean & 27.9 & $31.7 \pm 3.5$ & $23.9 \pm 7.1$ & $196 \pm 53$ \\
\hline
\end{tabular}

relative uniformity was unexpected, as density affected all of these yield components in earlier experiments in Latin America. Increased density resulted in fewer harvestable plants during a given period in Costa Rica (Zamora, 1985) and produced thinner and lighter, but longer, hearts in Brazil (Moreira Gomes et al., 1988). The main reasons for lack of density effects in Hawaii were probably small plot size and canopy irregularity, the latter caused by significantly different growth rates among and within progenies. Canopy irregularity became even more pronounced following the beginning of harvest. Nevertheless, length and weight of the hearts were unaffected by plant density.

Actual heart-of-palm yields during the 4 months differed significantly among the three planting densities (Fig. 2). Potential heart-ofpalm yields (assuming all plants were harvested within the year) were similar to yields reported from Costa Rica. Yield of edible stem was much larger than that of heart-of-palm and potentially will provide an extra return for the farmer.

\section{GENETIC VARIABILITY FOR YIELD}

Test plantings of pejibaye were established at Ninole on the Hamakua Coast and at Waiakea in South Hilo, both on the Island of
Hawaii, and at Poamoho on the Island of Oahu. At each location, nine open-pollinated progenies from the Benjamin Constant population were planted in a randomized complete block, with nine plants per plot and at a density of 5000 plants/ha. The Ninole site received $3500 \mathrm{~mm}$ rainfall per year on an Alfisol, the Waiakea site received $4800 \mathrm{~mm} / \mathrm{year}$ on a Histosol, and the Poamoho site received $1100 \mathrm{~mm} / \mathrm{year}$ on an Oxisol, and was furrow-irrigated on an "as needed" basis.

At Ninole (the best site), harvest started at 15 months after planting, at Poamoho (an intermediate site) at 16 months, and at Waiakea (the poorest site) at 18 months. During the first 4 months of harvest at Ninole, $28 \%$ of the plants were cut, compared to $15 \%$ of plants during the first 3 months of harvest at Poamoho, and only $1 \%$ during the first cut at Waiakea (data not presented).

Progeny harvest percentages at 19 months were significantly different and ranged from $7 \%$ to $54 \%$ at Ninole, with three progenies above average (B-1, B-0, and B-9) (Table 2). Progeny harvest percentages also were significantly different at Poamoho and ranged from $4 \%$ to $48 \%$, with two progenies above average (B-3 and B-8). These five progenies were considered to be precocious at their respective sites and highlight the existence of significant genetic $\times$ environment interactions. They all produced average-sized hearts, but their precocity would provide early returns for the farmer. Precocity in pejibaye is essentially rapid vegetative growth; consequently, growth analysis provides further information about this germplasm (Clement, 1995).

\section{RESPONSE TO HERBICIDES AND POLYPROPYLENE MAT}

Yields and weed control were evaluated in response to 3,5-dinitro$N^{4}, N^{4}$-dipropylsulfanilamide (oryzalin) $(4.5$ and $9.0 \mathrm{~kg}$ a.i./ha), 2chloro-1-(3-ethoxy-4-nitrophenoxy)-4-(trifluoromethyl) benzene (oxyfluorfen) (0.6 and 1.2 kg a.i./ha), 1,1'-dimethyl-4,4'-bipyridinium

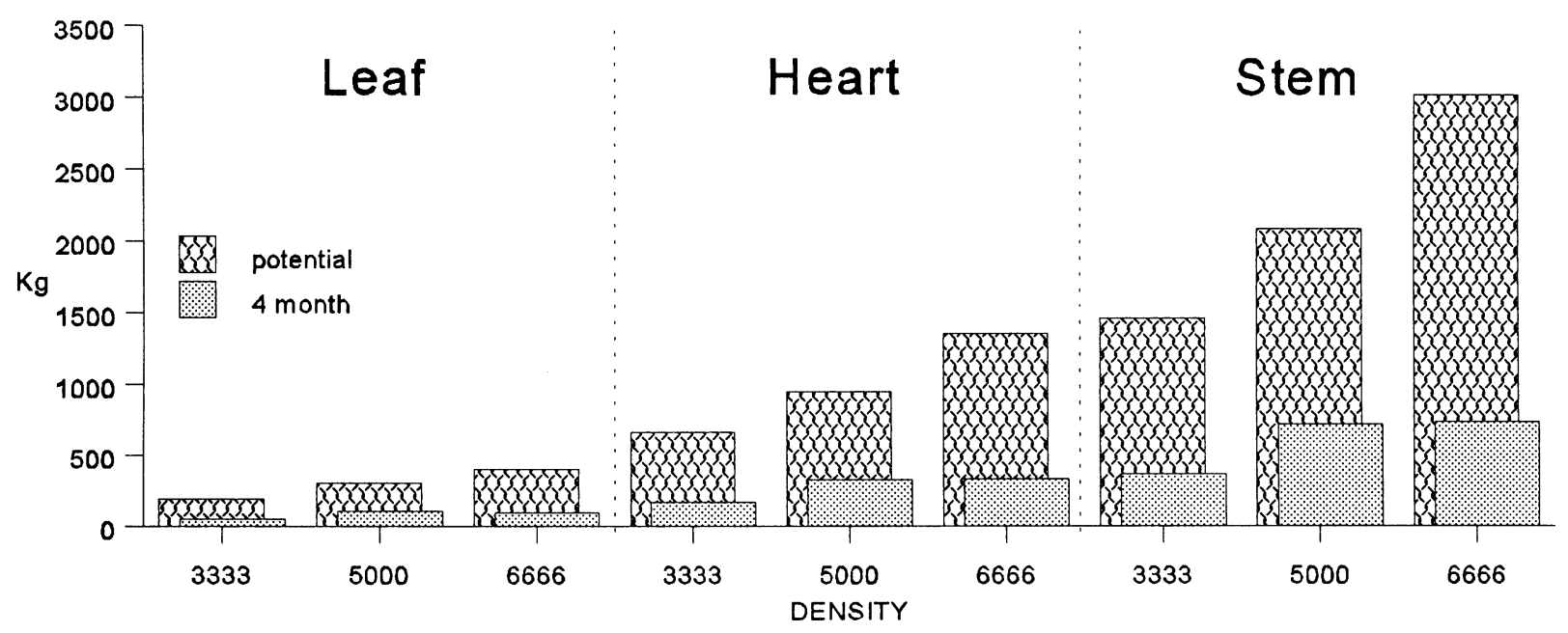

Fig. 2. Potential and 4-month yields $\left(\mathrm{kg} \cdot \mathrm{ha}^{-1}\right)$ of Benjamin Constant pejibaye in Hawaii. Potential yields assume that all plants are harvested within 12 months and that mean heart weights do not change over time.

Table 2. Variation in percentage of plants harvested after 19 months in the field and mean weights ( \pm SD) for heart-of-palm and total edible product for nine Benjamin Constant pejibaye progenies grown at two planting sites in Hawaii.

\begin{tabular}{|c|c|c|c|c|c|c|}
\hline \multirow[b]{2}{*}{ Progeny } & \multicolumn{3}{|c|}{ Ninole site } & \multicolumn{3}{|c|}{ Poamoho site } \\
\hline & $\begin{array}{c}\text { Harvest } \\
(\%)\end{array}$ & $\begin{array}{l}\text { Heart wt } \\
(\mathrm{g})\end{array}$ & $\begin{array}{c}\text { Total wt } \\
(\mathrm{g})\end{array}$ & $\begin{array}{c}\text { Harvest } \\
(\%)\end{array}$ & $\begin{array}{l}\text { Heart wt } \\
(\mathrm{g})\end{array}$ & $\begin{array}{c}\text { Total wt } \\
(\mathrm{g})\end{array}$ \\
\hline B-0 & 46.9 & $201 \pm 53$ & $686 \pm 108$ & --- & --- & --- \\
\hline B-1 & 33.3 & $183 \pm 46$ & $630 \pm 90$ & 25.9 & $226 \pm 66$ & $740 \pm 169$ \\
\hline B-2 & 19.8 & $183 \pm 49$ & $663 \pm 118$ & 3.7 & $253^{z}$ & $555^{z}$ \\
\hline B-3 & 14.8 & $203 \pm 49$ & $714 \pm 162$ & 40.7 & $228 \pm 69$ & $774 \pm 171$ \\
\hline B-5 & 7.4 & $233 \pm 88$ & $777 \pm 162$ & 22.2 & $245 \pm 69$ & $824 \pm 170$ \\
\hline B-6 & 9.3 & $197 \pm 64$ & $691 \pm 86$ & 11.1 & $265 \pm 33$ & $859 \pm 72$ \\
\hline B-7 & 7.4 & $200 \pm 38$ & $731 \pm 81$ & -- & --- & --- \\
\hline B-8 & 18.5 & $195 \pm 61$ & $726 \pm 141$ & 48.1 & $231 \pm 58$ & $798 \pm 114$ \\
\hline B-9 & 54.3 & $198 \pm 44$ & $697 \pm 111$ & 14.3 & $270 \pm 16$ & $854 \pm 52$ \\
\hline Mean & 23.5 & $196 \pm 53$ & $688 \pm 122$ & 23.7 & $237 \pm 61$ & $789 \pm 151$ \\
\hline
\end{tabular}

${ }^{\mathrm{z}}$ Only one plant was harvested. 
dichloride (paraquat) (1.2 and $2.4 \mathrm{~kg}$ a.i./ha), and a woven black polypropylene mat. Four open-pollinated progenies from the Benjamin Constant population were used as replications in a randomized complete block, with five plants per plot, at Waimanalo, Island of Oahu. The soil was a Mollisol, receiving $<1500 \mathrm{~mm}$ of rainfall and supplemental overhead sprinkler irrigation. Paraquat was sprayed at 50-day intervals, while the preemergence herbicides were sprayed at 90-day intervals.

Harvest started at 18 months after field planting or 17 months after treatment initiation. The polypropylene mat yielded the highest percent harvest $(80 \%)$, followed by oxyfluorfen $(50 \%)$, paraquat $(20 \%)$, and oryzalin (12.5\%). There were replication (genotype) effects, suggesting variation in tolerance to paraquat and oryzalin. There were significant treatment differences. Estimated heart-of-palm and total edible yields (3731 plants/ha), corrected for percent harvest, were highest with polypropylene mat, followed by oxyfluorfen 1.2 a.i. and 0.6 a.i. (Fig. 3). Paraquat severely inhibited growth of treated suckers on which future harvests depend (data not shown). The performance rating of these weed control treatments was mat $\approx$ oxyfluorfen $>$ oryzalin > paraquat (see DeFrank and Clement, 1995).

\section{RESPONSE TO GROUND COVERS}

Yields at 18 months and weed control were evaluated in response to ground covers of Arachis pintoi (Krapov. \& W. Gregory, nom. nudum.), Desmodium adscendens (Sw.) DC. (synonym D. ovalifolium Guillemin \& Perrottet), Chloris gayana (Kunth), and woven black polypropylene mat. Four open-pollinated progenies from the Benjamin Constant population were used as replications in a randomized complete block, with five plants per plot, at Waimanalo, Island of Oahu.

Overall, $25 \%$ of the plants had been harvested in the field by 18 months, with treatment means of $5 \%, 15 \%, 15 \%$, and $70 \%$, for $A$. pintoi, D. adscendens, C. gayana, and woven black polypropylene

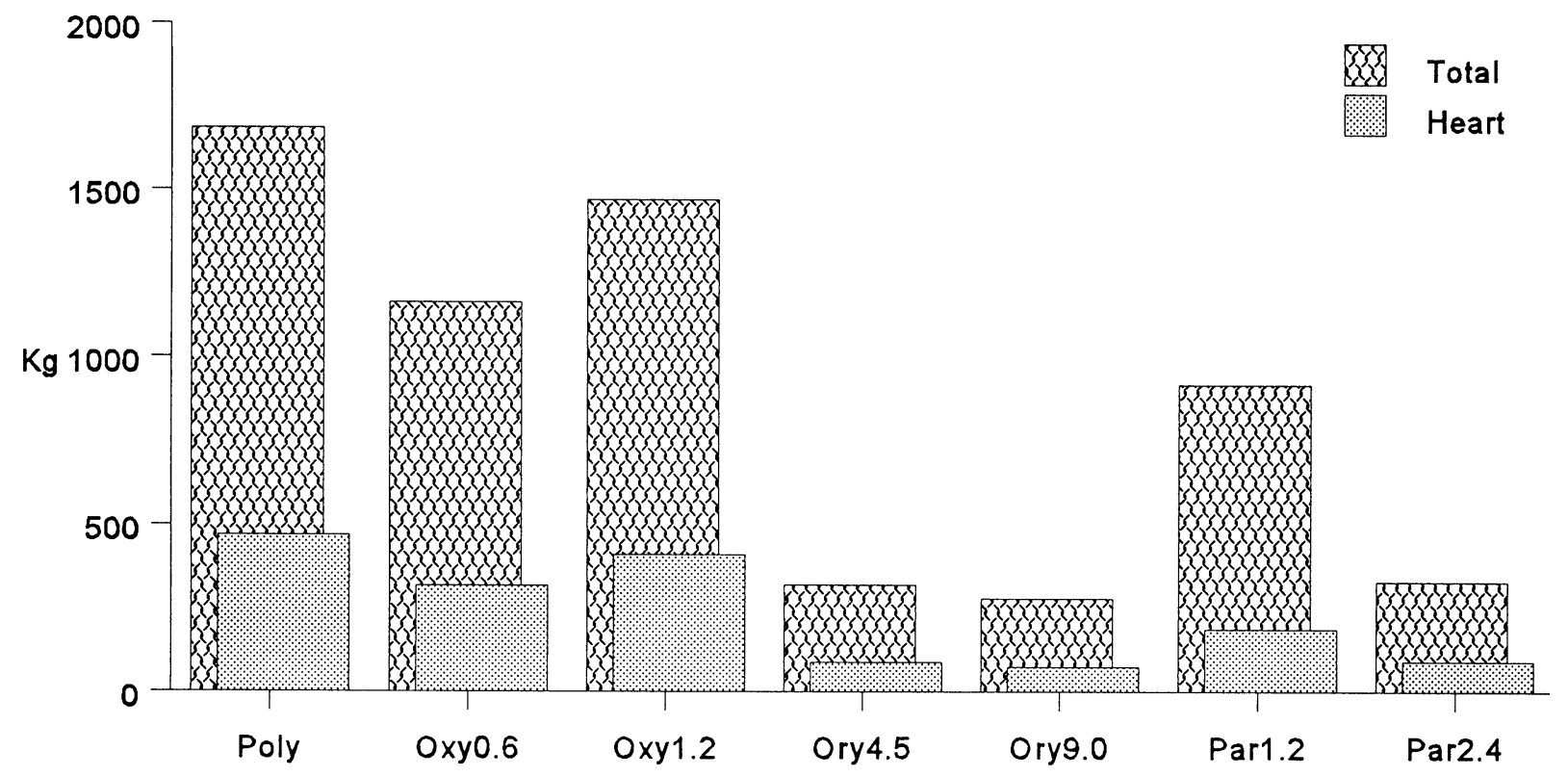

Fig. 3. Yielḋ $\left(\hat{\mathrm{kg}} \cdot \mathrm{ha}^{-1}\right)$ of Benjamin Constant pejibaye heart-of-palm and total edible product at 18 months in the field as influenced by weed control treatments consisting of polypropylene mat, oxyfluorfen ( 0.6 and $1.2 \mathrm{~kg}$ a.i./ha), oryzalin (4.5 and $9.0 \mathrm{~kg}$ a.i./ha), and paraquat (1.2 and $2.4 \mathrm{~kg}$ a.i./ha).

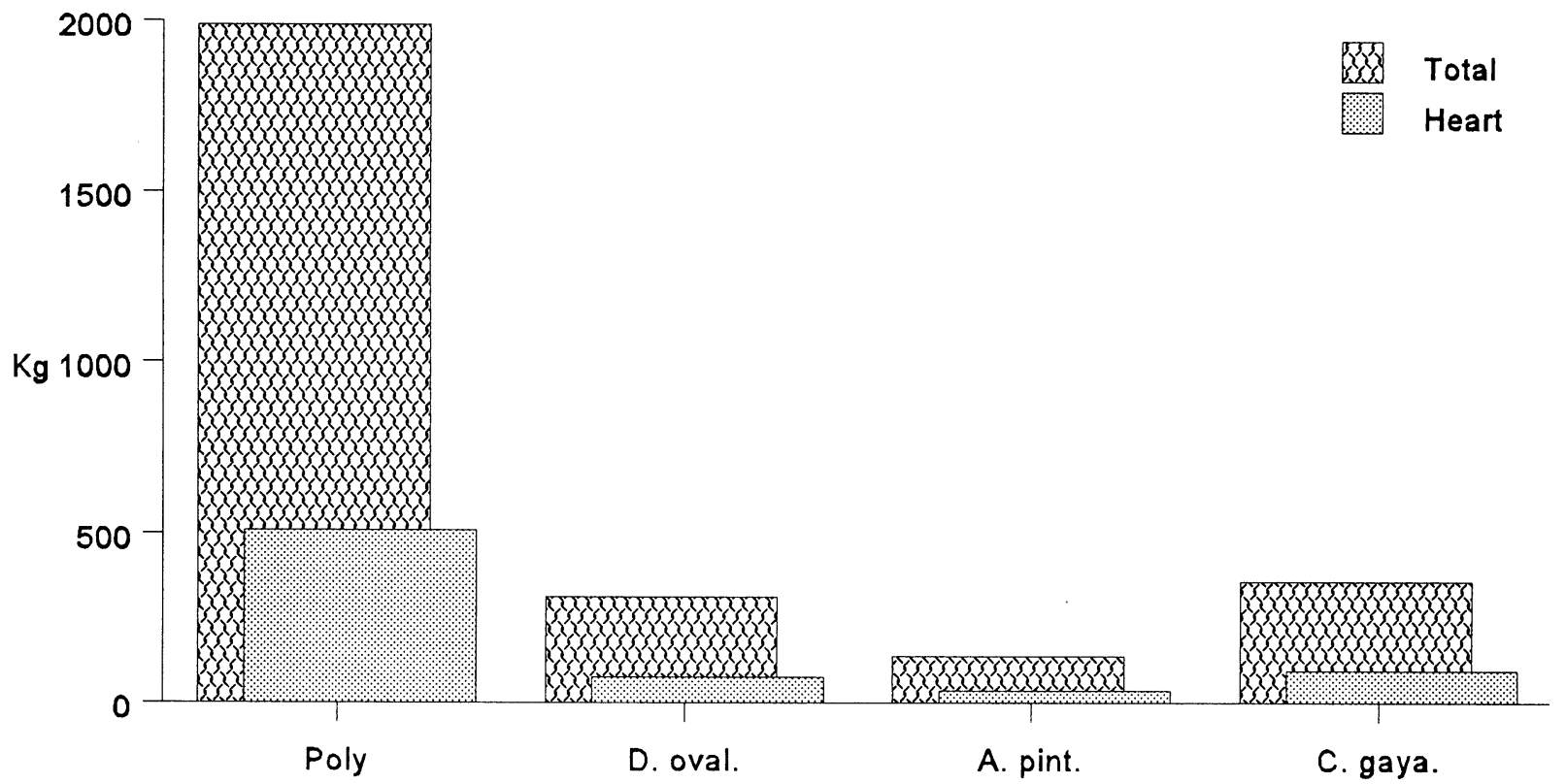

Fig. 4. Yields $\left(\mathrm{kg} \cdot \mathrm{ha}^{-1}\right)$ of Benjamin Constant pejibaye heart-of-palm and total edible product at 18 months in the field as affected by polypropylene mat, Desmodium adscendens, Arachis pintoi, and Chloris gayana ground covers. 
Table 3. Mean sensory scores for two Benjamin Constant pejibaye progenies and sensory score variation from successive segments of 9$\mathrm{cm}-$ long, heart-of-palm sections from the apical meristem (1st) to near the edible leaf (3rd). Mean scores represent 25 judgments on a scale of 1 to 5, with 1 lowest and 5 highest.

\begin{tabular}{|c|c|c|c|c|c|c|c|c|}
\hline \multirow[b]{2}{*}{ Descriptor } & \multicolumn{4}{|c|}{ Progeny B-3 } & \multicolumn{4}{|c|}{ Progeny B-8 } \\
\hline & Mean \pm SD & $1 \mathrm{st}$ & 2nd & $3 \mathrm{rd}$ & Mean \pm SD & $1 \mathrm{st}$ & 2nd & 3rd \\
\hline Sweetness & $2.1 \pm 0.3$ & 2.2 & 1.9 & 2.2 & $2.3 \pm 0.2$ & 2.6 & 2.1 & 2.1 \\
\hline Tenderness & $2.2 \pm 0.1$ & 2.3 & 2.0 & 2.4 & $2.5 \pm 0.2$ & 2.8 & 2.2 & 2.4 \\
\hline Crispness & $1.8 \pm 0.1$ & 2.0 & 1.8 & 1.8 & $2.1 \pm 0.3$ & 1.9 & 2.1 & 2.2 \\
\hline Moistness & $2.8 \pm 0.2$ & 2.7 & 2.6 & 3.0 & $2.9 \pm 0.1$ & 2.7 & 2.9 & 3.1 \\
\hline Astringency & $1.7 \pm 0.3$ & 1.9 & 1.5 & 1.7 & $1.5 \pm 0.1$ & 1.8 & 1.3 & 1.4 \\
\hline Acridity & $2.1 \pm 0.2$ & 2.2 & 2.2 & 2.0 & $1.9 \pm 0.3$ & 2.1 & 2.0 & 1.6 \\
\hline
\end{tabular}

mat, respectively. Individual heart-of-palm plant weights were similar for all treatments (mean $=169 \mathrm{~g}$ ). However, heart-of-palm and total edible yields differed significantly (Fig. 4).

All vegetative ground covers appeared to compete with pejibaye for nutrients, which probably explains the low harvest percentages and yields. Desmodium adscendens and C. gayana provided acceptable weed control because of good ground cover, but required more mowing. Arachis pintoi provided good ground cover and did not require much mowing, but resulted in poor weed control. Initial recommendations are to use the polypropylene mat close to the plants and either D. adscendens or $C$. gayana in the service rows.

\section{QUALITY EVALUATION OF FRESH HEART-OF-PALM}

Fresh pejibaye heart-of-palm samples from the Benjamin Constant and Yurimaguas populations were evaluated by taste panels. Favorable sensory characteristics included sweetness, tenderness, crispness, and moistness. Negative sensory characteristics found in some samples were astringency and acridity. Sensory scores for astringency and acridity were significantly different $(P<0.05)$ between sections of the heart. Basal sections (closer to the apical meristem) were more acrid and astringent than the apical sections (closer to the edible leaf) (Table 3 ). Differences in acridity also existed between plants within a progeny $(P<0.05)$. Total soluble solids ranged from $3.0 \%$ to $6.6 \%$, but no obvious pattern was apparent.

Chefs in upscale restaurants in Hawaii accepted samples with enthusiasm. Chefs can manage acrid samples by cutting to final form; soaking in warm, salted water for $30 \mathrm{~min}$; and rinsing before final use.

\section{CONCLUSIONS}

Our research shows that pejibaye is well adapted to at least two agricultural environments in Hawaii. With the demise of sugarcane production, large acreages in both of these ecological zones are now becoming available for new agricultural ventures. The preliminary results reported here show that pejibaye has the potential to become a new commercial crop in Hawaii, because the market will accept the product readily when it becomes available. Furthermore, our introduction program is providing the information that the farmer needs to get started. Both the Yurimaguas and the Benjamin Constant populations are well adapted to Hawaii. The former appears to grow somewhat better than the latter, but establishment difficulties did not permit a rigorous comparison. Planting densities between 5000 and 7000 plants/ha likely will give the best returns to the farmer without sacrificing yield. Unlike the uniformly spaced stands used in Latin American plantings, the plantation geometry in Hawaii will be in double rows. Vegetative ground covers in service lanes, between the crop double rows, will provide mechanical access and erosion control. Herbicide use will be minimized by employing a combination of polypropylene mat and vegetative ground covers, while oxyfluorfen can be used during field establishment without damaging the plants. With three edible products and chef enthusiasm for all of them, the growers' income should exceed costs by a significant percentage.

\section{Literature Cited}

Cavaletto, C.G., N.Y. Nagai, C.R. Clement, and R.M. Manshardt. 1994. Quality evaluation of fresh pejibaye palm heart (Bactris gasipaes). HortScience 29:537.

Clement, C.R. 1995. Growth and genetic analysis of pejibaye (Bactris gasipaes Kunth, Palmae) in Hawaii. PhD Diss., Univ. of Hawaii, Honolulu.

Clement, C.R. and R.M. Manshardt. 1994a. Genetic variability for precocious palm heart yield of pejibaye in Hawaii. HortScience 29:469-470.

Clement, C.R. and R.M. Manshardt. 1994b. Effect of planting density on precocious palm heart yield of pejibaye in Hawaii. HortScience 29:486487.

Clement, C.R., R.M. Manshardt, J. DeFrank, F. Zee, and P. Ito. 1993. Introduction and evaluation of pejibaye (Bactris gasipaes) for palm heart production in Hawaii, p. 465-472. In: J. Janick and J.E. Simon (eds.). New crops. Wiley, New York.

DeFrank, J. and C.R. Clement. 1994a. Response of pejibaye to herbicides and black polypropylene mat during establishment in Hawaii. HortScience 29:508.

DeFrank, J. and C.R. Clement. 1994b. Precocious response of pejibaye to legume, grass and black polypropylene ground covers during establishment in Hawaii. HortScience 29:509.

DeFrank, J. and C.R. Clement. 1995. Weed control in pejibaye heart of palm plantations in Hawaii. HortScience 30:1215-1216.

Mora Urpí, J., A. Bonilla, C.R. Clement, and D.V. Johnson. 1991. Mercado internacional de palmito y futuro de la explotación salvaje vs cultivado. Buletin Pejibaye (Guilielma) 3(1-2):627.

Moreira Gomes, J.B., J.M.T. Menezes, and P. Viana Filho. 1988. Efeito de níveis de adubação e espaçamento na produção de palmito de pupunheira (Bactris gasipaes H.B.K.) em solo de baixa fertilidade na região de Ouro Preto D'Oeste, Rondônia. In: Anais do $1^{\circ}$ Encontro Nacional de Pesquisadores em Palmito. Centro Nacional de Pesquisa de Florestas EMBRAPA, Curitiba. p. 261-266.

Torres, V.A. 1992. The U.S. market for palm hearts: An introductory study. MS Thesis, Cornell Univ., Ithaca, N.Y.

Zamora F., C. 1985. Densidades de siembra de pejibaye para palmito con tallo simple. In: Sexto Informe de Labores de Diversificación Agrícola 19831984. Asociación Bananera Nacional, San José, Costa Rica, p. 75-78. 


\title{
Ebenus cretica L., An Attractive Endemic Plant of Crete with Potential for Floricultural Use
}

\author{
J.C. Vlahos \\ Department of Horticulture, School of Agricultural Technology, Technological Educational Institute, 71500 \\ Iraklion, Crete, Greece
}

The introduction of new plants in floriculture and ornamental horticulture is an important development that has occurred in countries where agricultural research is well developed. For this reason, native plants are sought and selected for their desirable characteristics. In addition, they are studied in order to develop the best method for their production. Very often, the genetic improvement of native plants produces vigorous and disease-free plants for general cultivation. Growers are continually faced with strong competition and are willing to try new species only if this ensures them both better and less expensive production and, thus, greater profits. For some time now, Germany, Denmark, The Netherlands, and the United States have been involved with the introduction of new crop plants in the floricultural market because consumers are attracted by new products; thus, market trade has increased. Most of these new plants have originated in Australia, South Africa, and Latin American countries (Lentjies et al., 1985).

The island of Crete has 1750 native plant species and is considered one of the richest areas of the Mediterranean in variety and number of endemic plants as a result of the island's historical geography. This plenitude is clear from the fact that, in Europe, there are 2.5 native species of plants $/ 1000 \mathrm{~km}^{2}$, in Greece there are 42 , while Crete alone has 210 species. Among these species of flora on the island are plants that could, with relevant research, be cultivated and used in commercial horticulture. Some attempts to grow and develop several interesting native ornamental plants have taken place in Greece. In the Dept. of Horticulture at the Technological Educational Institute (TEI) of Iraklion, a research program was initiated in 1992 to investigate Ebenus cretica as a potential new flower crop. Ebenus cretica is an endemic plant, which, according to preliminary research findings from TEI of Iraklion, appears to have good possibilities for developing into a new floricultural crop.

\section{ORIGIN}

The genus Ebenus belongs to the family Leguminosae or Papilionaceae and it includes 18 species that grow in a wide area from the eastern Mediterranean to Central Asia (Huxley et al., 1992). Plants of this genus also can be found in areas of Algeria, Tunisia, Libya, and Egypt. Two species of Ebenus, E. cretica and E. sibthorpii DC, are endemic to Greece. Ebenus sibthorpii flourishes in most rocky areas of Thessaly in mainland Greece and on the island of Euboia. Ebenus cretica is encountered exclusively in Crete (Huxley and Taylor, 1977; Polunin, 1988; Turland et al., 1993) and grows in many areas of the island, but mostly in the center and south (Fig. 1). The name probably derives from Hippocrates (460-377 BC) who used the name Ebenus for all legumes. Linnaeus, in his Species Plantarum, referred to it as Ebenus creticus L., while today its name is attributed to Prosper Alpinus. This name was finally bestowed by Bentham-Hooker in Genera Plantarum. It also was referred to by the name Anthyllis cretica Willd. In Crete, it is mostly known as "poupoulo" (featherdown), but other names also are used, depending on the region of the island. In English, it is called "Cretan Silver Bush" and in French "L'ebenier de Crete." However, E. cretica must not be confused with Diospyros ebenum Koenig ex Retz., the tree that produces ebony.

Received for publication 30 Sept. 1995. Accepted for publication 22 Oct. 1995. The cost of publishing this paper was defrayed in part by the payment of page charges. Under postal regulations, this paper therefore must be hereby marked advertisement solely to indicate this fact.
The plant has been known in western Europe since 1737 and has been cultivated in the Royal Botanical Gardens at Kew in England since 1748. It was listed in all the European botanical gardens and was referred to as a greenhouse plant. From 1677 to 1850 , it was mentioned in certain European horticultural catalogs as a plant for the greenhouse and was recorded as existing in the gardens of English nobles in London and Bristol. Records show that it was grown in the gardens of Trianon at Versailles in 1850 and in the Villa Thuret (Jardin d' Antibes) in France in 1885. In 1868, it was found in the greenhouses of Charles Huber at Hyères. These greenhouses were well known for their collection of new and rare plant species. In Revue Horticole, the cultivation of E. cretica in an open, protected area in the region of Paris in 1901 is mentioned, and it is stressed that this is a hardy plant, which survived through the winter and flowered with small pink flowers in the summer (Andre, 1902).

Today E. cretica can be found in two small nurseries in England (Old Manor Nursery in Gloucestershire and T. Ingra at Canterbury in Kent) as well as in other minor amateur nurseries in France (Cote d' Azur, Provence). Additionally, it has been reported that some botanical gardens in the United States carry E. cretica. In Greece, the Museum of Natural History keeps certain species of Ebenus in its gardens at Kifissia, near Athens.

\section{DESCRIPTION}

Plants of E. cretica are small, herbaceous perennial evergreen subshrubs up to $60 \mathrm{~cm}$ tall (Fig. 2). New growth is finely pubescent. Leaves are alternate and consist of 3 to 11 leaflets 1 to $3 \mathrm{~cm}$ long and 4 to $6 \mathrm{~mm}$ wide. Leaflets are oblanceolate-shaped with pointed tips. Flowers are vivid pink or porphyry (purple) and they form thick racemes that develop from axillary buds, while the shoot tips remain vegetative. Racemes are elongated and cylindrical with a small pedicel and they vary in length from 5 to $20 \mathrm{~cm}$. Flower buds are covered in silvery down and are very attractive even before opening (Sficas, 1987). Flowers are zygomorphic, like all other species in Leguminosae, and the corolla encircles the stamens and the pistil; the banner is almost equal to the wing. The calyx is tubular-campanulate with five equalsized sepals (Heywood and Ball, 1968). Color variants in E. cretica are very rare. Recently, however, in the area of Ierapetra, in the southern coast of Crete, plants with white flowers were found, while in our collection at TEI, some plants produced bichromatic-white and pink-flowers (Fig. 3). Fruit (a pod) is flattened, surrounded by the calyx, dehiscent, and usually contains one and, rarely, two seeds.

Ebenus plants in Greece flower from April to June, depending on altitude and area. Flowers become a yellow-brown toward the end of the flowering period. Not all the flowers form seeds, perhaps because E. cretica is not self-fertilized, which explains the presence of many

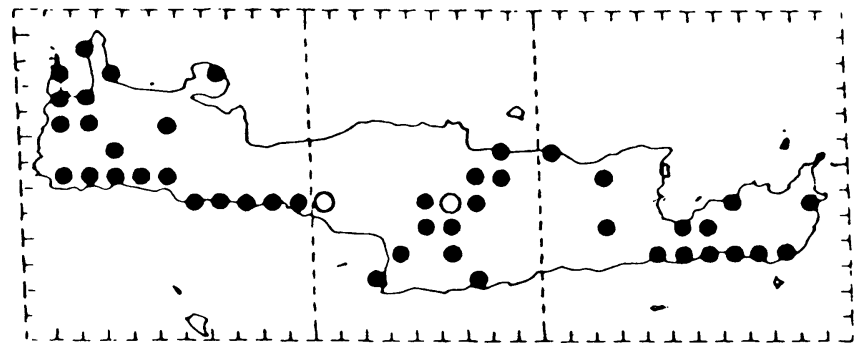

Fig. 1. Distribution of Ebenus cretica on the island of Crete (Turland et al., 1993). 


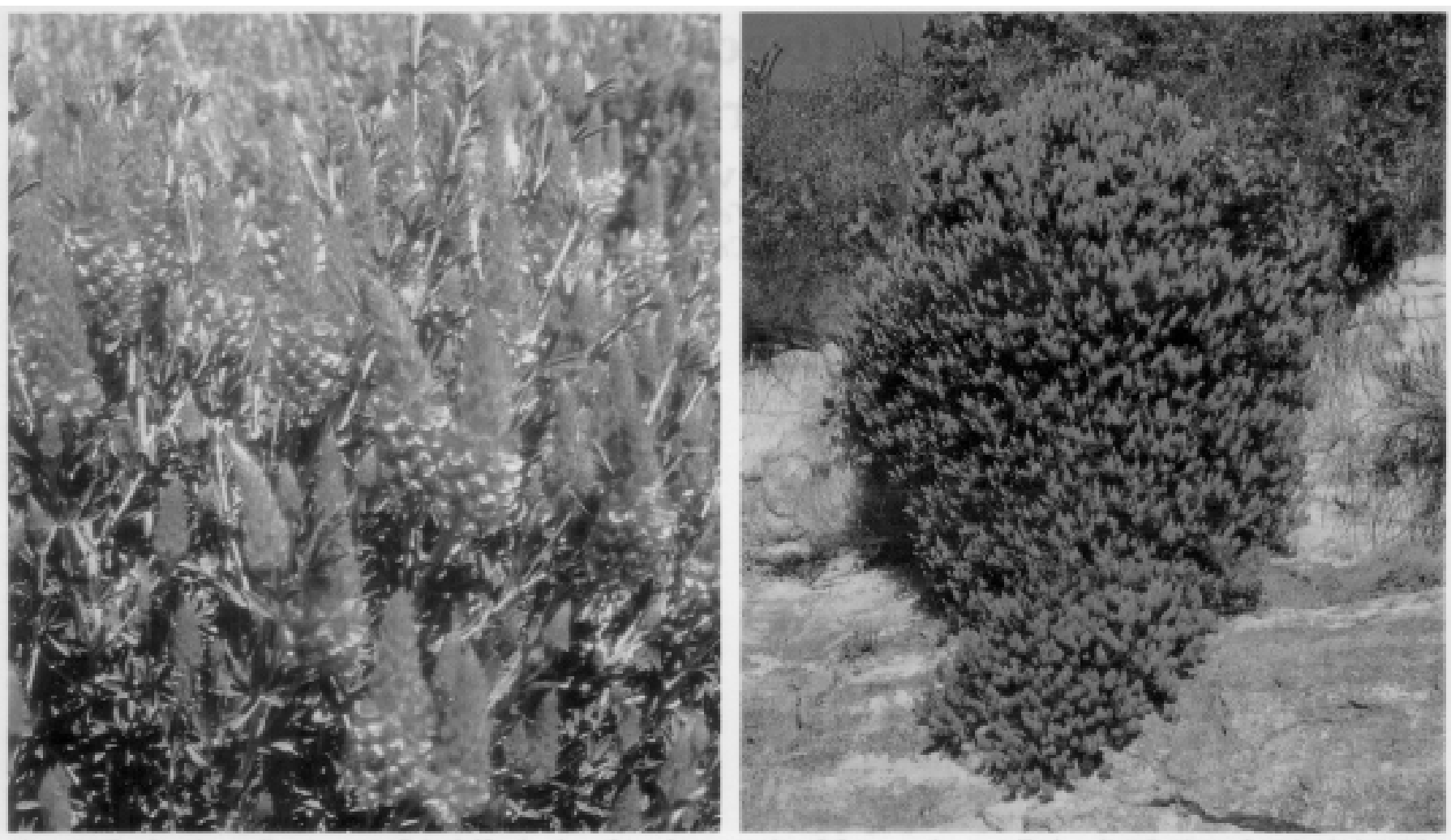

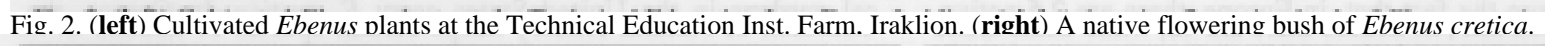

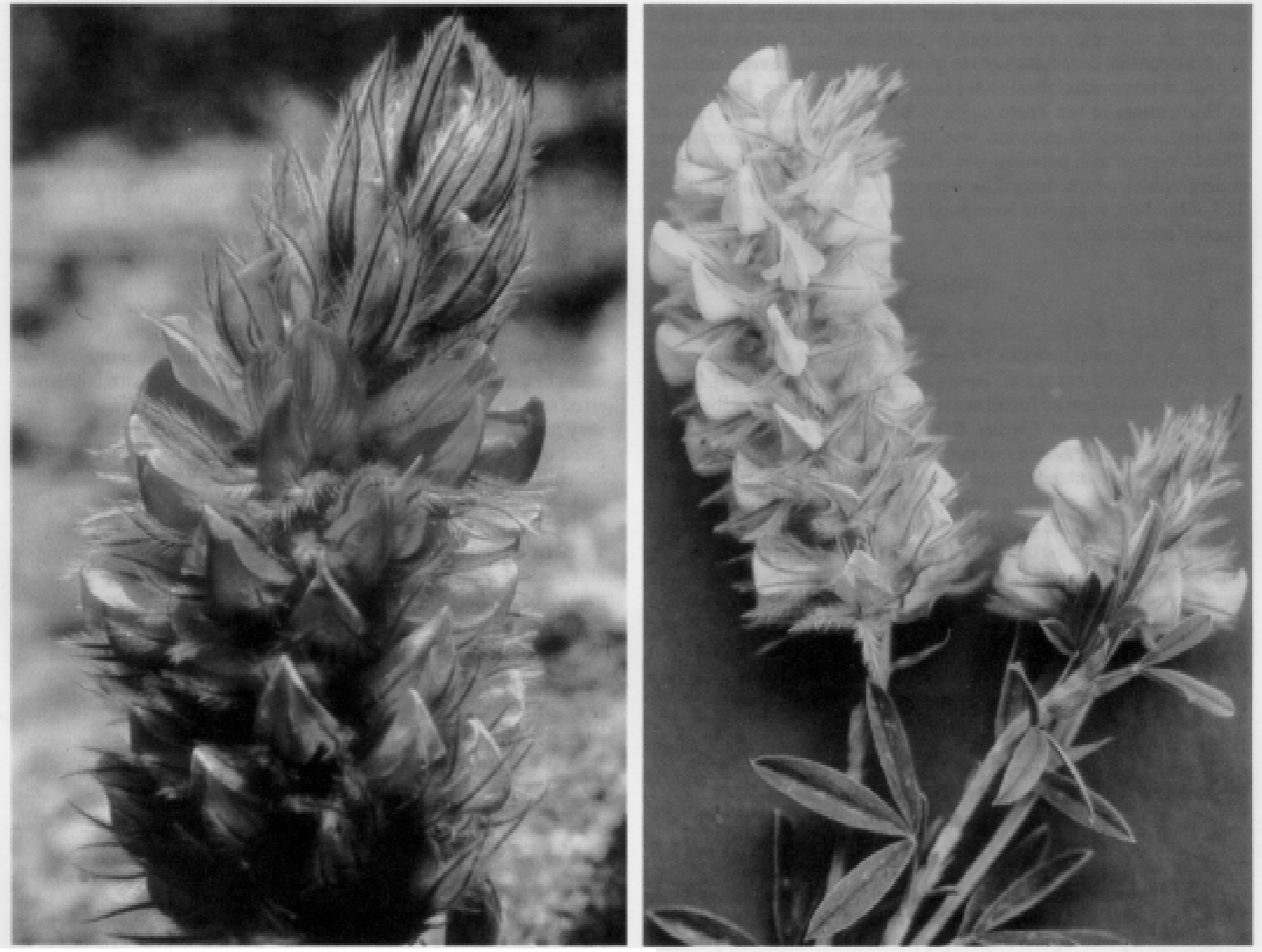

Fig. 3. Racemes of (left) red-flowered and (right) white-flowered Ebenus cretica. 


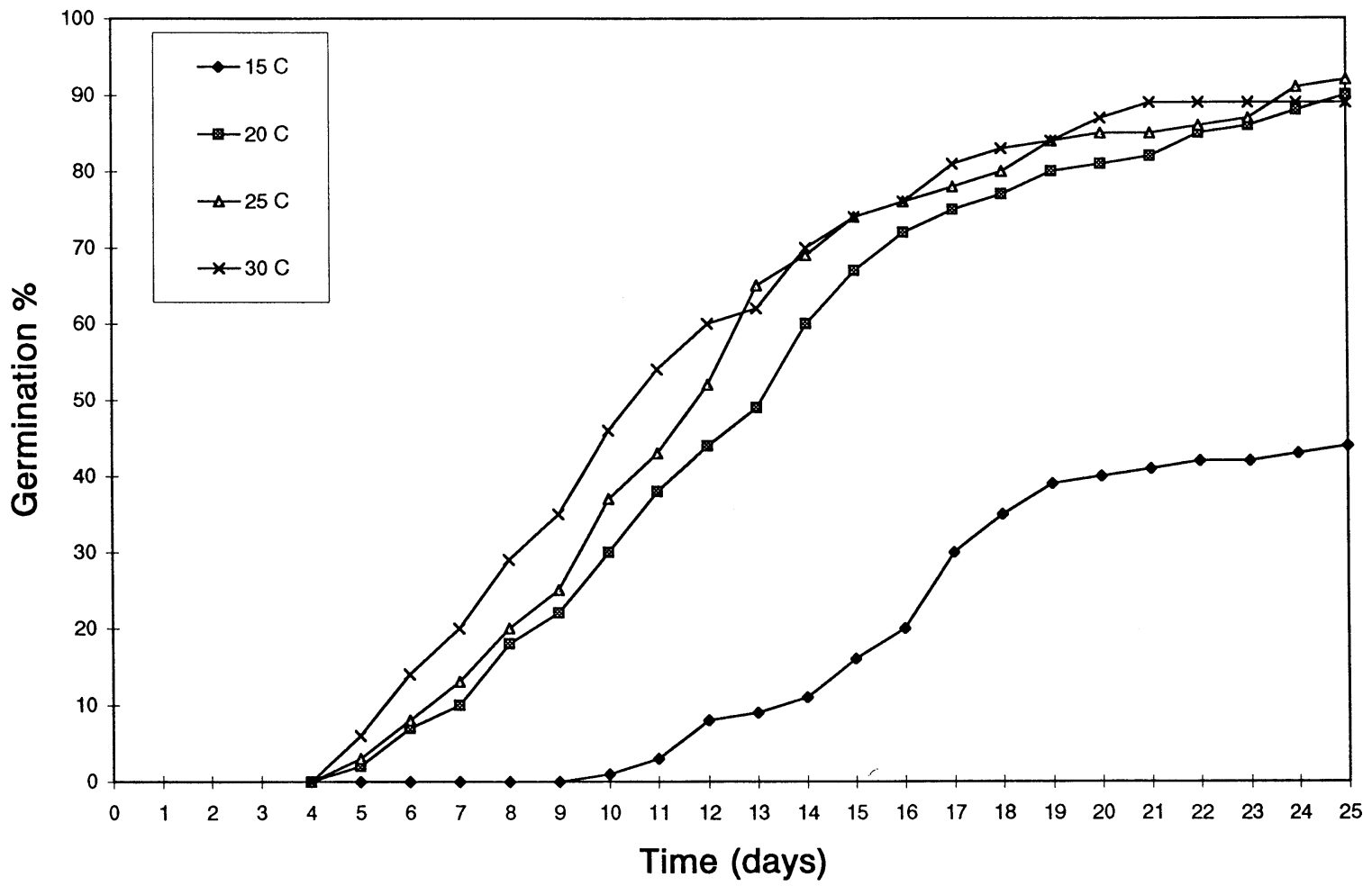

Fig. 4. Seed germination of Ebenus cretica. Seeds were sown in vitro on half-strength MS medium at 15, 20, 25, and 30C in light.

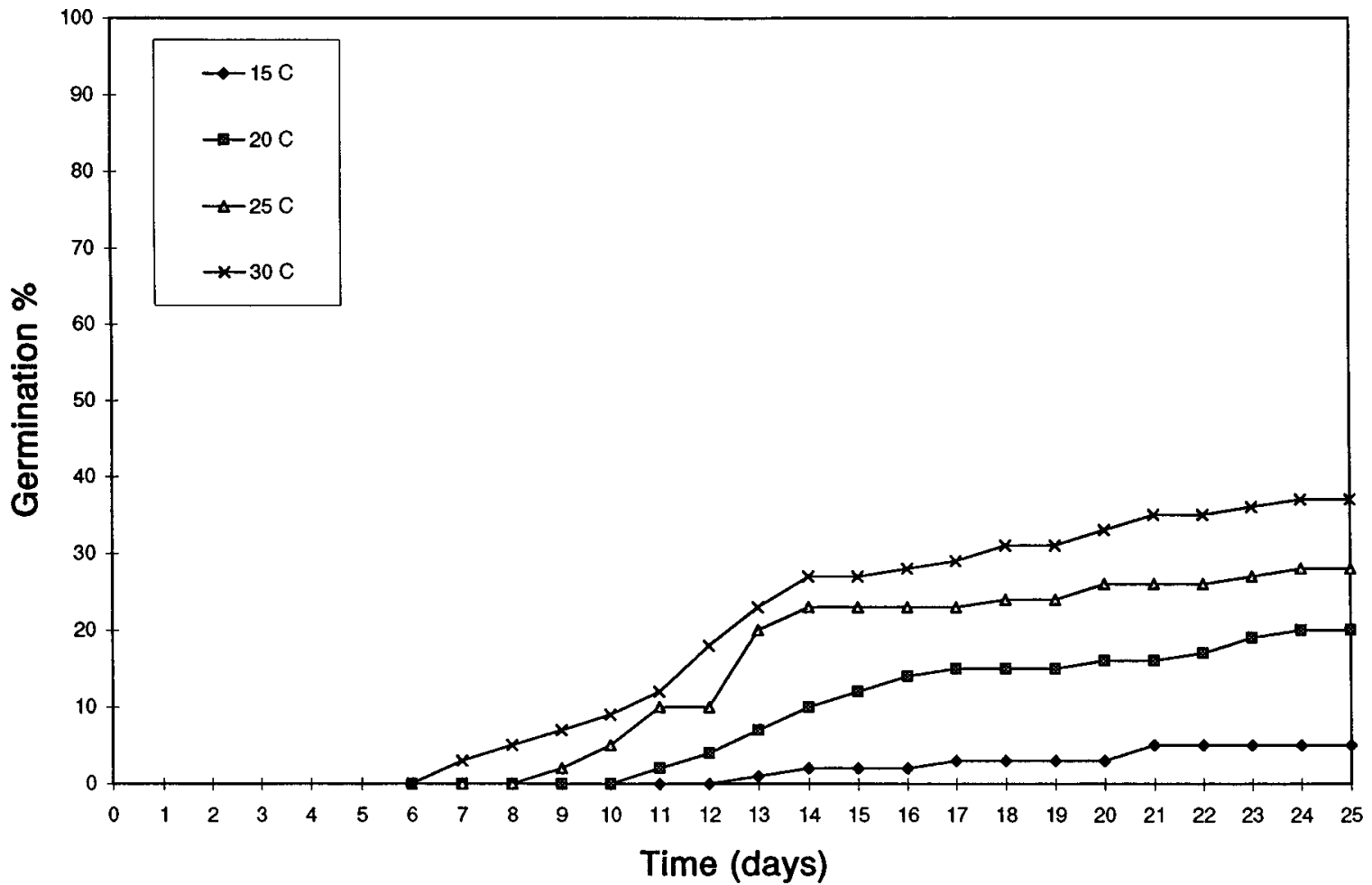

Fig. 5. Seed germination of Ebenus cretica. Seeds were sown in vitro on half-strength MS medium at 15, 20, 25, and 30C in darkness.

insects during the flowering period. Ebenus cretica grows in rocky areas of hills, at an altitude $<800 \mathrm{~m}$, in alkaline soil. Seeds, which fall from the mature fruit, sprout in the shade of the mother plant; thus, numerous plants grow in groups, creating a fantastic picture when all the plants develop flowers in the hills.

Ebenus cretica plants contain much starch, as evident in microscopic cross section of young stems; thus, it is a good food for sheep and goats. Every year, the plants are subjected either to intense grazing or their shoots are cut by farmers to feed rabbits; very often their dried flowers are collected for filling pillows.

\section{RESEARCH EFFORTS}

I first collected Ebenus seeds from the native plants on the island of Crete in July 1991. Ebenus seed germinated well in vivo and in vitro, with an average of $90 \%$ between 20 and 30C. The growing medium and soil type significantly influenced seed germination (unpublished results). Commercial potting mixtures proved more suitable for seed germination compared to other media. Germinability was considerably enhanced when seeds were large and well filled. Furthermore, the dry calyx coating the seeds has to be removed to prevent delays in seed 
germination. Seed germination and seedling emergence were not always uniform. Half-strength Murashige and Skoog (MS) medium with pH 6.0 under light at 20,25, and 30C improved germination in vitro. Median germination (50\% of seeds) was achieved in 10 days at higher temperatures in light (Fig. 4), while the germination percentage was reduced considerably in darkness (Fig. 5).

The resulting seedlings were either planted in $15-\mathrm{cm}$ pots $(2.4$ liters) or in the ground in June 1992. These seedling plants grew and flowered normally in May through June of the next year. Marked differences were observed in growth and flowering of Ebenus cretica seedlings planted in the ground and in those in pots. Plants in pots were
$35 \mathrm{~cm}$ tall and had seven flowers per plant compared to those plants grown in the ground that were $90 \mathrm{~cm}$ tall and had 138 flowers per plant. Following the end of the flowering season in June through July, plants in the ground were pruned (severely, moderately, or not at all) to test the effect of pruning on the development of side shoots, since the Ebenus plants have a tendency to develop side shoots without a strong influence of apical dominance. The severe or moderate pruning gave the best results-vigorous new growth. In the following year, more investigations were conducted using different types of soil mixtures (peat, compost, natural lime soil) and two types and sizes of pots (clay or plastic) to determine the best conditions for growing Ebenus plants.

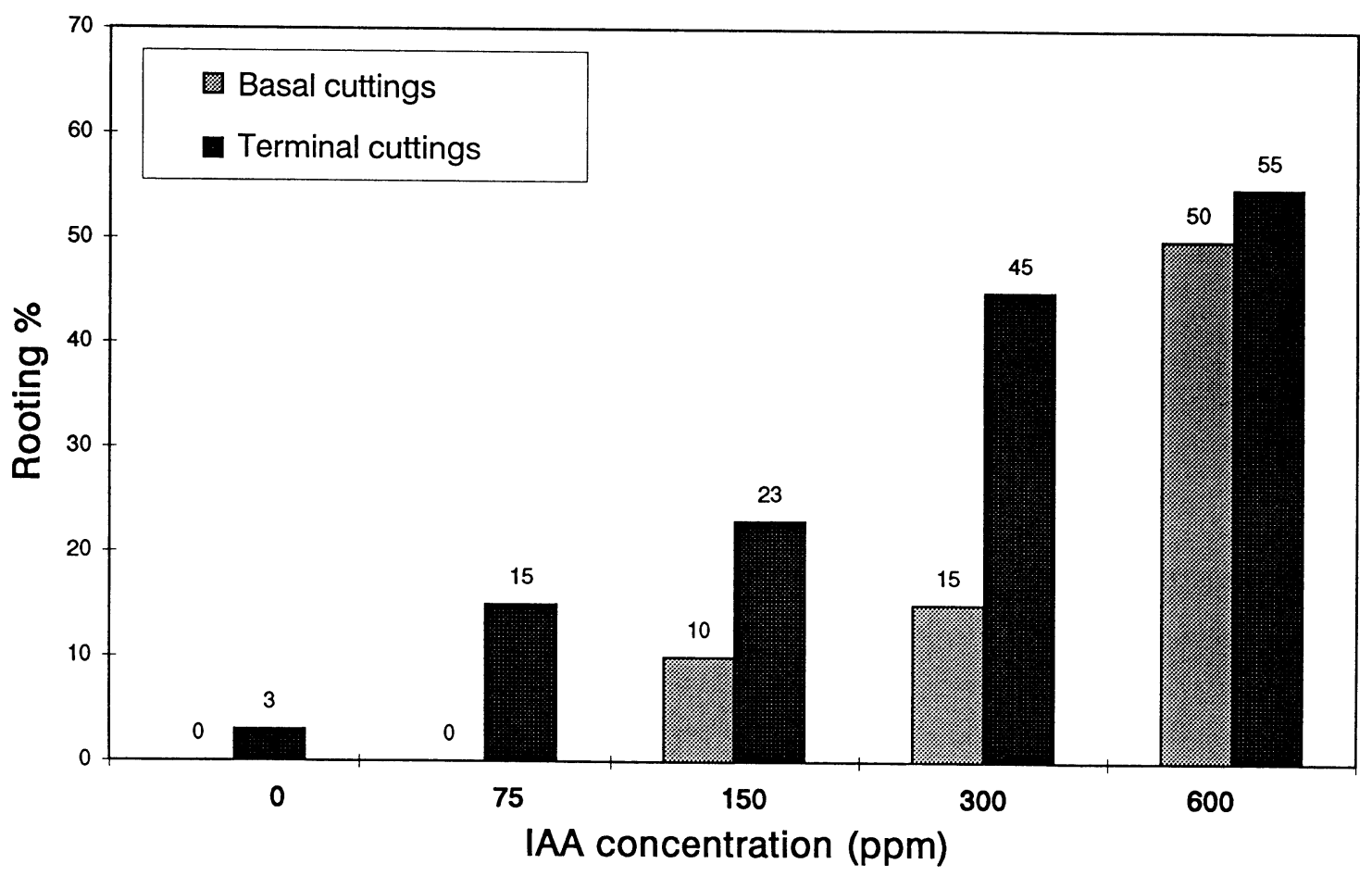

Fig. 6. Effect of IAA concentrations on rooting Ebenus cretica. Terminal or basal cuttings were immersed in 0, 75, 150, 300, and 600 ppm aqueous solutions of IAA for $16 \mathrm{~h}$.

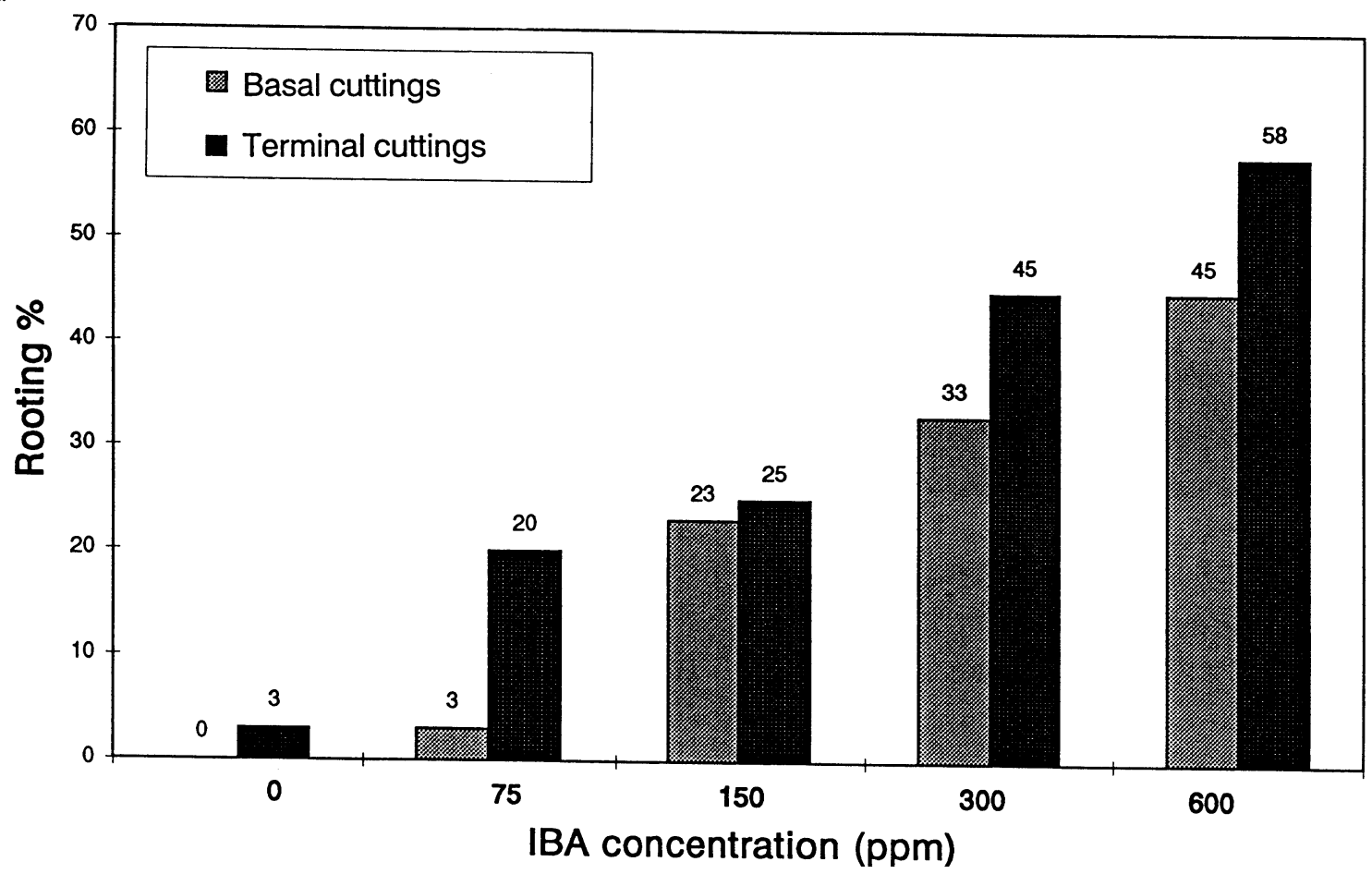

Fig. 7. Effect of IBA concentrations on rooting Ebenus cretica. Terminal or basal cuttings were immersed in 0, 75, 150, 300, and 600 ppm aqueous solutions of IBA for $16 \mathrm{~h}$. 


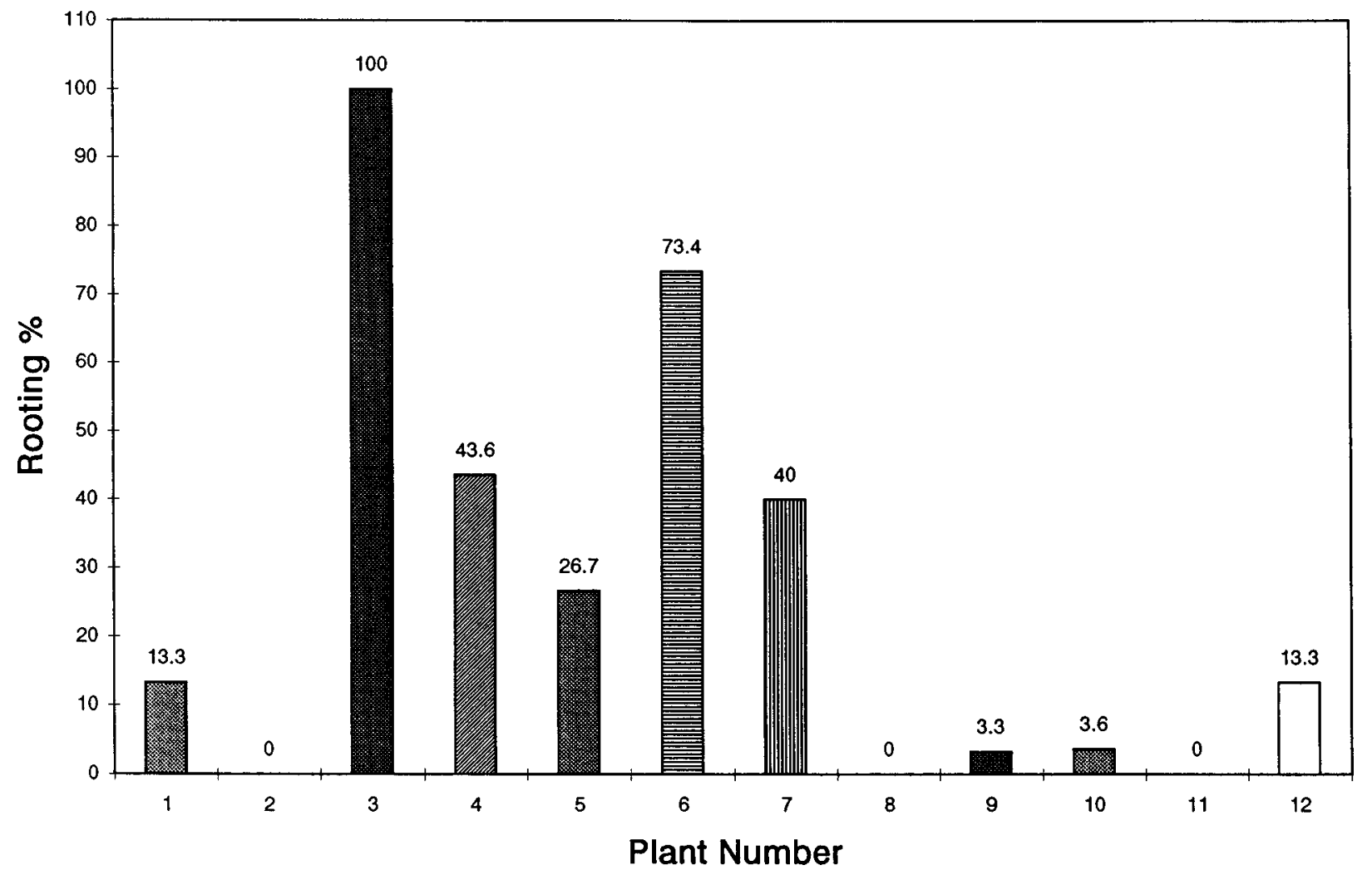

Fig. 8. Rooting percentage of terminal cuttings of Ebenus taken from 12 cultivated plants.

The commercial potting medium was found to be the least desirable for Ebenus. Growth and flowering were best when a 1 commercial potting compost : 1 natural soil mixture was used. The quality of the pots (clay or plastic) had no effect on the growth of Ebenus plants. However, the 12-liter pots improved growth and plants produced more flowers compared to those in the smaller pots (2.4 liters).

For the asexual propagation of Ebenus plants, experiments on rooting cuttings were carried out using several concentrations of auxins [indole acetic acid (IAA), indole-3-butyric acid (IBA), or naphthalene acetic acid (NAA)] on various kinds of plant materials used for cuttings (hardwood or softwood, terminal or basal portion of the stem, and cultivated or wild-type plants) in separate rooting media. The best results were obtained when softwood cuttings from terminal stems were immersed in IAA or IBA at $600 \mathrm{mg}^{-1 i t e \mathrm{r}^{-1}}$ for $16 \mathrm{~h}$ (Figs. 6 and 7). In any case, the average rooting percentage was rather low, since only $50 \%$ of cuttings rooted, and a still lower percentage survived and developed into normal plants.

The genetic makeup of plants used for cuttings also may affect rooting. From the collection of cultivated Ebenus plants at the TEI farm, several individual plants were selected based on their phenotypic characteristics, such as early flowering, vigor and type of growth, color and size of flowers, leaf color, etc. In cuttings taken from 12 individual plants and treated with a commercial rooting powder, rooting ranged from 0 to $100 \%$, depending on the mother plant (Fig. 8).

Experiments for in vitro micropropagation of Ebenus also were carried out. These investigations were aimed at the possibility of producing selected clones from specific individual plants that showed desirable characteristics. In this way, the production of identical plants in large quantities will be possible for commercial floricultural use. The sterilization of plant material taken either from the TEI farm or the countryside proved to be very difficult. Because the Ebenus leaves and shoots are covered with fine hair, sterilization with the commonly used methods was not a success. Therefore, seeds were germinated in vitro and subsequently shoot tip explants were taken and cultured in MS medium (half or full strength) supplemented with NAA auxin, 6benzylaminopurine (BAP) cytokinin, and $\mathrm{GA}_{3}$ gibberellin at various concentrations. In all of these cases, callus formed depending on the quantity of auxin used in the medium. After subculturing for 12 weeks, some explants developed roots. However, great diversity in phenotype was observed, which is probably attributable to explants originating from differing seed sources.

With the aim of using Ebenus as a cut flower, several experiments were conducted to investigate its keeping quality using various preservative solutions. Sucrose, calcium nitrate $\left[\mathrm{Ca}\left(\mathrm{NO}_{3}\right)_{2}\right]$, and 8hydroxyquiniline sulfate (HQS) were used as holding solutions. As pulsing solutions, silver thiosulfate (STS), $\mathrm{GA}_{3}$, and BAP were used in various combinations and concentrations. These preliminary experiments gave promising results; when $5 \% \mathrm{Ca}\left(\mathrm{NO}_{3}\right)_{2}$ in combination with HQS at $50 \mathrm{mg} \cdot \mathrm{liter}^{-1}$ was added to the holding solution, vase life was extended up to 9 days and a vivid flower color was preserved. Solutions containing sucrose shortened vase life, whereas the use of either $\mathrm{GA}_{3}$ or BAP did not affect keeping quality of Ebenus flowers. Additional studies are needed in this area before drawing final conclusions. Due to the nature of its inflorescence, Ebenus could be used very easily for dried flower arrangements.

\section{CONCLUSIONS}

From the experimental research conducted so far, the endemic plant Ebenus, with its attractive flowers and fine foliage, clearly has many possibilities for use in floriculture and ornamental landscaping. There are indications that the physiology of the plant and its morphological characteristics will establish it as a new attractive plant with a place in the flower markets of the European Union and the United States in the near future. It is certain, however, that additional research on the floral biology of Ebenus is needed regarding factors that regulate flower initiation and production. Cultural requirements, such as irrigation and fertilization or use of plant growth regulators, have not been fully investigated. There is no doubt, however, about its adaptability to a Mediterranean type of ecosystem, which makes it a perfect plant for the xerothermic regions of southern Europe or California and other areas in the United States with a similar climate.

Results obtained thus far indicate that there is a significant variation among the native population of Ebenus cretica on the island of Crete. The genetic diversity of the species makes it imperative that the 
best and the most suitable genotypes be selected based on the best characteristics for each use of the plant. Initiation of a systematic breeding project for developing novel flower colors, uniform plant material, and other desirable characteristics is required so that, following the process of selection, breeding, and evaluation, E. cretica could be marketed and become available to the public for a variety of floricultural uses.

\section{Literature Cited}

André, E. 1902. Ebenus creticus. La Revue Horticole. 74:160-161. Heywood, Y.H. and P.W. Ball. 1968. Leguminosae, p. 191. In: T.G. Tutin, Y.H. Heywood, N.A. Burges, D.M. Moore, D.H. Valentine, S.M. Walters, and
D.A. Webb (eds.). Flora Europaea. vol. II. Cambridge Univ. Press, Cambridge, U.K.

Huxley, A., M. Griffiths, and M. Levy (eds.). 1992. The new Royal Horticultural Society's dictionary of gardening. Macmillan, London. Stockton Press, New York. p. 1158.

Huxley, A. and W. Taylor. 1977. Flowers of Greece and the Aegean. Chatto and Windus, London. p. 186.

Lentjes, P., I. Laangland, and J. Eijsink. 1985. Eerste Toetsing van vaste planten als bloiende potplant. Vakblad voor de Bloemisterij. vol. I:33.

Polunin, O. 1988. Flowers of Greece and the Balkans: A field guide. Oxford Univ. Press, London. p. 312

Sficas, G. 1987. Wild flowers of Greece. Efstathiades Group SA, Athens.

Turland, N.J., J. Chilton, and J.R. Press. 1993. Flora of the Cretan area. Natural History Museum, London.

\title{
Ribes Production in North America: Past, Present, and Future
}

\author{
Danny L. Barney \\ University of Idaho Sandpoint Research and Extension Center, 2105 North Boyer, Sandpoint, ID 83864
}

\section{IMPORTANCE OF RIBES CROPS}

Herbalists collected Ribes fruit from the wild for use in medicines as early as the 1400s, and domestication efforts began during the $1500 \mathrm{~s}$. By the $1700 \mathrm{~s}$, red currants $(R$. rubrum L.) and gooseberries $(R$. uva-crispa L.) were popular garden fruits in western Europe and black currants $(R$. nigrum L.) were sold in farmers' markets in Russia.

Domestic currants and gooseberries were introduced into the United States in the 1700 s. By 1920 , there were $\approx 3000$ ha in commercial production (Hedrick, 1925). Most of the farms were concentrated in the middle Atlantic, upper Midwest, and northeastern states. New York was the leading state for currant production, followed by Michigan, Pennsylvania, Ohio, Minnesota, Missouri, Colorado, Washington, and California. Marin County, Ore., was the only county in the United States with more than 40 ha of commercial gooseberries. Fruit growers also produced gooseberries in Michigan, Washington, and Colorado (Shoemaker, 1948). Ontario produced about $50 \%$ of Canada's currant and gooseberry crops. British Columbia contributed $25 \%$ of the total, with the remainder produced in Quebec and Nova Scotia.

Red and white ( $R$. rubrum L.) currants made up nearly all of the Ribes production in the United States (Hedrick, 1925). Black currants were never popular in the United States. Shoemaker (1948) reported, however, that they made up about half of all Canadian Ribes production, with red currants and gooseberries each making up about $25 \%$.

The introduction of white pine blister rust (Cronartium ribicola Fisch) from Europe during the late 1800s and early 1900s on infected pine seedlings spelled the doom of the Ribes industry. Ribes, especially European black currants, are alternate hosts for the disease that attacks five-needled pines. Blister rust killed millions of pines throughout North America in the early 1900s. In 1933, with support from the U.S. government, many states prohibited the importation or cultivation of currants and gooseberries. Foresters even attempted to eradicate native Ribes from many forest lands.

In 1966, the U.S. government lifted restrictions on Ribes production, and many states followed suit. Today, only North Carolina and New Hampshire ban Ribes production, and 23 other states have less stringent restrictions. Canada has no restrictions on importing or growing currants and gooseberries. With the introduction of blister rust-resistant pines and currants, there is renewed interest in commer-

Received for publication 30 Sept. 1995. Accepted for publication 23 Oct. 1995. The cost of publishing this paper was defrayed in part by the payment of page charges. Under postal regulations, this paper therefore must be hereby marked advertisement solely to indicate this fact. cial and home production of currants, gooseberries, and jostaberries (R. nigridolaria Bauer) (currant-gooseberry hybrids).

As of 1994, there were about 80 to 160 ha of commercial gooseberries and currants in North America. Ribes production is a major industry in Europe. Brennan (1990) reported that Poland, Germany, and Hungary were the leading gooseberry producers, while British production has fallen because of decreased demand, increased production costs, and labor problems. The former Soviet Union also was a major gooseberry producer (Keep, 1975). Red and white currants are grown primarily in Poland and Germany, with lesser production in Belgium, Holland, France, and Britain (Brennan, 1990).

Black currants are the major Ribes crop grown worldwide. According to Brennan (1990), Britain produced nearly 3000 ha of black currants in 1988. Keep (1975) reported the former Soviet Union had nearly 60,000 ha of black currants in production in 1972, although much of that area may represent noncommercial home gardens. According to Brennan (1990), growers worldwide produced more than 588,000 t of currants and gooseberries in 1986. North America contributed only $45 \mathrm{t}$ to the total.

\section{ORIGIN AND BOTANY}

About 150 species of the genus Ribes are found throughout the northern portion of the Northern Hemisphere, along the Andes Mountains in South America, and in northwestern Africa along the Mediterranean (Brennan, 1990). Breeders have used $\approx 18$ species in developing modern cultivars (Harmat et al., 1990). Besides several ornamental species, five Ribes types are grown for their fruit: black currants, red currants, white currants, gooseberries, and jostaberries.

Cultivated Ribes are woody perennial shrubs ranging from 0.6 to $1.8 \mathrm{~m}$ in height. Red currant, white currant, gooseberry, and jostaberry fruits are borne primarily on spurs on 2- to 3-year-old wood. Black currants are borne on spurs on 1- to 2-year-old wood. In cultivation, canes older than 2 to 4 years are removed annually and replaced by new canes. The fruit are true berries. Currant berries are borne on string-like racemes containing a few to many berries. Gooseberries and jostaberries are borne singly or in small clusters. Table 1 shows typical fruit characteristics for domestic cultivars.

Ribes taxonomy has been confused for centuries. Currently, gooseberries and currants are located in Grossulariaceae (Cronquist, 1981; Sinnott, 1985). Debate continues over whether both should be assigned to the same genus. Anatomical studies (Stern et al., 1970), however, provided no justification for two genera, and a single genus (Ribes) is preferred today. Taxonomists have suggested dividing Ribes species into subgenera and sections or series (Brennan, 1990). 
European black currants are mostly descended from $R$. nigrum, although several cultivars trace blister rust resistance to $R$. ussuriense Jancz., which is native from Manchuria to Korea. Other important species in black currant breeding programs include $R$. dikuscha Fisch. from eastern Siberia and Manchuria, and $R$. bracteosum Dougl., the California black currant (Keep, 1976). Ribes nigrum sibiricum appears especially promising as a donor of disease resistance and fruit quality. In North America, the cultivar Crandall was developed from the clove or buffalo currant, $R$. odoratum Wendl. Red currants are largely derived from $R$. sativum Syme., $R$. rubrum, $R$. petraeum Wulf., and $R$. multiflorum Kit. White currants are simply a different color variation of red currants (Keep, 1975). European gooseberries are primarily derived from $R$. grossularia L. Ribes hirtellum Michx. and other North American species were crossed with $R$. grossularia in developing American cultivars.

Breeding currants and gooseberries is easy, and many cultivars have been named. Harmat et al. (1990) cite evidence of 4884 gooseberry cultivars alone worldwide. Genetically, all Ribes are diploid, with the basic chromosome number $x=8$. According to Keep (1975), "Within species, cross compatibility is the rule in Ribes, with very rare exceptions. Cross compatibility between species (in the sense that viable hybrids can be raised to maturity) is also usual between the morphologically similar members of the groups which comprise the series (and sometimes subgenera) of Berger (1924), the sections of Rehder (1954), and the subgenera of Keep (1962)." Jostaberries are hybrids between gooseberries and black currants. They are reportedly resistant to blister rust and powdery mildew.

\section{ADAPTABILITY AND GROWING CONDITIONS}

Domestic currants and gooseberries are adapted to cool, moist conditions. They are noted for their cold hardiness, which ranges between -25 and -31C or lower (Harmat et al., 1990; Holubowicz and Bojar, 1982). Cultivated Ribes require $\approx 800$ to $1600 \mathrm{~h}$ between 0 and 7C to meet chilling requirements (Westwood, 1978).

Domestic currants and gooseberries do not tolerate high temperatures well, especially when combined with intense sunlight. Research shows foliar damage may occur at 30C (Harmat et al., 1990). Consequently, north-facing slopes are usually recommended for currant and gooseberry fields. The crops can be grown in partial shade, but yields are better in full sun (Harmat et al., 1990). In southern climates, Ribes generally perform best at high elevations (Sears, 1925). Bloom requires 160 to 200 growing degree days (5C base), and production is generally possible in areas with 120 to 140 frost-free days (Harmat et al., 1990). The plants perform best on deep, organic-rich, well-drained soil with good water-holding capacity and a $\mathrm{pH}$ of 5.5 to 7.0. Heat damage and lack of chilling make Ribes cultivation difficult in southern climates. Figure 1 shows areas of North America where Ribes are traditionally grown commercially.

\section{RESEARCH EFFORTS}

Little breeding or other work with Ribes has been conducted in North America during the past 70 years. Present North American research is primarily directed at evaluating new cultivars developed in

Table 1. Ribes fruit characteristics. ${ }^{\mathrm{z}}$

\begin{tabular}{|c|c|c|c|c|c|}
\hline \multirow[b]{2}{*}{ Fruit } & \multicolumn{3}{|c|}{ Berry wt (g) } & \multirow{2}{*}{$\begin{array}{c}\text { Mean } \\
\mathrm{pH}\end{array}$} & \multirow{2}{*}{$\begin{array}{c}\text { Mean } \\
\text { TSS }^{y} \\
(\%)\end{array}$} \\
\hline & Mean & $\operatorname{Max}^{\mathrm{x}}$ & $\operatorname{Min}^{x}$ & & \\
\hline Black currants & 0.68 & 0.38 & 1.28 & 2.8 & 18.0 \\
\hline Red currants & 0.68 & 0.42 & 1.06 & 2.8 & 11.7 \\
\hline White currants & 0.60 & 0.52 & 0.66 & 2.9 & 12.5 \\
\hline Gooseberries $^{w}$ & 3.75 & 1.17 & 7.37 & 3.1 & 13.0 \\
\hline Jostaberry $^{\mathrm{v}}$ & 2.31 & --- & --- & 3.0 & 14.5 \\
\hline
\end{tabular}

${ }^{\mathrm{z}}$ Adapted from Barney and Gerton (1992).

${ }^{\mathrm{y}} \mathrm{TSS}=$ total soluble solids. This is a measure of sugar concentration in the berries.

${ }^{x}$ Values represent the ranges in average berry weights of the cultivars evaluated.

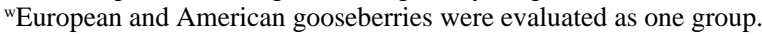

${ }^{v}$ Only one cultivar was available for evaluation.
Europe, where major breeding and research efforts are located. Serious production problems include white pine blister rust, American powdery mildew [Sphaerotheca mors-uvae (Schw.) Berk.], spring frost injury, and premature fruit drop. Blister rust and premature fruit drop are especially serious in black currants.

The prospects for improving currant and gooseberry cultivars for North American production are promising. In the northwestern United States, for example, Messinger et al. (1994) identified 34 Ribes species, saying that "High ecological diversity parallels this taxonomic diversity: a Ribes species occurs in nearly every terrestrial habitat, from sea level to above tree line and from swamp to desert." There is little likelihood, however, that commercial or university breeders in North America will take up the challenge of breeding Ribes soon. The International Ribes Association (based in California) has expressed interest in promoting a member-based breeding program.

\section{COMMERCIAL POTENTIAL IN U.S. MARKET}

Gooseberries, currants, and jostaberries are rich in vitamins A, B, and C. Some black currant cultivars contain about four times as much vitamin C as citrus fruits (Westwood, 1978). Ribes fruits also contain pectins, various mineral elements, and fructose. Black currant seeds are rich in essential fatty acids, such as gamma-linolenic acid (Brennan, 1990).

Currants are mostly used in the United States for making jellies, relishes, and juices. Red and white currants can be crushed and mixed with water to produce a lemonade-like drink called currant shrub. While their large, numerous seeds limit fresh consumption, the tart flavor of fresh, ripe red currants is very good. White currants also are good fresh, but are usually less flavorful than red currants and used primarily in Europe for baby food (Harmat et al., 1990).

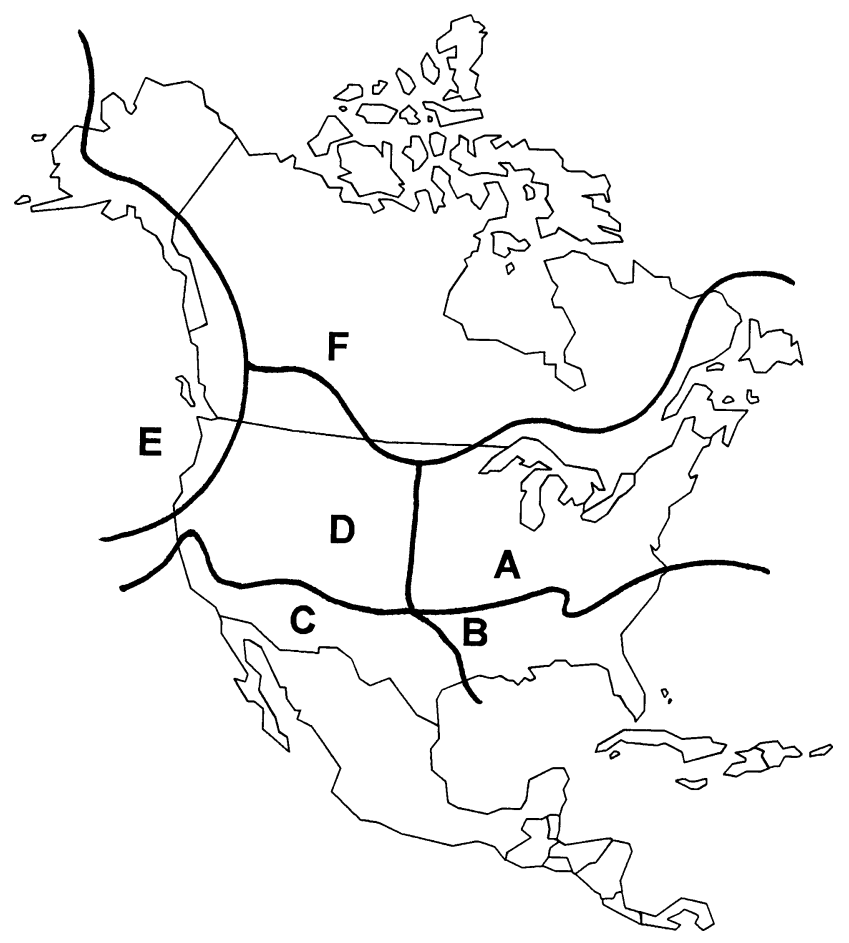

Fig. 1. Map of North America showing suitable climates for currants and gooseberries. Domestic currants and gooseberries are well adapted to regions $\mathrm{A}$ and $\mathrm{E}$. In region $\mathrm{B}$, the summers are typically too long and hot, and the plants may not accumulate sufficient winter chilling. Region $\mathrm{C}$ is too hot and dry for reliable production. Dry summers limit production in region $\mathrm{D}$, but currants and gooseberries can be grown with irrigation in some areas, particularly in northern latitudes or at high elevations. Region $\mathrm{F}$ is too cold for reliable production. Note that these regions are not sharply defined, but gradually blend into one another, depending on elevation and other factors. (Adapted from Darrow, 1922.) 
The leaves and buds of black currants are rich in phenolic compounds and have long been used for herbal medicines. In Russia, the leaves are used to make a tea resembling green tea in flavor. Because of their strong, "foxy" flavor, fresh black currants have never been widely popular in the United States. In Europe, black currants are used mostly in juices and occasionally for wines. The remainder of the fruit goes into jams and jellies, or is used to color yogurt and other dairy products (Brennan, 1990). Black currant juices are sold occasionally in North America, usually mixed with the juice of other fruits. Dale (1992) reported a demand for black currant products in Canada and estimated that "over 8,100 hectares of black currants would be needed to capture $1 \%$ of the North American juice market."

Gooseberries are used primarily in jams, jellies, compotes, and pastries. They resemble grapes in size, texture, and flavor, and can be eaten fresh. During the 1800s, 'Houghton' gooseberries were used as a substitute for cranberries (Card, 1907).

Jostaberry fruits are normally used for processing, but can be eaten out of hand. Like currants and gooseberries, jostaberries keep well when frozen.

Ribes crops are adaptable to a wide range of sites and are fairly easy to grow. Labor needed to grow currants, gooseberries, and jostaberries is about the same as for blueberries (Vaccinium spp.), and less than for many other berry crops. Hand picking costs are high, but currants and gooseberries can be mechanically harvested. Since Ribes fruits hang well on the bushes without over-ripening, the harvest window is much longer and provides more flexibility than strawberries (Fragaria $\times$ ananassa Duch.), raspberries, or blackberries (Rubus spp.). Currant, gooseberry, and jostaberry fruits are flavorful and suitable for a range of uses.

The greatest challenge Ribes growers in North America face is marketing. Although the fruits were popular here once, few people in North America under the age of 60 know what gooseberries or currants are, or have ever tasted them. Some people also equate currants and gooseberries with blister rust and dead pines. Virtually no one in North America has heard of jostaberries.

Another challenge Ribes growers face is stiff competition. During the golden age of currant and gooseberry production in North America, there was little commercial competition in the market. Raspberries and strawberries were common, but blueberries were just being domesticated. Deciduous tree fruits were available throughout Canada and the United States, but transportation technology limited the market for citrus and other tropical and semitropical fruits. Today, these commodities, along with exotic tropical fruits, are widely available throughout North America.

\section{CONCLUSIONS}

There is potential for commercial Ribes production in the United States and Canada. One potential market is nursery stock for hobby gardeners. Present supplies are limited in quantity, and the cultivars available largely consist of older, mildew- and/or rust-susceptible selections. There also is potential for limited commercial fruit production, particularly for local markets. High-value specialty products for niche markets also hold some promise. Marketing, including consumer education, however, is a serious challenge.

\section{Literature Cited}

Barney, D.L. and D. Gerton. 1992. An evaluation of the Ribes collection at the National Clonal Germplasm Repository, p. 13-19. In: P. Otten (ed.). 1992 Proc. Intl. Ribes Assn. Conf., Minneapolis, Minn., 11-12 Jan. 1992.

Berger, A. 1924. A taxonomic review of currants and gooseberries. New York State Agr. Expt. Sta. Bul. 109.

Brennan, R.M. 1990. Currants and gooseberries (Ribes), p. 457-488. In: J. Moore and J. Ballington (eds.). Genetic resources of temperate fruit and nut crops. Intl. Soc. Hort. Sci., Wageningen, The Netherlands.

Card, F.W. 1907. Bush fruits. Macmillan, New York.

Cronquist, A. 1981. An integrated system for classification of flowering plants. Columbia Univ. Press, New York.

Dale, A. 1992. Black currant potential in North America, p. 23-26. In: K. Hummer (ed.). Proceedings for the Ribes risk assessment workshop. U.S. Dept. Agr.-Agr. Res. Serv. Natl. Clonal Germplasm Repository, Corvallis, Ore.

Darrow, G.M. 1922. Currants and gooseberries. U.S. Dept. Agr. Farmers Bul. 1024 .

Harmat, L., A. Porpaczy, D.G. Himelrick, and G.J. Galletta. 1990. Currant and gooseberry management, p. 245-272. In: G. Galletta and D. Himelrick (eds.). Small fruit crop management. Prentice Hall, Englewood Cliffs, N.J.

Hedrick, U.P. 1925. The small fruits of New York. Rpt. New York State Agr. Expt. Sta. 30 June 1925.

Holubowicz, T. and K. Bojar. 1982. Cold tolerance studies of one year shoots of eight black currant cultivars. Fruit Sci. Rpts. 9:91-99.

Keep, E. 1962. Interspecific hybridization in Ribes. Genetica 33:1-23.

Keep, E. 1975. Currants and gooseberries, p. 197-268. In: J. Janick and J. Moore (eds.). Advances in fruit breeding. Purdue Univ. Press, West Lafayette, Ind.

Keep, E. 1976. Currants: Ribes spp. (Grossulariaceae), p. 145-151. In: N.W. Simmonds (ed.). Evolution of crop plants. Longman Group, New York.

Messinger, W., K. Hummer, and A. Liston. 1994. Wild Ribes of the Pacific Northwest. HortScience 29:507.

Rehder, A. 1954. Manual of cultivated trees and shrubs. 2nd ed. Macmillan, New York.

Sears, M.F. 1925. Productive small fruit culture. J.B. Lippencott Co., Philadelphia.

Shoemaker, J.S. 1948. Small-fruit culture. McGraw-Hill, Toronto.

Sinnott, Q.P. 1985. A revision of Ribes L. subg Grossularia (Mill.) pers. sect. Grossularia (Mill.) Nutt. (Grossulariaceae) in North America. Rhodora 87:189-286.

Stern, W.L., E.M. Sweitzer, and R.E. Phipps. 1970. Comparative anatomy and systematics of woody Saxifragaceae. Ribes. J. Linn. Soc. Bot. 63:215-237.

Westwood, M.N. 1978. Temperate-zone pomology. W.H. Freeman \& Co., San Francisco. 


\title{
The Pawpaw [Asimina triloba (L.) Dunal]: A New Fruit Crop for Kentucky and the United States
}

\author{
Desmond R. Layne ${ }^{1}$ \\ 129 Atwood Research Facility, Kentucky State University, Frankfort, KY 40601
}

\section{ORIGIN AND BOTANY}

The pawpaw is the largest tree fruit native to the United States (Darrow, 1975). This fruit, known commonly as the "poor man's banana," may reach up to $1 \mathrm{~kg}$ in weight. Pawpaws grow wild in the rich, mesic hardwood forests of 25 states in the eastern United States, ranging from northern Florida to southern Ontario (Canada) and as far west as eastern Nebraska (Kral, 1960). Pawpaws flourish in the deep, rich, fertile soils of river-bottom lands where they grow as understory trees or thicket-shrubs (Sargent, 1890). Pawpaw is the only temperate member of the Annonaceae family (Bailey, 1960), which includes several delicious tropical fruits, such as the custard apple (Annona reticulata L.), cherimoya (A. cherimoya Mill.), sweetsop or sugar apple (A. squamosa L.), atemoya (A. squamosa $\times$ A. cherimola), soursop (A. muricata L.), and biriba (Rollinia mucosa Baill.). In addition to the tropical annonas, there are eight other members of the Asimina genus that are native to the extreme southeastern states of Florida and Georgia. These include A. incarna (Bartr.) Exell (flag pawpaw), A. longifolia Kral, A. obovata (Willd.) Nash, A. parviflora (Michx.) Dunal (dwarf pawpaw), A. pygmaea (Bartr.) Dunal, A. reticulata Shuttlew. ex Chapman, A. tetramera Small (opossum pawpaw), and $A$. ×nashii Kral (Kral, 1960). The earliest documentation on pawpaws, which appeared in 1541, was from followers of the Spanish explorer Hernando De Soto, who found native peoples growing pawpaws in the Mississippi Valley (Pickering, 1879). They also used the bark for making fish nets.

\section{PLANT DESCRIPTION}

Pawpaw is a small, deciduous tree that may grow 5 to $10 \mathrm{~m}$ high, although the largest known tree is $230 \mathrm{~cm}$ in circumference (at $1.5 \mathrm{~m}$ height), $18 \mathrm{~m}$ tall, and $9 \mathrm{~m}$ in spread (American Forestry Association, 1990). In the forest understory, trees often exist in clumps or thickets, which may result from root suckering or seedlings developing from fruit that dropped to the ground from an original seedling tree (Gould, 1939). In sunny locations, trees typically assume a pyramidal habit, straight trunk, and lush, dark-green, long, drooping leaves (Fig. 1) that turn gold and brown during fall (Fig. 2). Leaves occur alternately, are obovate-oblong in shape, glabrous, with cuneate base, acute tip, and prominent midrib, and may be 15 to $30 \mathrm{~cm}$ long and 10 to $15 \mathrm{~cm}$ wide (Bailey, 1960). Vegetative and flower buds occur at different nodes on the stem, with flower buds being basipetal. Vegetative buds are narrow and pointed, whereas flower buds are round; both are covered with dark-brown, thick pubescence. Flowers emerge before leaves in

\footnotetext{
Received for publication 30 Sept. 1995. Accepted for publication 23 Oct. 1995. I thank R. Neal Peterson, R. Jones, and E.A. Sugden for some of the photographs used in the manuscript; and R.J. Barney, R.N. Peterson, and U.L. Yadava for suggestions regarding the manuscript. I thank R.L. Geneve, H. Huang, K. Kaul, R.N. Peterson, and D.E. Riemenschneider for scientific input toward the research projects described herein. The technical assistance of M.G. Kwantes, S.C. Jones, E.B. Reed, Jr., C.L.H. Finneseth (Univ. of Kentucky graduate student), and S. Johnson, S. Larkin-McMillon, O. Mitchell, and D. Prince (all Kentucky State Univ. undergraduate students), and L. Jones (a high school research apprentice) is gratefully acknowledged. Use of trade names and individual sources does not imply endorsement of the products named nor criticism of similar ones not named by Kentucky State Univ. In some cases, more than one commercial source is available for the products mentioned. The preparation of this paper was supported by U.S. Dept. of Agriculture/Cooperative State Research Service Agreement no. KYX-10-92-19P.

${ }^{1}$ Principal Investigator of Horticulture and Curator, U.S. Dept. of Agriculture National Clonal Germplasm Repository for Asimina spp., Kentucky State Univ., and Adjunct Assistant Professor of Horticulture, Dept. of Horticulture and Landscape Architecture, Univ. of Kentucky, Lexington, KY 40546.
}

midspring (Fig. 1). In the mid-Atlantic states and Ohio Valley, pawpaws usually flower immediately after the peak of dogwood (Cornus florida L.) flowering. Blossoms occur singly on previousyear's wood and may reach up to $5 \mathrm{~cm}$ in diameter. Individual flowers are pendant on nodding, sturdy, pubescent peduncles up to $4 \mathrm{~cm}$ long (Kral, 1960). Mature flowers have an outer and inner layer of three, maroon-colored, three-lobed petals (Fig. 1). Inner petals are smaller and more fleshy, with a nectary band at the base. Flowers have a globular androecium and a gynoecium composed of three to seven carpels (Kral, 1960). The actual upper limit for carpel count may be nine or higher, based on the finding of nine-fruited clusters (R.N. Peterson, The PawPaw Foundation, personal observation). Flowers are strongly protogynous and self-incompatible, and require crosspollination (Wilson and Schemske, 1980), although some trees may be self-compatible. Pollination may be by flies (Wilson and Schemske, 1980) and beetles (Kral, 1960), which is consistent with the presentation appearance of the flower: dark, meat-colored petals and a fetid aroma. Fruit set in the wild is usually low and may be pollinator- or resource-limited (Wilson and Schemske, 1980), but under cultivation, tremendous fruit loads have been observed (R.N. Peterson, personal communication). Fruit are oblong-cylindric berries that are typically 3 to $15 \mathrm{~cm}$ long, 3 to $10 \mathrm{~cm}$ wide, and weigh 200 to $400 \mathrm{~g}$. They may be borne singly or in clusters that resemble the "hands" of a banana plant (Musa spp.) (Figs. 1 and 2). This highly aromatic, climacteric fruit has a ripe flavor that resembles a creamy mixture of banana (Musa $\times$ paradisiaca L.), mango (Mangifera indica L.), and pineapple [Ananas comosus (L.) Merr.] (McGrath and Karahadian, 1994). When ripe, skin ranges from green to brownish-black, and the flesh ranges from creamy white through bright yellow to shades of orange (Fig. 2). The skin should not be eaten. Shelf life of a tree-ripened fruit stored at room temperature is 2 to 3 days. With refrigeration, fruit can be held up to 3 weeks while maintaining good eating quality. Within the fruit, there are two rows of large, brown, bean-shaped, laterally compressed seeds that may be up to $3 \mathrm{~cm}$ long (Fig. 2). In the wild, the primary fruit consumers and seed dispersers are raccoons [Procyon lotor (L.) Elliot], red foxes [Vulpes fulvus (Desmarest) Merriam], and opossums (Didelphis virginiana Kerr) (among others) who eat fruit that have fallen to the ground (Peterson, 1991). Seeds contain alkaloids in the endosperm that are emetic (Vines, 1960). If chewed, seed poisons may impair mammalian digestion, but if swallowed whole, seeds may pass through the digestive tract intact.

\section{PROPAGATION AND CULTIVATION}

\section{Seedling production}

As soon as flesh is soft, collect fruit for seed. Avoid excessive fermentation of the fruit, as prolonged exposure to the fermentation products may injure and kill the seed. Seeds are easily extracted following maceration of the fruit in water and floating off of pulp [U.S. Dept. of Agriculture (USDA), 1948]. Sterilize seed by shaking them with a $10 \%$ to $20 \%$ sodium hypochlorite solution for 1 to $2 \mathrm{~min}$ followed by several rinses of distilled water. This step aids in reducing fungal and bacterial contamination during storage. Do not allow seeds to dry out. Once cleaned, store them refrigerated in self-closing polyethylene bags with slightly moist sphagnum (or peat) moss. Label the bags, using indelible ink, as to the seed source, extraction date, and other pertinent information for future reference. Seeds have a dormant, immature embryo and require stratification (USDA, 1948). Storage under refrigeration (5C) for 100 days is recommended to overcome embryo dormancy (USDA, 1948). Provided that desiccation and microbial contamination do not occur, seeds may be stored for several 

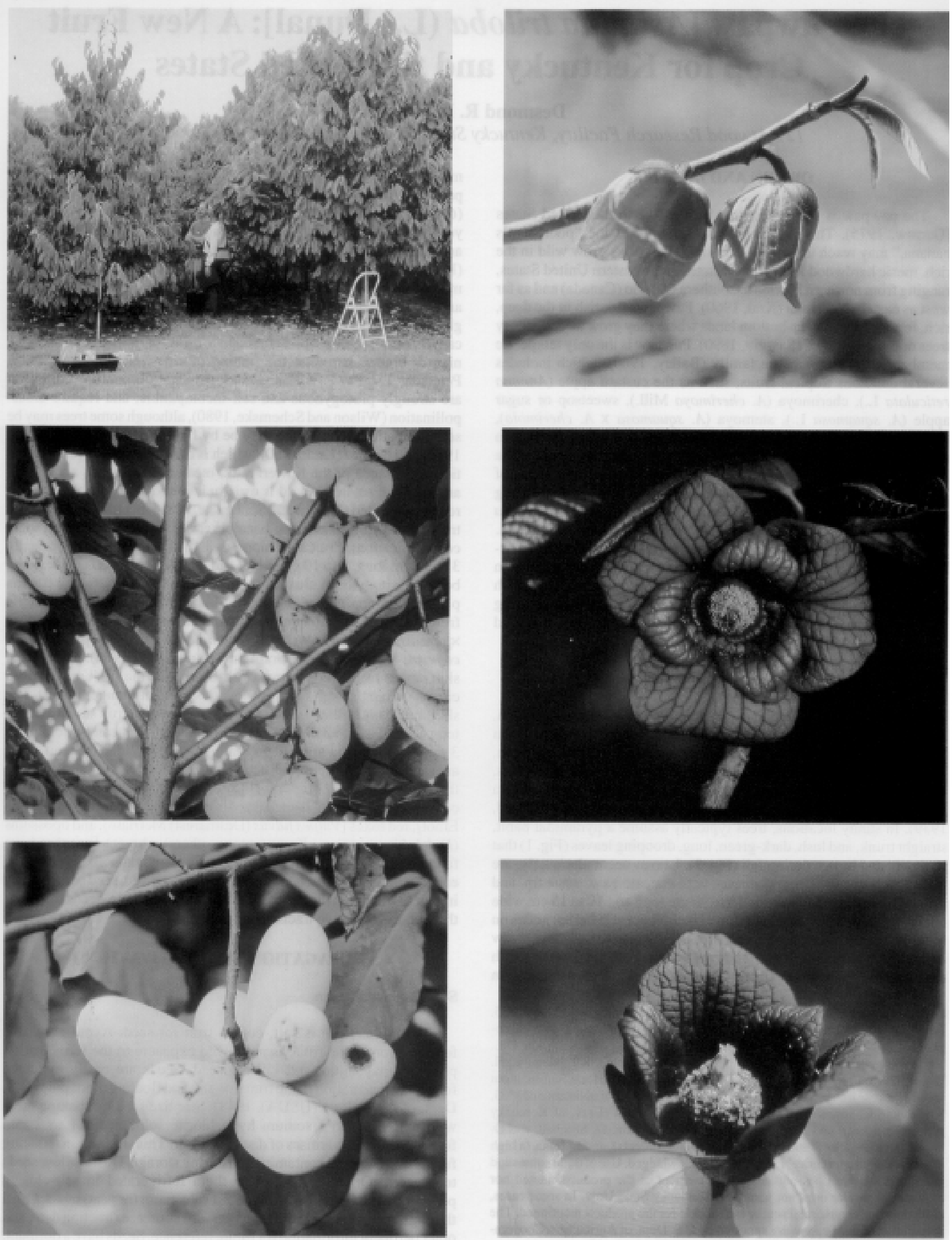

Fig. 1. (clockwise from top left) Ten-year-old pawpaw seedling trees in commercial-type orchard planting at harvest (9 Sept. 1993, Keedysville, Md.); flower blossom before dehiscence (20 Apr. 1994, Frankfort, Ky.); flower at dehiscence (mid-May 1994, Frankfort, Ky.; photo by E.A. Sugden); ovary swelling, early fruit cluster development (late May 1994, Frankfort, Ky.; photo by E.A. Sugden); cluster of eight fruit (9 Sept. 1993, Keedysville, Md); fruit on tree (photo by R. Jones). 

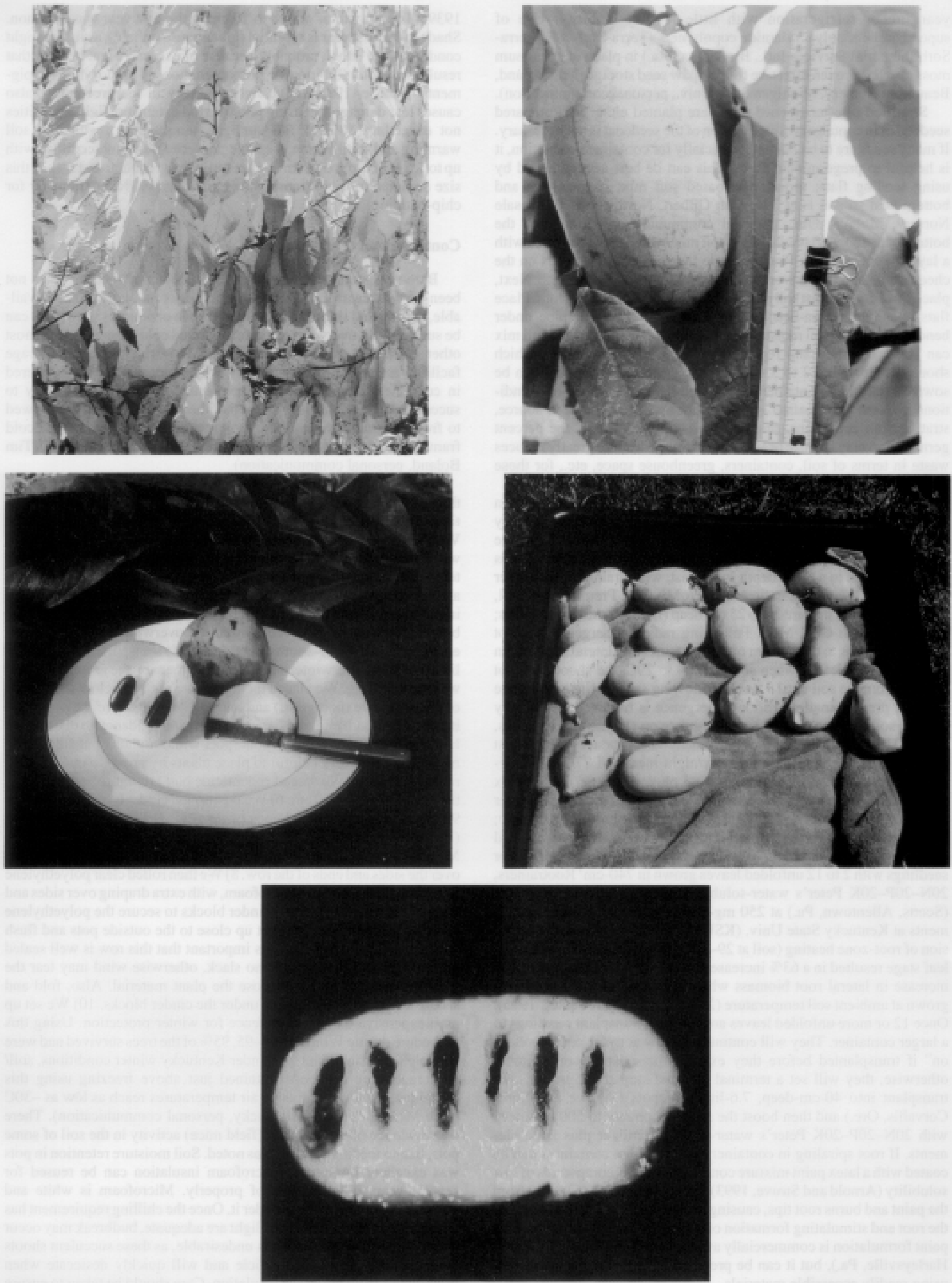

Fig. 2. (clockwise from top left) Fall color (October, Keedysville, Md.; photo by R.N. Peterson); single 900-g fruit (9 Sept. 1993, Keedysville, Md.); fruit immediately following harvest (9 Sept. 1993, Keedysville, Md.); longitudinal section of ripe fruit; cross section of ripe fruit (photo by R.N. Peterson). 
years under refrigeration with little loss in viability. Use of superabsorbent polyacrylamide copolymers (Terra-Sorb AG; TerraSorb Industrial Services Intl., Bradenton, Fla.) in place of sphagnum moss also has proven effective for pawpaw seed storage (Tim Boland, Beaumont Nursery, Michigan State Univ., personal communication).

Stratified or after-ripened seeds are planted either in a prepared seedbed or in containers. Scarification of the seedcoat is not necessary. If many seeds are to be planted, especially for container production, it is helpful to pregerminate them. This can be best accomplished by using seeding flats; moist, peat-based soil mix; cheesecloth; and bottom heat so soil is at 32C (Jim Gilbert, Northwoods Wholesale Nursery, Molalla, Ore., personal communication). First, line the bottom of a seeding flat with moist soil mix, which then is covered with a layer of cheesecloth. Place a single layer of stratified seeds on the cheesecloth, and then cover it with another layer of cheesecloth. Next, place 1 to $3 \mathrm{~cm}$ of moist soil mix over the top layer of cheesecloth. Place flats over the bottom-heat source (heat mat, hot-water pipe under bench, etc.). Keep soil moist. The top layer of cheesecloth and soil mix can be easily lifted and replaced to check for germination, which should occur within 2 to 3 weeks. Pregerminated seeds can then be sown directly into containers (described below). Under ideal conditions, percent germination is $\approx 90 \%$, but depending on seed source, stratification conditions, microbial contamination, etc., the percent germination may be $60 \%$ or less. Use of this procedure greatly reduces waste in terms of soil, containers, greenhouse space, etc., for those seeds that do not germinate.

Pawpaw seed germination is hypogeal and cotyledons remain within the seedcoat. Finneseth et al. (1996) postulated that the primary function of the cotyledons is absorption of food reserves from the ruminate endosperm for transfer to the developing seedling. Seeds should be sown to a $3-\mathrm{cm}$ depth in a moist, well-drained soil or other medium that has good aeration (i.e., ProMix BX; Premier, Red Hill, $\mathrm{Pa}$.) in containers that are 20 to $25 \mathrm{~cm}$ deep (i.e., $740-\mathrm{cm}^{3}$ Rootrainers; Hummert, Earth City, Mo.). Following radicle emergence, taproot growth proceeds to the bottom of the container and lateral roots begin to develop. Typically, when soil is at 24 to $29 \mathrm{C}$, the shoot does not emerge from the soil until 9 weeks following sowing (including time spent in pregermination). Shoot emergence is hastened 10 days by heating soil to 29 to $32 \mathrm{C}$ from sowing date on (Layne and Kwantes, 1995). The optimal conditions for greenhouse production of robust seedlings include the following: day/night means of 27/24C; maximum light intensity $1000 \mu \mathrm{mol} \cdot \mathrm{m}^{-2} \cdot \mathrm{s}^{-1}$ photosynthetic photon flux (greenhouse whitewashing recommended, especially during summer months); 16-h photoperiod (extended by high-pressure sodium lamps); fertilization $2 \times$ per week to runoff during shoot growth phase; and soil at 29 to 32C (Jones et al., 1995; Layne and Kwantes, 1995). For seedlings with 2 to 12 unfolded leaves grown in $740-\mathrm{cm}^{3}$ Rootrainers, 20N-20P-20K Peter's water-soluble fertilizer plus trace elements (Scotts, Allentown, Pa.) at $250 \mathrm{mg} \cdot \mathrm{liter}^{-1}$ is optimal. Recent experiments at Kentucky State Univ. (KSU) have demonstrated that provision of root-zone heating (soil at 29-32C) from sowing date to the 12leaf stage resulted in a $63 \%$ increase in total plant biomass and a $90 \%$ increase in lateral root biomass when compared to those seedlings grown at ambient soil temperature (24C) (Layne and Kwantes, 1995). Once 12 or more unfolded leaves are attained, transplant seedlings to a larger container. They will continue to grow actively once "pottedon" if transplanted before they exhaust the existing soil volume; otherwise, they will set a terminal bud and stop shoot growth. We transplant into 40-cm-deep, 7.6-liter Treepots (Stuewe and Sons, Corvallis, Ore.) and then boost the fertilization rate to $500 \mathrm{mg} \cdot$ liter $^{-1}$ with 20N-20P-20K Peter's water-soluble fertilizer plus trace elements. If root spiraling in containers is a problem, containers can be coated with a latex paint mixture containing copper compounds of low solubility (Arnold and Struve, 1993). The copper leaches locally from the paint and burns root tips, causing lateral branching farther back on the root and stimulating formation of a more fibrous root system. This paint formulation is commercially available as SpinOut (E.C. Geiger, Harleysville, Pa.), but it can be prepared by the user for lower cost using readily accessible materials.

In the past, recommendations for pawpaw seedling production included growing seedlings outside, in a seedbed under shade (Gould,
1939). Top growth of only 8 to $10 \mathrm{~cm}$ in the first year was common. Shade in the first year is essential (greenhouse or field), as full sunlight conditions are lethal, probably because of excessive leaf heating that results in photoinhibition or photooxidation of photosynthetic pigments (Krause, 1988). High light intensity in the greenhouse also causes leaf damage. By using photoperiod extension, light intensities not exceeding $50 \%$ of full sunlight, temperature regulation, soil warming and fertilization, we have produced pawpaw seedlings with up to $1.5 \mathrm{~m}$ of top growth in one season in the greenhouse. Trees of this size are ideal for field transplanting and have sufficient diameter for chip-budding.

\section{Containerized overwintering}

Bare-root storage and/or shipping of pawpaw seedlings has not been very successful. Until reliable bare-root methods become available, storing and shipping trees should be in containers. Pawpaws can be successfully overwintered in refrigerated cold storage, as can most other container-grown nursery crops. If refrigerated cold-storage facilities are unavailable, pawpaws can be successfully overwintered in containers outside if adequate precautions are taken. A key to successful overwinter survival is that the root system not be allowed to freeze. Containers can be overwintered in insulated, heated cold frames provided root-zone temperature does not drop below -7C (Tim Boland, personal communication).

At KSU (USDA hardiness zone 6), we have overwintered more than 2000 trees successfully on the ground outside without an additional heat source. This was accomplished in the following manner: 1) We acclimated seedlings in the greenhouse to a dormant condition by withholding fertilization, reducing watering, lowering greenhouse temperature, and removing supplemental illumination. 2) We defoliated dormant seedlings in the greenhouse and thoroughly watered immediately before taking them outdoors in the fall. Do not prune trees before overwintering. 3) We mowed the overwintering site and oriented rows in a north-south direction. 4) We transported trees in 7.6liter pots to the overwintering site and laid them on the ground, six pots wide and 75 long. We placed the top of one pot just below the bottom of the pot above (north of it) and laid the stem on top of the pot above it. Since the south end of the row has a greater tendency to dry out, we laid down a row of "blank" pots (pots without plants but filled with moist soil). It is very helpful to place plants by group to make spring removal easy. 5) We spread rodenticide bait around the perimeter of the row every 60 to $90 \mathrm{~cm}$. 6) We positioned cinder blocks every 60 to $90 \mathrm{~cm}$ along the sides and ends of the row. 7) We rolled microfoam (laminated polypropylene) horticultural insulation blanket (Ametek Microfoam Div., Chaddsford, $\mathrm{Pa}$.) over the pots and left extra to drape over the sides and ends of the row. 8) We then rolled clear polyethylene ( $0.01 \mathrm{~mm}$ thick) over the microfoam, with extra draping over sides and ends of the row. 9) We used cinder blocks to secure the polyethylene as the microfoam was brought up close to the outside pots and flush with the soil for a tight fit. It is important that this row is well sealed on all sides and that there is no slack, otherwise wind may tear the polyethylene and unduly expose the plant material. Also, fold and secure any extra polyethylene under the cinder blocks. 10) We set up an inexpensive electric deer fence for winter protection. Using this procedure during Winter 1994-95, 95\% of the trees survived and were suitable for spring planting. Under Kentucky winter conditions, soil/ air temperature can be maintained just above freezing using this technique, even when outside air temperatures reach as low as $-30 \mathrm{C}$ (Bob McNeil, Univ. of Kentucky, personal communication). There was evidence of some rodent (field mice) activity in the soil of some pots, but no feeding damage was noted. Soil moisture retention in pots was excellent by spring. Microfoam insulation can be reused for several years if taken care of properly. Microfoam is white and transmits light to the plants under it. Once the chilling requirement has been met and temperature and light are adequate, budbreak may occur under the microfoam, which is undesirable, as these succulent shoots have a poorly developed cuticle and will quickly desiccate when brought out from under the insulation. Care should be taken to ensure that plants are brought out not only before budbreak but also after the last threat of a killing frost. 


\section{Field planting}

Plant trees in the field when they are still dormant. Although trees can be planted in the fall, this is a more risky practice than spring planting. To ensure success in fall planting, the trees must be hardenedoff and acclimated properly (i.e., naturally defoliated). Plant them before the first killing frost. Spring-plant a dormant tree that has had its chilling requirement fulfilled at the time of local, native pawpaw budbreak (early April in Kentucky). Planting holes should match the existing containerized root system. For 7.6-liter containers, a handheld power auger with an 8-inch drill bit works nicely for drilling holes. Do not plant trees when soil is too dry or wet. Hole drilling in wet, clayish soils will result in glazing the hole walls, which may impede root penetration into the soil. Soil should be well drained, deep, fertile, and slightly acid (i.e., $\mathrm{pH}$ 5.5-7). Preplant soil tests are desirable to make necessary amendments. Plant trees such that the soil line of the pot is even with the soil line of the field. Water-in trees immediately after planting to ensure adequate root-to-soil contact. Seedlings must also receive adequate water in the year of establishment. Pawpaw trees establish and grow best when they are given shelter the first year in the field. This is accomplished by using tree shelters that are used in reforestation (i.e., 1-m TUBEX tree shelters; Treessentials Co., St. Paul). Tubes can be secured to steel reinforcing bars or pressure-treated wooden posts. Tree shelters provide several benefits in the year of establishment: 1) reduction of light intensity incident upon tree; 2) wind reduction; 3) water conservation; 4) protection from browsing animals; and 5) protection from herbicides. At least one nursery that sells container-grown pawpaw trees also sells tree shelters and strongly urges their customers to use them. This practice has significantly reduced the need to send replacement plants later (Ken Asmus, Oikos Tree Crops, Kalamazoo, Mich., personal communication). Tree tubes are not without problems, however. Mice sometimes are attracted to them as winter shelters; invariably they sever the sapling's trunk to enlarge their nests (R.N. Peterson, personal communication). Occasionally, fall acclimation of trees grown in shelters may be delayed and tip dieback from cold injury may occur. Tree shelters may not be well suited in the Deep South of the United States. They have caused excessively high temperatures that are injurious to the plant (Dean Evert, Univ. of Georgia, personal communication). If seedlings or grafted trees to be planted are $1 \mathrm{~m}$ or taller, tree shelters are not needed.

Weed control is necessary, especially in the establishment year. Depending on site, soil erodibility, whether tree shelters are used, etc., herbicides can be used to control weeds. At KSU we have used wood chip mulch to a $15-\mathrm{cm}$ depth and have achieved good weed control and water conservation in the year of mulching. This step is labor intensive, and cost is a factor if one does not have access to free or low-cost chips. In the Deep South, mulch breaks down too readily to be practical (Dean Evert, personal communication). Another alternative is weed mats (VisPore tree mats; Treessentials Co., St. Paul). Mats are $1 \mathrm{~m}^{2}, 0.06$ $\mathrm{mm}$ thick, ultraviolet-stabilized black polyethylene, with 620 heatmolded microfunnels per $10 \mathrm{~cm}^{2}$. Weed competition is restricted from the root zone and water conservation is greatly enhanced for up to 3 years. These tree mats are designed to be used along with tree shelters to conserve water and avoid supplemental irrigation.

Granular fertilizer can be broadcast in the spring. Fertigation with liquid fertilizer can be useful if drip irrigation is installed in the orchard. If weed mats are used, run the drip line and emitters under the mats. We do not currently have recommendations for feeding fieldplanted trees, but we fertigate with $20 \mathrm{~N}-20 \mathrm{P}-20 \mathrm{~K}$ Peter's watersoluble fertilizer plus trace elements at $500 \mathrm{mg} \cdot \mathrm{liter}^{-1}$ once in May, June, and July during the active growth phase. Fertilizer recommendations based on foliar and soil analyses need to be developed. Recommended tree spacing at present is $5.5 \mathrm{~m}$ between rows and $2 \mathrm{~m}$ apart in the row. Row orientation should be north-south.

Transplanting trees from the wild usually is unsuccessful. Young trees dug from a thicket or grove are often root suckers with few, brittle roots that have very few root hairs. Due to the poorly developed root system and frequent absence of shelter following transplanting, transplanting shock is usually severe, resulting in the death of the root sucker. Transplanting seedlings is most successful when done in the spring during budbreak. If many roots are lost during digging, prune the shoot to bring it into balance with the existing root system. Containerized seedlings transplant with high success.

\section{Vegetative propagation}

Pawpaws are easily propagated by several cloning methods, such as grafting and budding. These techniques include whip-and-tongue, cleft, bark inlay, and chip budding. Chip budding is most successful when the seedling rootstock is at least pencil thick in diameter and actively growing. Winter-collected, dormant scion budwood should have had its chilling requirement fulfilled. Do not graft flower buds onto rootstock. For storage, dip the shoot bases of the budwood in paraffin, place in a labeled polyethylene bag, and heat-seal it. Under these conditions, budwood can be stored reliably in a refrigerator for up to 3 months. Do not allow budwood to dry out, but I do not recommend wetting paper towels or adding free water to the plastic bags, as this can lead to microbial overgrowth. Larger vegetative buds have a higher success rate than smaller buds. When performing chip budding, try to match the diameter of the budwood with that of the stock plant. It is best to place buds on the smooth side of the stock between the nodes. Since vegetative buds occur oppositely and alternately on the stock and branching occurs in one plane, budding on the side perpendicular to this plane reduces confusion as to which shoot is the grafted one. I recommend wrapping the graft with Parafilm M laboratory film (American National Can, Greenwich, Conn.) strips cut to $2 \times 15 \mathrm{~cm}$. Parafilm $\mathrm{M}$ is flexible, moldable, self-sealing, and moisture resistant. When stretched, it applies adequate pressure to stimulate callus production and it maintains good humidity for union formation. We wrap buds starting one wrap above the bud, proceeding over the bud to one wrap below, and then returning back up and tying off above the bud. Within 2 weeks, buds will begin expanding and may penetrate the Parafilm M or just enlarge under it. In the latter case, Parafilm $\mathrm{M}$ is easily removed by using a sharp budding knife and making a shallow incision along the length of the wrap on the side opposite the bud. Take care not to damage the scion bud in the process of removing Parafilm M. Once scion growth commences, we recommend cutting back the top of the stock to 30 to $60 \mathrm{~cm}$ in height, leaving six or more functional lower leaves, and rubbing off all competing buds on the rootstock. This procedure will reduce apical dominance and enable the bud to grow actively while maintaining photosynthesis to supply carbohydrates and nutrients for the developing scion. We have found that cutting the stock back to just above the bud reduces scion growth. Once the scion is $30 \mathrm{~cm}$ long or more, remove the lower leaves on the stock and cut the stock back to a height of 20 to $25 \mathrm{~cm}$ above the union. Under greenhouse conditions, we also have found that leaving the stock as described above is extremely helpful because the stub of the stock projecting above the union then provides a "stake" to secure the growing scion. Some scion varieties appear to grow more horizontally from the graft union than others and using this technique ensures uniform habit and development of a strong union and vertically oriented scion. We use masking tape to tie up the scion as it grows. Once the scion becomes woody, this tape is no longer needed. Starting with a large, healthy rootstock, up to $1.5 \mathrm{~m}$ of scion growth can be attained in as few as 3 months under the optimal greenhouse conditions described above. Whip grafting is successful on seedling rootstock material that is as small as 3 to $4 \mathrm{~mm}$ in diameter, provided the scion is of similar diameter (Jim Gilbert, Northwoods Wholesale Nursery, Molalla, Ore., personal communication).

Other vegetative (clonal) propagation techniques such as root cuttings, hard and softwood cuttings, and tissue culture have met with poor or marginal success in the past by others. Current efforts here at KSU have demonstrated that winter-harvested root cuttings will sucker profusely when grown in the greenhouse with bottom heat. We have had more success with large ( $>2 \mathrm{~cm}$ in diameter) cutting pieces than smaller cuttings. We are attempting to root these cuttings and to culture nodal explants. One commercial business is attempting to root pawpaw hardwood cuttings in the greenhouse (Mike Byrne, Propagation Technologies, Lawton, Mich., personal communication). We are also conducting experiments to clonally propagate pawpaws by softwood cuttings and mound layering in the field. Hickman (1985) 
successfully rooted a low percentage of pawpaw softwood cuttings. Micropropagation techniques have been developed for many Annonaceous relatives of pawpaw, indicating promise of this technology for pawpaw (Bejoy and Hariharan, 1992; Jordan, 1988; Jordan et al., 1991; Nair et al., 1983, 1984a, 1984b, 1986; Rasai et al., 1994). In attempting to micropropagate pawpaw, we have found that dormant, winter-harvested twigs that are surface-sterilized and then forced (in water) in a growth chamber provide the best source of explants (i.e., nodal cuttings) from the newly developing shoots. We currently have adventitious shoots proliferating in culture and will soon move them to a rooting medium. Embryo culture is a technique that might be used to rescue interspecific or intergeneric hybrids that would otherwise abort due to incompatibility (Pierik, 1989).

\section{Weed and pest control}

No chemicals are currently registered for commercial use on pawpaws. We use $N$-(phosphonomethyl)glycine (glyphosate; RoundUp) and 1,1'-dimethyl-4,4'-bipyridinium salts (paraquat) for maintaining a weed-free, herbicide strip down orchard rows in our research plots. We have had only minor infestations in the field of Japanese beetle (Popillia japonica Newman), and 1-naphthalenyl methylcarbamate (carbaryl; Sevin) is effective in treating this pest. Greenhouse pests include aphids (Family: Aphididae) and thrips (Family: Thripidae). Sevin is also effective for these pests in the greenhouse.

\section{RATIONALE FOR DEVELOPMENT OF PAWPAW AS A NEW FRUIT CROP}

The economic rationale for the development of pawpaw as a new fruit crop is very much tied to the need, in certain areas of the country, to find new high-value crops to replace old ones that are losing value. Tobacco (Nicotiana tabacum L.) is one example. Since 1976, the percentage of total world tobacco produced by the United States has dropped from $53 \%$ to $28 \%$ (Owens, 1994b). Significant opportunities exist for the development of alternative agricultural enterprises that could help tobacco farmers to diversify and thereby enhance their continued, long-term viability.

In Kentucky, tobacco is grown on small acreages in rural areas and tobacco sales contribute significantly to the small-farm family income. At KSU the central mission of the land-grant program is to address the needs of limited-resource (small) farmers, most of whom will be harmed by declines in tobacco production and revenue generation (Gale, 1994). One current, long-term and ongoing initiative at $\mathrm{KSU}$ to address the aforementioned need is the development of pawpaw as a new, commercial, tree fruit crop. Pawpaw is well adapted to all 16 tobacco-growing states in the United States, except Florida. Pawpaw cultivation in these tobacco-producing states can add diversity and has the potential to provide significant income for a portion of these states' farmers over 20 to 30 years.

\section{COMMERCIAL POTENTIAL}

Pawpaw has tremendous potential as a new fruit crop because of its 1) adaptation to existing climatic and edaphic conditions; 2) nutritional and cosmetic value of the fruit; 3) valuable natural compounds; 4) nursery wholesale and retail tree production; and 5) use as a component in residential "edible" landscapes. Pawpaw is well adapted to the 25 states to which it is native and where it already grows in the wild. It is hardy to zone $5(-25 \mathrm{C})$ and requires a minimum of $400 \mathrm{~h}$ annual chill units, 160 frost-free days, and $80 \mathrm{~cm}$ of annual precipitation, with most falling during spring and summer (Peterson, 1991). Pawpaw trees may be used for habitat restoration and biodiversification in parks, wood lots, and forests. Pawpaw is an excellent food source. It exceeds apple (Malus domestica Borkh.), peach [Prunus persica (L.) Batsch.], and grape (Vitis spp.) in most vitamins, minerals, amino acids, and food energy value (Peterson et al., 1982). Pawpaw fruit are best eaten fresh when fully ripe. The intense tropical flavor and aroma (Shiota, 1991) also may be useful for developing processed food products (blended fruit drinks, baby food, ice creams, etc.). The flesh purees easily and freezes nicely. Pawpaws easily substitute in equal part for banana in most recipes (Jones and Layne, 1996). Aromas may be used commercially in cosmetics and skin products (B. Hecking, perfume chemist, Mane, USA Division, Wayne, N.Y., personal communication). Pawpaw plants produce natural compounds (annonaceous acetogenins) in leaf, bark, and twig tissues that possess both highly antitumor and pesticidal properties (McLaughlin and Hui, 1993; Mikolajczak et al., 1988; Rupprecht et al., 1986; Zhao et al., 1994). Current research by Jerry McLaughlin at Purdue Univ. (personal communication) suggests that a potentially lucrative industry, based simply on production of plant biomass, could develop for production of anticancer drugs [pending Food and Drug Administration approval] and natural (botanical) pesticides. The high level of natural defense compounds in the tree make it highly resistant to insect/disease infestation (R.N. Peterson, personal observation). With proper management, organic commercial fruit production may be possible. Currently in the United States, there are more than 40 commercial nurseries selling pawpaw trees. Seedling and grafted trees in the retail nursery trade are currently selling briskly for as much as $\$ 18.50$ and $\$ 26.50$ a piece, respectively, vs. $\$ 3.00$ to $\$ 4.00$ for a 2 -year-old, grafted apple tree. Currently, standing orders are in excess of 40,000 trees in the wholesale market (Jim Gilbert, personal communication). Pawpaws are ideally suited for the residential "edible" landscape due to their lush, tropical appearance; attractive growth form; size; fall color; and delicious fruit. In addition, Asimina spp. are suitable for butterfly gardens, as they attract the zebra swallowtail (Eurytides marcellus Cramer), for whom they are the exclusive larval host plant (Damman, 1986).

\section{PUBLIC INTEREST AND HISTORY}

Pawpaws have a well-established place in folklore and American history. "Where, oh where, is dear little Nellie (Sallie, etc.)? 'Way down, yonder in the pawpaw patch." This traditional American folk song and game was quite popular once and hunting for pawpaws in the woods in the fall is a cherished tradition for many rural families in the southeastern United States. In reference to the pawpaw, John Lawson said in his 1709 book, A New Voyage to Carolina, that they are "as sweet, as any thing can well be. They make rare Puddings of this Fruit." John Filson, an early settler, promoter, and developer of Kentucky, said in his 1784 book, The Discovery, Settlement and Present State of Kentucke, "the pappa-tree does not grow to a great size, is a soft wood, bears a fine fruit much like a cucumber in shape and size, and tastes sweet." Daniel Boone and Mark Twain were reported to have been pawpaw fans. In their journal entry on 18 Sept. 1806, Lewis and Clark recorded how pawpaws helped save them from starvation, "our party entirely out of provisions subsisting on poppaws. We divided the buiskit which amounted to nearly one buiskit per man, this in addition to the poppaws is to last us down to the Settlement's which is 150 miles. The party appear perfectly contented and tell us that they can live very well on poppaws". John James Audubon painted the yellow-billed cuckoo on a native pawpaw tree (ca. 1827). During the famous Hatfield-McCoy feud along the Kentucky-West Virginia border, on 9 Aug. 1882, three sons of Randolph McCoy (clan leader) were tied to pawpaw bushes and executed by the rival Hatfield family (Owens, 1994a). Several American towns, townships, creeks, and rivers were named after the pawpaw during the 19th century.

Several national organizations have had a long-standing interest in pawpaws, including the Northern Nut Growers Association, the North American Fruit Explorers, and the California Rare Fruit Growers, Inc. In 1988, R. Neal Peterson founded The PawPaw Foundation (PPF) as a nonprofit organization "dedicated to research and development of Asimina triloba as a new fruit crop for American farmers and consumers." Currently, PPF has almost 300 members. PPF, under the leadership of Peterson, has been active in collecting, evaluating, and preserving germplasm; breeding pawpaws; distributing fruit; selling seed; interacting with research scientists; and educating the public. PPF receives hundreds of letters each year requesting information about pawpaws. PPF also publishes a semi-annual newsletter, "From The 
PawPaw Patch." Here at KSU, I have received more than 700 inquiries (phone calls, letters, e-mail) in the last 6 months alone from people across the United States seeking information about pawpaws and the availability of fruit, trees, and seeds. Many of these people have shared wonderful reminiscences of this fruit. Others express great enthusiasm and excitement upon learning that someone is finally taking an academic interest in pawpaws. One recent caller wanted to know where he could get a semi-truck load of fruit to market in downtown Los Angeles! The affection pawpaw "enthusiasts" have for this historically neglected and uniquely American native fruit is quite remarkable. Public interest has been fueled by high-profile articles in several newspapers, including The Wall Street Journal, USA Today, Baltimore Sun, Detroit Free Press, Lafayette Journal and Courier, Lexington Herald Leader, Frankfort State Journal, and Windsor Star. Recent features also have been published in popular magazines, including American Horticulturist (Feb. 1995), Country America (Sept. 1995), and The Fruit Gardener (May/June and July/August 1996). I was interviewed on 5 Dec. 1995 about pawpaws by Noah Adams on National Public Radio's daily program “All Things Considered."

Whether curiosity, folklore, the exotic nature of the fruit and tree, or genuine commercial interest, pawpaws are beginning to gain considerable attention across the United States. This national attention is a mixed blessing. It is great exposure for promoting pawpaw's commercial development, but we are at the infancy stage in terms of academic research and industry development (fruit production, processing, marketing, etc.) and we have only limited information for those who seek more. Scientifically based recommendations, which are a prerequisite for industry development, take many years of research to develop.

\section{PAWPAW RESEARCH AT KENTUCKY STATE UNIV.}

KSU has had a comprehensive research program since 1990 directed toward developing pawpaw as a new commercial tree fruit crop for Kentucky and the United States (Callaway, 1992). In Kentucky, alternative and potentially high-value cash crops, such as pawpaw, are being investigated for their production feasibility to help farmers diversify agricultural production away from tobacco. A significant obstacle in the development of any new crop is the dearth of scientific information available on how the crop grows and how best to grow the crop. In the case of pawpaw, scientifically based recommendations for commercial tree production did not exist. Much initial work by others involved adopting techniques/technologies used for other tree fruit crops, educated "best guesses," and trial and error. We have already made considerable progress toward production of robust, healthy trees in the greenhouse (Jones et al., 1995; Layne and Kwantes, 1995). Ongoing research projects at KSU include 1) determining factors that affect seed germination and seedling growth and development; 2) developing cultural recommendations for greenhouse and orchard production; 3) long-term evaluation of promising pawpaw clones and hybrids; 4) determining heritabilities for commercially important traits; and 5) characterizing the morphological and molecular variation in a diverse germplasm collection (Huang and Layne, 1996). Future efforts also will include developing techniques to 1) clonally mass-propagate desirable plants; 2) preserve diverse and promising germplasm; and 3) provide easy access to germplasm and information about germplasm, research findings, commercial recommendations, etc., to interested parties via an on-line database accessible through a World Wide Web Home Page on the Internet. These latter three objectives will be addressed by a newly funded FY95 USDA-1890 Institution Capacity Building Grant entitled "A Centralized Research Support System for Asimina Germplasm and Information," which establishes research partnerships among the KSU Community Research Service, KSU Cooperative Extension Service, USDA [Agricultural Research Service (ARS)-National Clonal Germplasm Repository (NCGR) (Corvallis, Ore.), National Agricultural Library and Germplasm Resource Information Network (GRIN) (Beltsville, Md.), and the Forest Service (Rhinelander, Wis.)], the Univ. of Kentucky, Stetson Univ. (DeLand, Fla.), PPF, and a private collector/ breeder.

\section{GERMPLASM}

In 1994 KSU was approved by the USDA-ARS-NCGR system to serve as the national repository for Asimina spp. germplasm in the United States (as a satellite of the NCGR in Corvallis, Ore.). The current collection of germplasm consists of trees planted in orchards and growing in greenhouses, and seeds in refrigerated storage. Four orchards at KSU contain $\approx 2800$ trees. These trees include grafted pawpaw varieties and seedlings from more than 70 distinct geographical regions of 17 states, including Arkansas, Georgia, Illinois, Indiana, Kentucky, Louisiana, Maryland, Mississippi, Missouri, Nebraska, New York, Ohio, Oklahoma, Pennsylvania, Tennessee, Virginia, and West Virginia. Trees range in age from 2 to 4 years. None of the trees are fruiting yet, although several flowered for the first time during Spring 1995. Also planted are A. parviflora seedlings and intra- and interspecific hybrid seedlings, including $A$. triloba $\times$ A. triloba, A. obovata $\times$ A. triloba, A. reticulata $\times$ A. triloba, and A. parviflora $\times$ A. triloba. In Fall 1995, a Regional Variety Trial (RVT) orchard (described below) was planted. In Spring 1996, 800 intraspecific hybrids of the PPF's advanced selections (cooperative research project with R.N. Peterson) were also field-planted. This is the largest collection of Asimina spp. germplasm in the world. We also are growing several potted specimens of the southern Asimina species, A. longifolia and A. tetramera (an endangered species), in the greenhouse. Several thousand pawpaw seeds of diverse origin as well as seed from tropical species, including Rollinia mucosa (Bail.), Annona squamosa $\times$ Annona cherimola (atemoya), and Annona squamosa, are held in cold storage. Germplasm evaluation and selection will be an ongoing, high-priority area of the KSU pawpaw research program.

\section{PAWPAW REGIONAL VARIETY TRIAL}

In 1993, PPF and KSU embarked on a joint venture to test within pawpaw's native range many of the commercially available, named pawpaw cultivars and PPF's advanced selections (Layne and Peterson, 1996). Orchards for RVT were planted in 16 different locations from Fall 1995 through Fall 1996 and consisted of 300 trees each. At each RVT site, eight replicate trees of each of the 28 grafted scion varieties will be tested in a randomized complete block design. Named cultivars that are secured for testing include: 'Middletown', 'Mitchell', 'NC-1', 'Overleese', 'PA-Golden', 'Sunflower', 'Taylor', 'Taytwo', 'Wells', and 'Wilson'. The other 18 clones to be evaluated originated in PPF orchards at the Univ. of Maryland experiment stations at Wye, Md., and Keedysville, Md. Seedling trees from local native sources were planted around the perimeter as a buffer against edge effects and to allow comparisons with local germplasm.

Identical orchards will be planted at the following institutions and locations: Univ. of Arkansas, Fayetteville; Purdue Univ., West Lafayette, Ind.; Iowa State Univ., Crawfordsville; Kentucky State Univ., Frankfort; Univ. of Kentucky, Princeton; Louisiana State Univ., Calhoun; Univ. of Maryland, Keedysville; Univ. of Nebraska, Lincoln; Cornell Univ., Ithaca; North Carolina State Univ., Raleigh; Ohio State Univ., Piketon; Oregon State Univ., Corvallis-outside of native range; Clemson Univ., Clemson, S.C.; and the Univ. of Tennessee, Knoxville. An orchard of nonidentical design was planted at Florida State Univ., Tallahassee. Additional sites in Connecticut and Chile are being contemplated. The Institute of Forestry, Chinese Academy of Forestry, Beijing, will be the international site.

Orchard performance to be examined at each RVT site will include climatic factors, culture, pests, growth, flowering, yield, and fruit characteristics. Trees will be evaluated for several years for yield, year-to-year consistency, regional suitability, etc. At the end of several fruiting seasons, regional recommendations will be made. Each site will serve as a regional demonstration for growers and nursery operators, and will serve public education/ extension purposes. Once trees begin fruiting, annual RVT cooperator meetings will rotate from site to site for research updates and plot evaluations/tours. 


\section{FIRST INTERNATIONAL PAWPAW CONFERENCE}

The first International Pawpaw Conference hosted by PPF was held 9-11 Sept. 1994 at the Western Maryland Research and Education Center (WMREC), Keedysville. There are some 700 openpollinated, 12-year-old, bearing pawpaw trees at WMREC. Several cultivars and advanced PPF selections to be planted in the RVT were available for harvest and taste evaluation during this conference. Those in attendance included research scientists, nursery operators, horticulturists, amateur naturalists, a perfume chemist, and several freelance writers. Several presentations were made regarding pawpaw research in nutrition, reproductive biology, germination/container culture, early growth enhancement, transplanting techniques, and anticancer drug development. In addition, workshops were held on evaluating fruit, taste testing, cleaning seed, and grafting/budding techniques. Participants also were treated to a presentation and taste evaluation comparing many of the tropical Annonaceous relatives of pawpaw. A second international conference will be held at KSU in Sept. 1997.

\section{CONCLUSIONS}

Considerable efforts are currently underway at KSU and Purdue Univ. (and others will soon be implemented at several academic institutions through RVT cooperation) to overcome the horticultural limitations to developing pawpaw as a new commercial fruit crop. In addition to the aforementioned research, several additional areas will also require concerted attention: 1 ) developing postharvest techniques to maximize shelf life and maintain quality of fresh fruit; 2) developing processed pawpaw food products; 3) developing commercial/retail markets and promotion/public education strategies; 4) developing commercially feasible techniques for a renewable pawpaw biomass production system; and 5) developing an understanding of pollination biology and strategy to ensure adequate fruit production. As these and other questions are addressed and answered, pawpaw will almost certainly become a profitable fruit crop to grow in the United States and it may gain popularity similar to kiwifruit [Actinidia deliciosa (A. Chev.) C.F. Liang et Ferguson] in the future.

\section{Literature Cited}

American Forestry Association. 1990. National register of champion trees. Amer. For. 96(1-2):29.

Arnold, M.A. and D.K. Struve. 1993. Root distribution and mineral uptake of coarse-rooted trees grown in cupric hydroxide-treated containers. HortScience 28:988-992.

Bailey, L.H. 1960. The standard cyclopedia of horticulture. vol. 1. MacMillan, New York.

Bejoy, M. and M. Hariharan. 1992. In vitro plantlet differentiation in Annona muricata. Plant Cell Tissue Organ Culture 31:245-247.

Callaway, M.B. 1992. Current research for the commercial development of pawpaw [Asimina triloba (L.) Dunal]. HortScience 27:90, 191.

Damman, A.J. 1986. Effects of seasonal changes in leaf quality and abundance of natural enemies on the insect herbivores of pawpaws. PhD Diss., Cornell Univ., Ithaca, N.Y.

Darrow, G.M. 1975. Minor temperate fruits, p. 276-277. In: J. Janick and J.N. Moore (eds.). Advances in fruit breeding. Purdue Univ. Press, West Lafayette, Ind.

Filson, J. 1784. The discovery, settlement, and present state of Kentucke. Originally published in Wilmington, Del. Republished in 1966 as part of the Great Americana Series, Readex Microprint Corp., Chester, Vt.

Finneseth, C.L.H., D.R. Layne, and R.L. Geneve. 1996. Morphological development of pawpaw [Asimina triloba (L.) Dunal] during seed germination and seedling emergence. HortScience 31:633. (Abstr.)

Gale, F. 1994. What tobacco farming means to local economies. U.S. Dept. Agr.-Econ. Res. Serv. Agr. Econ. Rpt. 694

Gould, H.P. 1939. The native pawpaw. U.S. Dept. Agr. Leaflet 179:1-6.

Hickman, J.W. 1985. Asimina triloba (pawpaw) propagation by cuttings. Pomona 18:284

Huang, H. and D.R. Layne. 1996. Allozyme variation and geographic differentiation in pawpaw [Asimina triloba (L.) Dunal]. HortScience 31:592. (Abstr.)

Jones, L., D.R. Layne, and M.G. Kwantes. 1995. Pawpaw (Asimina triloba) seedling growth and development: Influence of incident light intensity and fertilization regime. HortScience 30:437.

Jones, S.C. and D.R. Layne. 1996. Cooking with pawpaws. Kentucky State Univ. Pawpaw Ext. Bul. 001. (In press.)

Jordan, M. 1988. Multiple shoot formation and rhizogenesis from cherimola (Annona cherimola L.) hypocotyls and petiole explants. Gartenbauwissenschaft 53:234-237.

Jordan, M., L. Iturriaga, C. Roverar, and A. Goreux. 1991. Promotion of Annona cherimola in vitro shoot morphogenesis as influenced by antioxidants. Gartenbauwissenschaft 56:224-227.

Kral, R. 1960. A revision of Asimina and Deeringothamnus (Annonaceae). Brittonia 12:233-278.

Krause, G.H. 1988. Photoinhibition of photosynthesis. An evaluation of damaging and protective mechanisms. Physiol. Plant. 74:566-574.

Lawson, J. 1709 (reprinted in 1967). The natural history of Carolina, p. 111. In: H.T. Lefler (ed.). A new voyage to Carolina. Univ. of North Carolina Press, Chapel Hill.

Layne, D.R. and M.G. Kwantes. 1995. The influence of root-zone temperature and fertilization regime on early growth and development of pawpaw (Asimina triloba Dunal) seedlings. HortScience 30:870.

Layne, D.R. and R.N. Peterson. 1996. The pawpaw regional variety trial (RVT): Background, rationale and early data. HortScience 31:667. (Abstr.)

Lewis, M. and W. Clark. 1806. [reprinted in 1981; B. DeVoto (ed.)]. The journals of Lewis and Clark. Houghton Mifflin Co., Boston.

Owens, L.(publisher). 1994a. Hatfield, Ky., W.Va. battle for tourist dollars: Key happenings in the Hatfield-McCoy feud. Lexington Herald Leader 9 Oct. 1994. Sect. B6.

Owens, L (publisher). 1994b. Hooked on tobacco II: Kentucky's burley faces global threat. A new world of competition. Lexington Herald Leader 4 Dec. 1994. Sect. A1

McGrath, M.J. and C. Karahadian. 1994. Evaluation of physical, chemical, and sensory properties of pawpaw fruit (Asimina triloba) as indicators of ripeness. J. Agr. Food Chem. 42:968-974.

McLaughlin, J.L. and Y.-H. Hui. 1993. Chemotherapeutically active acetogenins. U.S. Patent 5,229,419.

Mikolajczak, K.L., J.L. McLaughlin, and J.K. Rupprecht. 1988. Control of pests with annonaceous acetogenins. U.S. Patent 4,721,727.

Nair, S., P.K. Gupta, and A.F. Mascarenhas. 1983. Haploid plants from in vitro anther culture of Annona squamosa Linn. Plant Cell Rpt. 2:198-200.

Nair, S., P.K. Gupta, and A.F. Mascarenhas. 1984a. In vitro propagation of Annona hybrid (Annona squamosa L. X Annona cherimola L.). Indian J. Hort. 41:160-165.

Nair, S., P.K. Gupta, M.V. Shirgurkar, and A.F. Mascarenhas. 1984b. In vitro organogenesis from leaf explants of Annona squamosa Linn. Plant Cell Tissue Organ Culture 3:29-40.

Nair, S., M.V. Shirgurkar, and A.F. Mascarenhas. 1986. Studies on endosperm culture of Annona squamosa Linn. Plant Cell Rpt. 5:132-135.

Peterson, R.N. 1991. Pawpaw (Asimina). In: J.N. Moore and J.R. Ballington (eds.). Genetic resources of temperate fruit and nut trees. Acta Hort. 290:567-600.

Peterson, R.N., J.P. Cherry, and J.G. Simmons. 1982. Composition of pawpaw (Asimina triloba) fruit. Annu. Rpt. Northern Nut Growers Assn. 77:97106.

Pickering, C. 1879. Chronological history of plants, p. 881. Little, Brown, and Co., Boston.

Pierik, R.L.M. 1989. In vitro culture of higher plants. 2nd ed. Martinus Nijhoff, Dordrecht, The Netherlands.

Rasai, S., A.S. Kantharajah, and W.A. Dodd. 1994. The effect of growth regulators, source of explants and irradiance on in vitro regeneration of atemoya. Austral. J. Plant Physiol. 21:333-340.

Rupprecht, J.K., C.-J. Chang, J.M. Cassady, and J.L. McLauglin. 1986. Asimicin, A new cytotoxic and pesticidal acetogenin from the pawpaw, Asimina triloba (Annonaceae). Heterocycles 24:1197-1201.

Sargent, C.S. 1890. Silva of North America. Houghton Mifflin Co., New York.

Shiota, H. 1991. Volatile components of pawpaw fruit (Asimina triloba). J. Agr. Food Chem. 39:1631-1635.

U.S. Dept. of Agriculture. 1948. Asimina triloba (L.) Dunal, pawpaw, p. 92. In: Woody plant seed manual. U.S. Dept. Agr., Washington, D.C., Misc. Publ. 654.

Vines, R.A. 1960. Trees, shrubs and woody vines of the southwest. Univ. of Texas Press, Austin.

Wilson, M.F. and D.W. Schemske. 1980. Pollinator limitation, fruit production, and floral display in pawpaw (Asimina triloba). Bul. Torrey Bot. Club 107:401-408.

Zhao, G.X., L.R. Miesbauer, D.L. Smith, and J.L. McLaughlin. 1994. Asimin, asiminacin, and asiminecin: Novel highly cytotoxic asimicin isomers from Asimina triloba. J. Med. Chem. 37:1971-1976. 


\section{Babaco (Carica pentagona Heilb.): A Possible Crop for the Greenhouse}

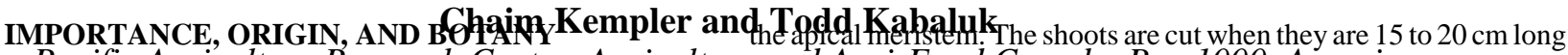

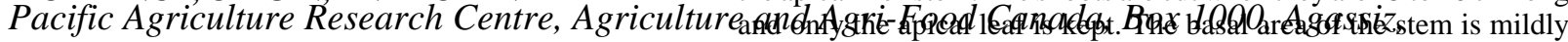

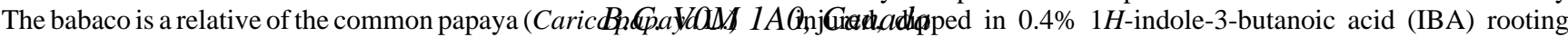
that is native to the highland regions of Ecuador and Colombia. It is believed to be a natural hybrid of $C$. pubescens Lenne et Koch and $C$. stipulata Badillo (Horovitz and Jimenez, 1967), and the full name denoting its hybrid status is Carica $\times$ heilbornii Badillo n.m. pentagona (Heilborn). The plant is sterile and only reproducible by asexual means. Babaco is one of several "mountain papayas," the related species being C. pubescens (chamburo), C. stipulata (siglalon), $C$. monoica Desf. (Col de Monte), and C. goudotiana (Tr. and Pl.) Solms (papauelo), all resembling the tropical papaya in appearance and having similar cultivation requirements. They are regarded as unexploited crops capable of being cultivated in subtropical climates and as possible genetic sources for crosses with the tropical papaya to extend the range of $C$. papaya into subtropical regions (Dawes and Pringle, 1983; National Research Council, 1989).

Babaco is the most promising of the highland Carica species and hybrids mainly because of its large, seedless fruit. In the highlands of Ecuador, where it is most commonly found, it grows between 1800 and $3000 \mathrm{~m}$ above sea level (Dawes and Pringle, 1983). The plant culture of babaco in this region has a long history. In the local markets, babaco is currently found as fresh fruit and also in jams and juices. Because it is propagated by cuttings, the distribution of babaco from its center of origin has been slow, and only recently has it been cultivated in neighboring countries.

The babaco plant is slender-stemmed, herbaceous, and treelike, reaching $2 \mathrm{~m}$ in height. It resembles the papaya plant. The large palmate leaves are found near the apex of the trunk. Flowering occurs in the leaf axils on the trunk shortly after planting (Fig. 1). Babaco is dioecious; there are only pistillate plants that are cross-incompatible with related species (Horovitz and Jimenez, 1967; Manshardt and Wenslaff, 1989). Five-sided fruit are set parthenocarpically and can grow to $2 \mathrm{~kg}$ in weight, $40 \mathrm{~cm}$ in length, and $15 \mathrm{~cm}$ across (Kempler et al., 1993; Morley-Bunker, 1986) (Fig. 2). The fruit hang against the trunk (Fig. 3) and take 7 to 10 months from flowering to show yellow pigmentation as they begin to ripen.

International recognition of the babaco began in 1973 when researchers from the Dept. of Scientific and Industrial Research, New Zealand, imported cuttings from Ecuador (Dawes and Pringle, 1983). New Zealand's ability to promote sales of exotic fruits led to the creation of foreign markets and commercial production of babaco in New Zealand, Italy, Spain, Israel, United Kingdom (Guernsey), and the United States (California).

\section{ADAPTABILITY AND GROWING CONDITIONS}

Endt (1986) reported that greenhouse cultivation, as opposed to field culture, is necessary to produce high-quality babaco fruit with soft, edible skin. Fortunately, the plants are easily cultivated under greenhouse conditions (Evequoz, 1990; Kempler et al., 1993) (Fig. 2). Establishment of a crop is simple, and propagation has been achieved by rooting axillary shoots. Stem sections root poorly. The opening of axillary buds and subsequent shoot growth is stimulated by removing

Received for publication 30 Sept. 1995. Accepted for publication 23 Oct. 1995. Pacific Agriculture Research Centre (Agassiz) Contribution no. 538. The cost of publishing this paper was defrayed in part by the payment of page charges. Under postal regulations, this paper therefore must be hereby marked advertisement solely to indicate this fact. powder, and planted into a suitable rooting medium such as a 1 peat : 1 perlite : 1 sand mix and placed under intermittent mist. Cuttings can be ready for transplanting within 3 weeks.

In contrast to the tropical papaya, babaco requires a cool subtropical climate. Evequoz (1990) reported a minimum permissible air temperature requirement of $12 \mathrm{C}$ under cultivation. Long (1988) recommended greenhouse minimums of $10 \mathrm{C}$ at night, $12 \mathrm{C}$ during the day, $12 \mathrm{C}$ for roots, and $18 \mathrm{C}$ for fruit to ripen quickly and uniformly. Excessive fluctuations in day and night temperatures, or low night temperature, even for a short time, caused babaco fruit to mature misshapen, with a rough pitted skin.

The flowering habit of babaco is indeterminate. Under greenhouse conditions, plant growth during the winter months (October-March at $49^{\circ} \mathrm{N}$ ) is slow, and flowers senesce and fail to set fruit (Evequoz, 1990; Kempler et al., 1993). Under field culture in Ecuador, the trees begin cropping 10 months after planting and continue bearing for 6 months, yielding about 40 fruit/tree, each fruit weighing 1 to $1.4 \mathrm{~kg}$ (Oosten, 1986). Plants cultivated in the greenhouse by Kempler et al. (1993) produced $32 \mathrm{~kg}$ fruit $/ \mathrm{m}^{2}$ after 16 months when planted at 0.8 plants $/ \mathrm{m}^{2}$, and $25 \mathrm{~kg} \cdot \mathrm{m}^{-2}$ after 12 months spaced at three plants $/ \mathrm{m}^{2}$. Evequoz (1990) reported a yield of $60 \mathrm{~kg} /$ plant 18 months after planting at

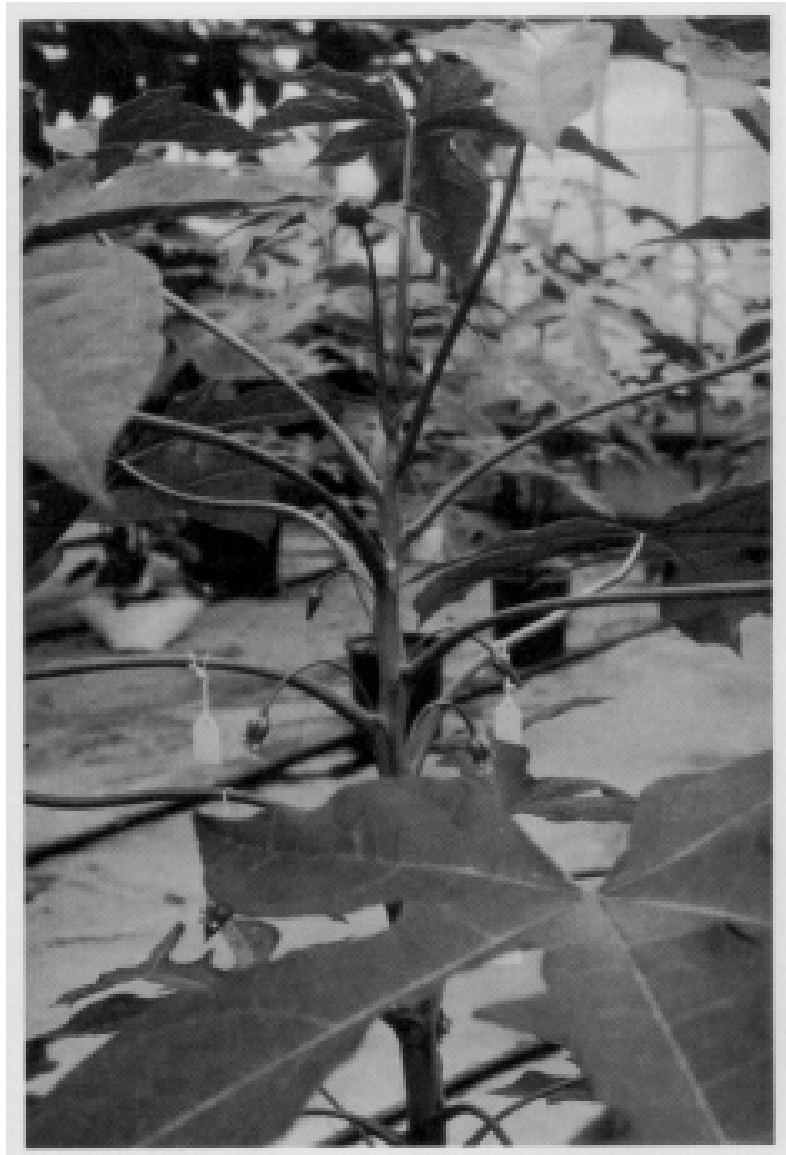

Fig. 1. Flowers and immature parthenocarpically set fruit growing from the axils of a babaco plant 
densities ranging from 0.6 to 1 plant $/ \mathrm{m}^{2}$. Because of the heavy fruit load, a support system for the plants was required.

Fruit size is determined by fruit position on the stem and stem vigor. Fruit size decreases with increased distance from the stem base. Smaller than normal fruit can be obtained by growing plants at high densities (Kempler et al., 1993), which is easily accommodated due to the plant's slender growth habit. The fruit begins to mature with a gradual color change from green to yellow (Fig. 1). If harvest is delayed, the fruit stalk will abscise and the fruit will drop and bruise. The delicate-skinned fruit is picked with a short stalk and must be handled carefully. In the greenhouse at lat. $49^{\circ} \mathrm{N}$, ripening begins in November (March planting) and harvest continues until June. During this period, new flowers and fruits are produced from April to September and these fruits will begin ripening in November; the main trunk is cut back above the last-formed fruit as new flowers senesce (October to March). After the second crop, ending in March, plants either are rejuvenated by inducing axillary growth at the base of the plant or replaced with new plants from axillary cuttings.

\section{PAST AND PRESENT RESEARCH}

Research on babaco has focused primarily on propagation methods, with emphasis on micropropagation. Cohen and Cooper (1982) developed a method of micropropagating node segments, and Jordan et al. (1990) described a method of micropropagating axillary buds. Pocock (1983) outlined a procedure for transferring plants from culture media to field establishment, and Evequoz (1990) used tissue culture-derived plants to establish a crop under glass for a production trial. Soria (1983) grafted axillary buds onto 6-month-old stems of $C$. pubescens and reported a $90 \%$ take.

Kempler et al. (1993) and Evequoz (1990) described methods for greenhouse cultivation of babaco in pots and in the ground, respectively. Both reports appear to be practical guidelines for commercial production of the crop. Kempler et al. (1993) grew plants ranging in density from 0.5 to 4 plants $/ \mathrm{m}^{2}$ and reported that, with increasing density, the number of fruit per plant, yield per plant, and fruit size decreased, while yield per square meter, number of fruit per square

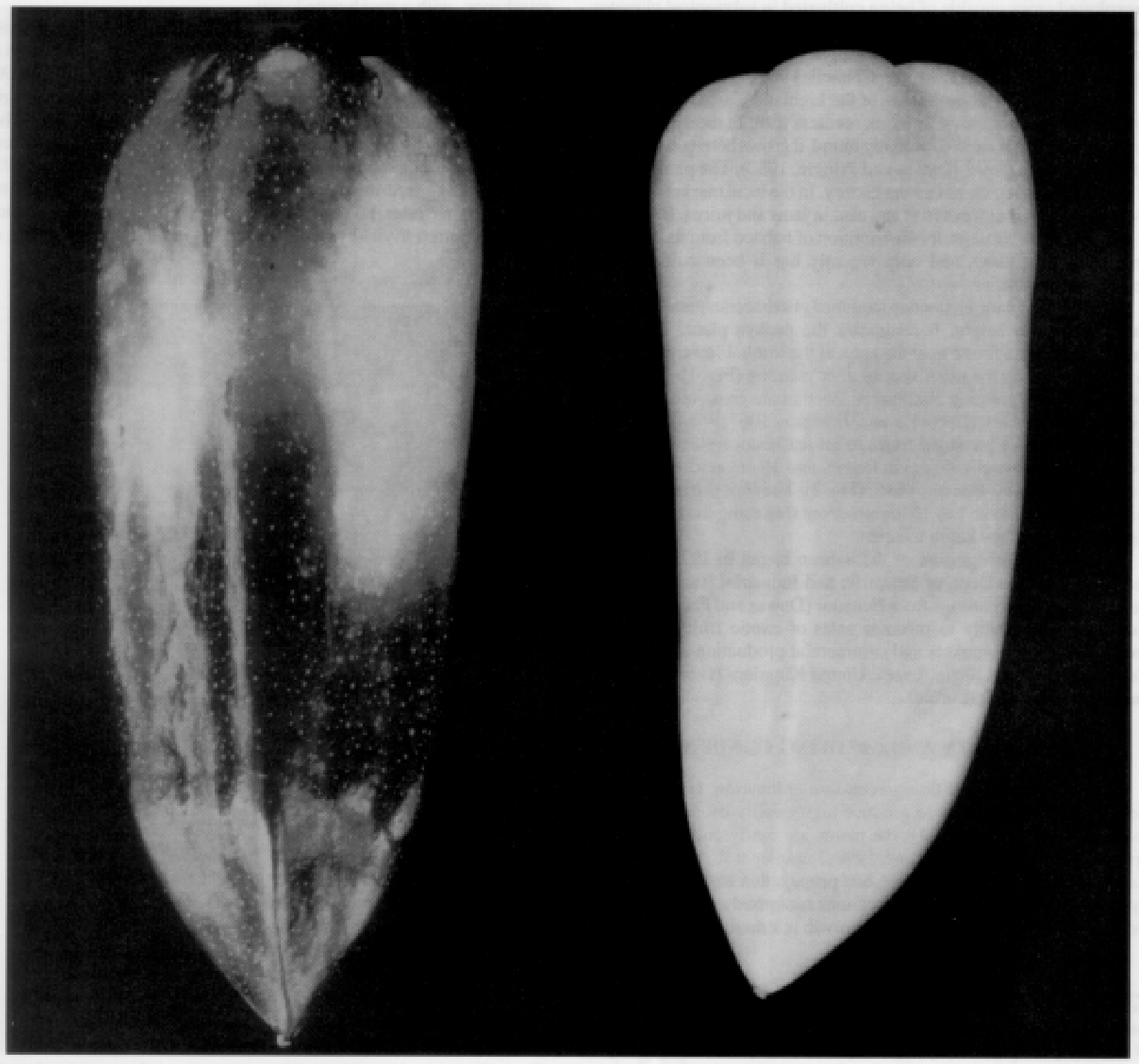

Fig. 2. Babaco fruit (left) ready for harvest (dark areas are green) and (right) fully ripened. 


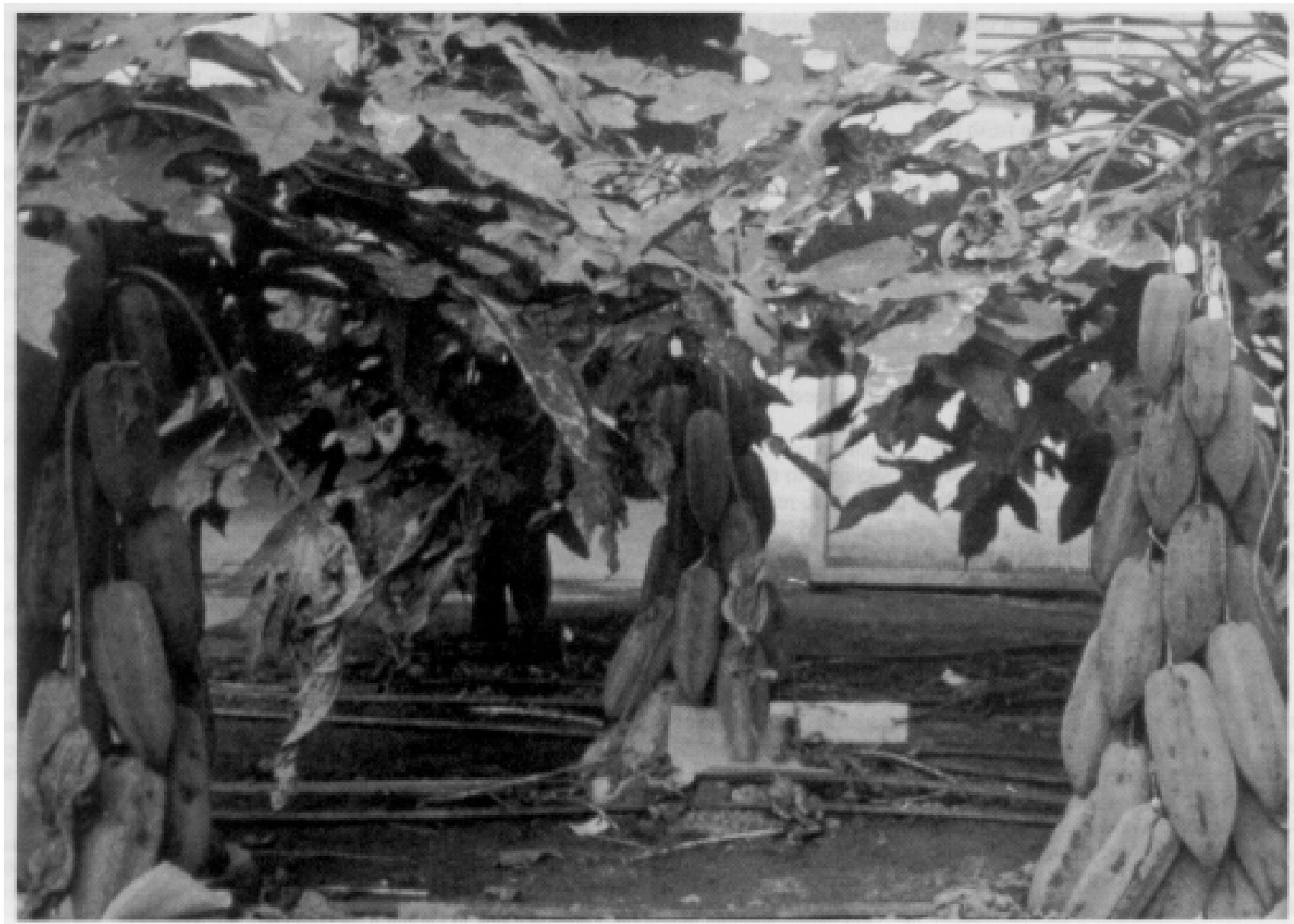

Fig. 3. Full load of fruit on babaco plants growing in the ground in a plastic house. With this amount of fruit, plants need support from wires strung above or from long stakes in the ground.

meter, and days to harvest increased. They also compared growing media and the effect of number of stems per plant, and described the flowering and fruiting habit of the plants. Evequoz (1990) detailed the changes in fruit load and size through 1 year of cultivation. Cossio (1985) described cultural requirements for growing babaco in New Zealand and Australia.

The postharvest behavior of babaco, particularly ethylene production, was studied by Mencarelli et al. (1990). They also reported storage conditions that either sustained and enhanced fruit quality or were detrimental to the fruit. Harman (1983) found that the fruit is climacteric; respiration and ethylene production increase as the fruit ripens. He also reported that fruit are chilling-sensitive below $3 \mathrm{C}$ and that fruit stored at $10 \mathrm{C}$ ripened during storage and rapidly succumbed to fungal rots. According to Harman (1983) and Morley-Bunker (1986), babaco fruit can be safely stored for 5 weeks at 6C.

Wills et al. (1985) presented a detailed nutritional analysis of babaco fruit purchased from two retail outlets in Sydney, Australia, and reported the fruit consisted of $94 \%$ water; $3.1 \%$ sugars; $1.3 \%$ dietary fiber, ash, and proteins; and $\approx 0.6 \%$ organic acids. The energy contained in the fruit was $83 \mathrm{~kJ} \cdot 100 \mathrm{~g}^{-1}$. The only vitamin that was found in any significant amount was vitamin $\mathrm{C}$ at $23 \mathrm{mg} \cdot 100 \mathrm{~g}^{-1}$. Potassium was present at $140 \mathrm{mg} \cdot 100 \mathrm{~g}^{-1}$. Shaw et al. (1985) identified 32 chemical components in babaco fruit using gas chromatography (GC) and GC-mass spectroscopy (GC-MS) and suggested ethylbutanoate and ethyl hexanoate as important contributors to the unique flavor. Barbeni et al. (1990) used GC and GC-MS to identify 9 hydrocarbons, 20 alcohols, 9 carbonyls, 9 acids, 60 esters, 3 lactones, 2 sulfur compounds, and 7 miscellaneous components in the fruit. They listed butan-1-ol and hexan-1-ol as the two major components, but suggested aroma and flavor were a collective effect of many compounds.
A few reports on pests and diseases have alerted prospective growers to problems that might be encountered. Both Menzies and Kempler (1991) and Evequoz (1990) reported that powdery mildew (Oidium caricae-papayae Yen) infected leaves of babaco and caused premature yellowing of the leaves and eventual abscission. Barba and Giordano (1989) reported that leaf-yellowing was caused by a strain of papaya mosaic virus that affected growth and yield. A foot and root rot caused by Erwinia has been reported by Babelegoto et al. (1989), thrips damage by Willers (1991), and damage caused by the nematode Meloidogyne incognita (Kafoid and White) Chitwood by Tacconi and Pisi (1988). Control of these pests and diseases likely could follow the methods used for other greenhouse crops, although no pesticides are registered for babaco at this time.

Because plant improvement via conventional breeding methods is impossible, somatic embryogenesis or organogenesis can be the alternative breeding method for improving this crop. Vega de Rojas and Kitto (1991) developed a scheme for recovering babaco plants from ovular callus that could allow the regeneration of somaclonal variants for selecting new babaco types with pest resistance, cold hardiness, or enhanced fruit characteristics.

\section{COMMERCIAL POTENTIAL}

Babaco has several characteristics that are beneficial to its commercialization. It is easily propagated and grown, enticing a wider range of growers, and requires less labor input than the average greenhouse crop. It can easily produce 320 t fruit/ha, so economic production is not a problem (Oosten, 1986). Its fruit are highly attractive with a captivating, pleasant aroma when ripe-qualities that would certainly be noticed by consumers in the supermarket. As the fruit are completely seedless, they are easily eaten in their entirety. The 
skin is very soft and palatable, a characteristic exclusive to greenhouse-grown fruit. As the sugar content is low, marketability would likely improve by increasing fruit sugars. The soluble solids concentration is $3 \%$ to $4 \%$, so sugar must be added to fruit products, such as jams and juices, and even to the fresh fruit.

Growers who have actively produced babaco and pursued markets have been successful. New Zealand, U.K. (Guernsey), and Italy all have been successful in creating export markets for fresh fruit. Babaco grower associations have been formed and have been responsible for controlling the quality of the exported fruit. With the sharp production increase in New Zealand in 1986, inexperienced growers were producing inferior fruit, resulting in negative public response and a drop in price (Endt, 1986). A similar situation occurred in Italy, but in addition to rapid overproduction and the subsequent decline in fruit quality, their outdoor-grown fruit had a tougher skin — an undesirable condition for the fresh-fruit market.

Market development and quality control must coincide with the cultivation of babaco because it is relatively unknown to the general public, and because once it becomes introduced, it must appear presentable and be useful. With skillful and organized planning for production and marketing, it appears that babaco can be an economically rewarding crop to grow.

\section{CONCLUSION}

Babaco is a promising papaya relative that produces large, aromatic, flavorful fruit. It is easily propagated and suitable for greenhouse cultivation. Enough reports exist for prospective growers to produce a crop where fruit size and yield can be controlled by manipulating cultural conditions. Although babaco is parthenocarpic, it is possible to improve the plant through somatic embryogenesis or organogenesis, or by discovering natural mutations. Tissue culture techniques exist for rapid propagation. Some information is available on the postharvest behavior of babaco, and high-quality fruit for export markets can be provided. Pests and diseases of babaco have been reported and may be encountered when growing the crop. Babaco has been successfully grown and marketed by several countries, but its commercial potential has yet to be realized. Active marketing strategies aimed at making babaco a more commercially visible fruit are needed.

Babaco is a subtropical fruit, which, in the temperate zone, is a promising crop for greenhouse cultivation. It is easily propagated and grown, and with minimal labor input during the growing period, yields can be remarkably high. Highly attractive, particularly in appearance and fragrance, it is reasonable to expect that with some effort, stable high-value markets for babaco might be created. Its successful cultivation in several countries throughout the world has provided a basis for further development and marketing.

Relatively little research has been conducted on the babaco, but enough reports exist to provide potential growers with general information on cultural requirements, including temperatures, media, planting density, postharvest handling, and potential diseases. Some research on the effect of light intensity for continuous cropping throughout the year is necessary. Improving the sweetness of babaco fruit could elevate its popularity to a well-recognized tropical fruit.

\section{Literature Cited}

Babelgoto, N.M., F. Ciccarese, A. Caponero, and M. Cirulli. 1989. A foot and root rot of babaco caused by Erwinia carotovora. Informatore-Fitopatologico 39(9):55-58.

Barba, M. and P. Giordano. 1989. Babaco yellow mosaic virus in Italy. Informatore-Fitopatologico 39(3):58-60.

Barbeni, M., P.A. Guarda, M. Villa, P. Cabella, F. Pivetti, and F. Ciaccio. 1990. Identification and sensory analysis of volatile constituents of babaco fruit (Carica pentagona (Heilborn)). J. Flavour Fragrance 5(1):27-32.

Cohen, D. and P.A. Cooper. 1982. Micropropagation of babaco. A Carica hybrid from Ecuador, p. 743-744. In: A. Fujiwara (ed.). Plant tissue culture 1982. Fifth Intl. Congr. Plant Tissue and Cell Culture. Japanese Assn. Plant Tissue Culture, Tokyo.

Cossio, F. 1985. Babaco, a fruit of the near future? Informatore-Agario 41:40, $63-67$.

Dawes, S.N. and G.J. Pringle. 1983. Subtropical fruits from South and Central America, p. 136. In: G.S. Smith and H.C. Wratt (eds.). Plant breeding in New Zealand. Butterworths, Wellington, New Zealand.

Endt, D.J.W. 1986. Growing interest in babaco worldwide. Orchardist of New Zealand. September.

Evequoz, N. 1990. First results for babaco culture trial. Revue Suisse Vitic. Arbor. Hort. 22(2):137-141.

Harman, J.E. 1983. Preliminary studies on the postharvest physiology and storage of babaco fruit (Carica $\times$ heilbornii Badillonm. pentagona (heilborn) Badillo). N.Z. J. Agr. Res. 26:237-243.

Horovitz, S. and H. Jimenez. 1967. Cruzamientos interespecificos e intergenericos en caricaceas y sus implicaciones fitotencicas. Agronomia Tropical (Venezuela) 17:323-343.

Jordan, M., P. Arce, and C. Roveraro. 1990. In vitro propagation of some fruit species grown in Chile. Ciencia-e-Investigacion-Agraria 17(3):111-116.

Kempler, C., J.T. Kabaluk, and M. Nelson. 1993. Greenhouse cultivation of babaco (Carica $\times$ heilbornii Badillo n.m. pentagona (Heilborn)): Effect of media, container size, stem number, and plant density. N.Z. J. Crop Hort. Sci. 21:273-277.

Long, E. 1988. A flavour of the tropics. Grower 21:51-52.

Manshardt, R.M. and T.F. Wenslaff. 1989. Interspecific hybridization of papaya with other Carica species. J. Amer. Soc. Hort. Sci. 114:689-694.

Mencarelli, F., F. Fontana, and R. Massantini. 1990. Postharvest behaviour and chilling injury in babaco fruit. Acta Hort. 269:223-231.

Menzies, J.G. and C. Kempler. 1991. Powdery mildew of babaco at Agassiz, British Columbia. Can. Plant Dis. Survey 71(1):43-46.

Morley-Bunker, M. 1986. Miscellaneous and minor fruit crops, p. 261-262. In: D. Jackson (ed.). Temperate and subtropical fruit production. Butterworths, Wellington, New Zealand.

National Research Council. 1989. Babaco, p. 257-261. In: F.R. Ruskin (ed.). Lost crops of the Incas: Little-known plants of the Andes with promise for worldwide cultivation. National Academy Press, Washington, D.C.

van Oosten, H.J. 1986. A meadow orchard with Carica pentagona (babaco). Acta Hort. 160:341.

Pocock, S. 1983. Procedures and problems associated with the transfer of tissue-cultured plants. Proc. Intl. Plant Propagators' Soc. 33:316-320.

Shaw, G.J., J.M. Allen, and F.R. Visser. 1985. Volatile flavour components of babaco fruit (Carica pentagona (Heilborn)). J. Agr. FoodChem. 33:795-797.

Soria, V.M. 1983. Propagation of babaco (Carica pentagoNA) by grafting. Turrialba 33(2):215-217.

Tacconi, R. and A. Pisi. 1988. Damage caused by nematode to babaco crop. Terra-e-Vita 2:105-106.

Vega de Rojas, R. and S.L. Kitto. 1991. Regeneration of babaco (Carica pentagona) from ovular callus. J. Amer. Soc. Hort. Sci. 116(4):747-752.

Willers, P. 1991. Thrips damage to babaco. Inligtingsbulletin 226:10.

Wills, R.B.H., J.S.K. Lim, and H. Greenfield. 1985. Nutrient composition of babaco fruit (Carica pentagona). J. Plant Foods 6:165-166. 


\title{
Guava (Psidium guajava L.): An Exotic Tree Fruit with Potential in the Southeastern United States
}

\author{
Umedi L. Yadava \\ Agricultural Research Station, Fort Valley State College, Fort Valley, GA 31030-3298
}

\begin{abstract}
Guava is one of the 50 most well-known edible tree fruits of the tropical and subtropical climates. It is often referred to as the "poorman's fruit" or "apple of the tropics," and is almost universally known by its English name. However, it also carries diverse vernacular names in various countries of the world: amarood, jamphal, jamrukh, piyara, sapari, etc. in India; guyava and guayaba in Spain; guyave (the plant goyavier) in France; guyaaba in Holland; goiaba in Portugal; kuawa in Hawaii; abas in Guam; araca in Brazil; jambu batu in Malaya; and bayabas in the Philippines; while in Mexico and Central America, the Indians call it pichi, posh, enandi, etc. (Jaisval and Amin, 1992; Martin et al., 1987; Morton, 1987). The guava tree is native to tropical America, but it is cultivated in every tropical and subtropical country of the world (Samson, 1986). Although very cheap in the countries of production wherever grown, it is a delicious fruit that is highly nutritious and exceptionally rich in ascorbic acid (vitamin C) and several minerals useful for human health (Wilson, 1980). To those fruit lovers who are familiar with its penetrating aroma, guava is considered one of the most delicious and fascinating fruits (Menzel, 1985). Besides its exceptionally high nutritive values, guava also is a prolific and regular-bearing tree fruit that could produce fruit yearround (Thonte and Chakrawar, 1982). Guava plants exceed most of the tropical and subtropical fruit trees in adaptability, productivity, and tolerance to cold temperatures bordering freezing and light frosts. The guava is successfully cultivated in a wide range of environmental and edaphic conditions because of its tolerance to drought and salinity as compared to most of the warm-climate fruit plants (Samson, 1986). It is commercially cultivated in many countries around the world, including India, South Africa, Brazil, Cuba, Venezuela, New Zealand, the Philippines, and Haiti. Hawaii, Florida, and California are the main producers in the United States. For the past several years, we have been growing guava successfully under a protective structure in the field at the Agricultural Research Station, Fort Valley State College (FVSC). The trees, grown in the field from seedlings, annually have produced an impressive number of large fruit of good eating quality. The harvesting period of mature and tree-ripe fruit in the central Georgia area extends from late August to the middle of January. Ongoing research investigations at FVSC emphasize production management under protection and tissue culture biotechnology to develop and/or improve desirable characteristics, such as cold hardiness, seedlessness, micropropagation, tree dwarfing, and fruit maturity and quality.
\end{abstract}

\section{ITS ORIGIN}

The guava, a member of the Myrtaceae family, is native to tropical America, stretching from Mexico to Peru. In most of the countries of its origin, guava is commercially cultivated and also thrives well in the wild. Although guava plant was domesticated more than 2000 years ago, it was not until $1526 \mathrm{AD}$ when its first regular cultivation was reported in the West Indies (Cobley, 1976; Morton, 1987). It was introduced by the Spaniards into the Philippines and through the Portuguese into India by the early seventeenth century (Menzel, 1985). In later years, it quickly spread to most of the tropical and subtropical areas of the world, where it became naturalized to the extent that, in some countries and certain growing regions, the guava plant is being considered a noxious weed.

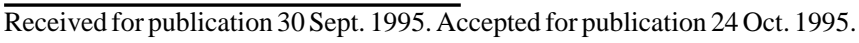
The cost of publishing this paper was defrayed in part by the payment of page charges. Under postal regulations, this paper therefore must be hereby marked advertisement solely to indicate this fact.

\section{ITS BOTANY}

The guava plant shares the Myrtaceae family with such important crop species as allspice [Pimenta dioica (L.) Merr.], cinnamon (Cinnamomum aromaticum Nees), clove [Syzygium aromaticum (L.) Merr. \& Perry], eucalyptus (Eucalyptus spp. L.), feijoa (Feijoa sellowiana Berg.), jamun or jambolan (Syzygium cumini Skeels), nutmeg [Myristica fragrans (L.) Houtt.], and rose apple (Syzygium aqueum Burm. f.). There are 150 species of Psidium, most of which are fruit-bearing trees native to tropical and subtropical America.

The guava plant, which grows symmetrically dome-shaped with a broad, spreading, low-branching canopy, is a shallow-rooted small tree 3 to $10 \mathrm{~m}$ in height, branching close to the ground, and often heavily suckering from the base of the trunk. The smooth and green to reddish-brown bark on older branches and trunk peels off in thin flakes. The four-angled young twigs of guava plants are easily recognizable. The simple leaves are always opposite, 10 to $15 \mathrm{~cm}$ long, oval to oblong-elliptic, smooth, and light green. The bisexual or perfect epigynous flowers, measuring from 25 to $30 \mathrm{~mm}$ in diameter with four incurved white petals and a large tuft of white stamens tipped with yellowish anthers, are borne solitary or in clusters of two or three in axils of leaves on new growth from mature wood (Fig. 1). The guava flower produces numerous stamens and plentiful pollen. Self-pollination is conspicuous $(60 \%$ to $75 \%$ ) since even isolated trees produce satisfactory crop; however, the distribution of cross-pollination, which is carried out mainly by insects and bees, is estimated to be $\approx 35 \%$ (Menzel, 1985).

The guava fruit is an ovoid, spherical, or pyriform berry topped by calyx lobes, measuring 4 to $12 \mathrm{~cm}$ in diameter and weighing from 100 to $450 \mathrm{~g}$ (the largest guava fruit harvested at FVSC during the 1992, 1993, and 1994 growing seasons weighed 597, 756, and $862 \mathrm{~g}$, respectively). The guava has a thin and light-green or bright-yellow (including various combinations thereof) skin. The color of the flesh varies from white through shades of salmon to deep pink and red, cream, or yellow (Fig. 1). Flesh recovery for most of the table cultivars ranges between $80 \%$ and $96 \%$. Guavas have a sweet or slightly acid flavor when fully ripe and characteristically a weak or pungent and rather penetrating aroma (Menzel, 1985; Morton, 1987; Rathore, 1976; Thonte and Chakrawar, 1982; Wilson, 1980; Yadava, 1994). The growth and development of guava fruit, from the time of fruit set to full maturity and tree-ripe, takes $\approx 150$ days. The ripe guava fruit, which emits a characteristically sweet aroma and possesses a pleasant sweet and sour taste, has a thin skin surrounding the pulp, which consists of a layer of finely granular material on the outside and a mass of softer material in the center (Fig. 1). Numerous small, hard, yellowish to cream-colored seeds (1 to $4 \mathrm{~mm}$ in diameter) are imbedded in the soft pulp. The seedless cultivars of guava, available in many countries around the world, have great potential for becoming popular in the years ahead.

\section{WORLD DISTRIBUTION AND IMPORTANCE}

Guava is important in international trade and domestic economy of more than 50 tropical and other warm countries (Menzel, 1985). Because of its easy cultivation under variable soil and climatic conditions, high nutritional value, and popular use in processed products such as juice, preserves, and dairy or bakery items, guava is a favorite fruit of billions of people around the world, particularly in the tropics and the warm subtropics. Due to their astringent properties, the edible mature fruit, the leaves, the root, the bark, and the immature fruit are used in local medicines to treat gastroenteritis, diarrhea, and dysentery (Morton, 1987; Purseglove, 1968). The intake of guava fruit has 


\section{WORKSHOP}
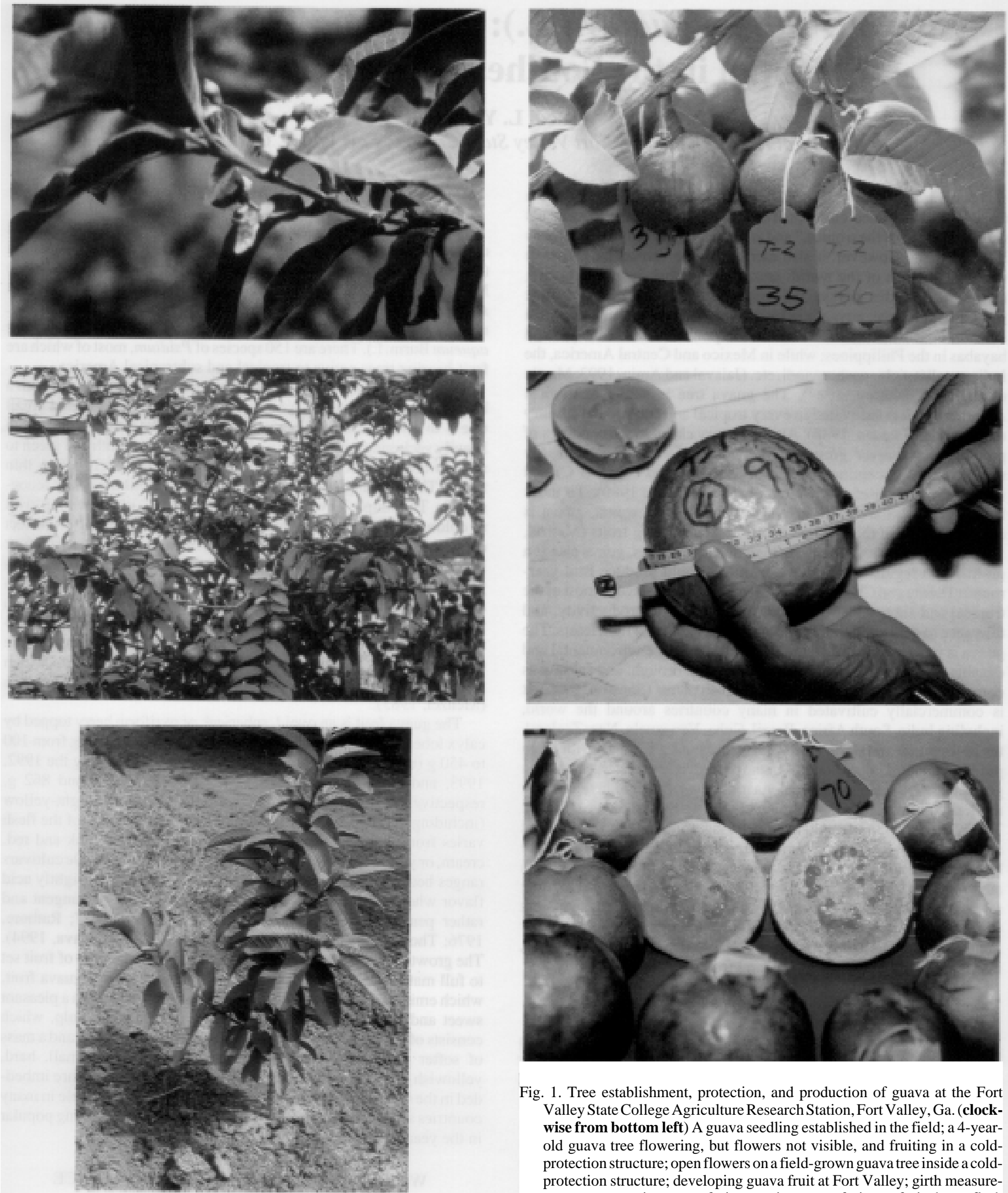

Fig. 1. Tree establishment, protection, and production of guava at the Fort Valley State College Agriculture Research Station, Fort Valley, Ga. (clockwise from bottom left) A guava seedling established in the field; a 4-yearold guava tree flowering, but flowers not visible, and fruiting in a coldprotection structure; open flowers on a field-grown guava tree inside a coldprotection structure; developing guava fruit at Fort Valley; girth measurement on a tree-ripe guava fruit; tree-ripe guava fruit, cut fruit shows flesh color.

\section{CLIMATIC REQUIREMENTS}

significantly reduced serum total cholesterol, triglycerides, and blood pressure with the opposite effect (an explicit increase) on high-density lipoprotein ("good" cholesterol) (Singh et al., 1992). Furthermore, high concentrations of pectin content in guava fruit may play a significant role in reducing cholesterol.

Guava plants tolerate a wide range of frost-free climatic conditions, although mature trees survive light frosts (Campbell, 1984; Jaisval and Amin, 1992; Martin et al., 1987; Rathore, 1976; Samson, 1986). Trees 
thrive well in humid and dry climates between sea level and 2100-m elevation. The optimum conditions for guava cultivation and high yield of good-quality fruit includes temperatures between 20 to $30 \mathrm{C}$ and well-distributed rainfall from 1000 to $2000 \mathrm{~mm}$; however, fruit quality is poor in areas of high rainfall and high relative humidity (Samson, 1986). The best-quality guava fruit are harvested when they mature during the dry period. Thus, it is always beneficial to give trees a rest (an off season) by withholding irrigation water periodically. Guava bears more heavily in areas with a distinct winter season than in the deep tropics (Morton, 1987).

\section{PROPAGATION}

Guava is generally propagated from seeds, although trees raised from seedlings are known to be variable in plant and fruit characteristics. For example, seedling trees of guava are not as precocious as vegetatively propagated trees, which can start fruiting in just 2 to 3 years vs. 4 to 5 years for seedling trees. Seedling trees are, therefore, economically less desirable than clonally propagated plants. The tendency of seedling trees to underuse the land area, to have a lower productivity per unit of canopy area, and, hence, be less profitable than clonal trees are the primary reasons for preferring the latter (Sharma et al., 1992). Guava is very difficult to root from mature wood. Thus, propagation from rooted cuttings is not reliable. However, vegetative propagation of guava from hardwood cuttings using bottom heat, along with plant growth regulators and benzoic acid, has been achieved successfully (Prasad et al., 1988). Asexually propagating guava using layering, air-layering, inarch grafting and budding of scions from desirable guava cultivars onto superior guava rootstock types is as achievable as it is with mango (Mangifera indica L.) and citrus. Sharma et al. (1992) reported a positive influence of an aneuploid No. 82 dwarfing rootstock on tree growth and productivity of guava. At the Horticultural Experiment and Training Center, Basti, India, a unique system of patch budding of guava scions has been shown to be commercially feasible (Morton, 1987). Several advanced and practical clonal methods for effective propagation of guava germplasm have been discussed by Chandra (1965). Nevertheless, guava can be induced to set fruit and produce fairly good yield of marketable fruit during the first season following budding, or other vegetative multiplication procedure, and transplanting clonal trees into field plots.

Emerging biotechniques for tissue culture and micropropagaton of superior guava cultivars have been discussed by several researchers during the past decade (Amin and Jaisval, 1988; Jaisval and Amin, 1987; Loh and Rao, 1989; Papadatou et al., 1990). A technique for successful in vitro propagation of guava germplasm using shoot-tip explants from mature trees has been reported by Jaisval and Amin (1987). These workers also demonstrated that adding activated charcoal to the medium enhanced rooting of explants and vegetative growth of established plantlets. Rapid multiplication of seedling plants of guava through in vitro shoot-tip culture and subsequent plant establishment also have been successful (Papadatou et al., 1990).

\section{GENETIC DIVERSITY AND PLANT IMPROVEMENT}

The common guava is a diploid tree fruit species with $2 \mathrm{n}$ equal to 22. However, natural and artificial triploids $(2 \mathrm{n}=3 \mathrm{x}=33)$, including some aneuploid cultivars or selections, also are known to exist. Triploids generally produce seedless fruit (Jaisval and Amin, 1992), but, economically, they are mostly shy bearers (Menzel, 1985), and thus, their production needs to be improved. Seedling trees of the majority of guava cultivars display great genetic diversity in tree vigor and size, bearing habit and fruit yield, shape, size, quality, ripening season, and storage characteristics. Guava is traditionally propagated from seed; nevertheless, natural cross-pollination, which is common in cultivated guava, reaching up to $35 \%$ in some cases (Purseglove, 1968), is mainly responsible for the variability observed in seedlings. Vegetative means have been used successfully to propagate guava. Nonetheless, trees resulting from marcot and rooted cuttings appear to be susceptible to high wind damage due to their poor root system (Menzel, 1985). Crosses between 'Allahabad Safeda', a guava of good quality and heavy bearer but seeded, and a natural triploid, seedless but a very shy bearer, produced several aneuploids, including No.-82, which holds potential for future research on guava improvement (Sharma et al., 1992). Somaclonal variation, as in other crop species, has potential use in improving guava resistance to certain diseases. Endosperm culture may be gainfully used for producing seedless triploid plants. Additionally, callus cultures of guava germplasm would be helpful in selecting for resistance to pathogens and environmental stresses in desirable cultivars (Jaisval and Amin, 1992).

\section{IMPORTANT CULTIVARS}

As reported by Jaisval and Amin (1992) and Menzel (1985), the guava cultivars could be classified into three distinct types: 1 ) desserttype cultivars produce less acidic fruit with mostly white flesh and appealing skin colors-'Allahabad Safeda', 'Lucknow 49', 'Tathem White' are some of them;2) processing-type cultivars produce strongly acidic fruit, generally with colored (mostly red) flesh and a high percentage of pulp recovery- 'Ka Hua Kula'; 3) Dual-purpose cultivars produce fruit that are a compromise between the processing and the dessert requirements of fruit- 'Etheridge Selection', 'Oakey Pink', 'Fanretief', etc. Thus, 'Allahabad Safeda', 'Sardar' (Lucknow 49), 'Red Fleshed', 'Chittidar', and 'Nasik' are the best-known desserttype guava cultivars of India that produce good yields of high-quality eating fruit. The best Hawaiian cultivars are 'Beaumont', 'Ruby Supreme', and 'Ka Hua Kula', while 'Supreme' and 'Elisabeth' are famous guava clones from the Ivory Coast. 'Centeno Pacific', the famous cultivar from Trinidad, which produces in excess of $50 \mathrm{t}$ of fruit per hectare, can be easily propagated by rooted cuttings and is tolerant to flooding. 'Etheridge Selection', 'Oakey Pink', 'Tathem White', 'Ka Hua Kula', and 'Indonesian Seedless' are other important guava cultivars. Nagar and Raja Rao (1983) reported that the fruit of seeded 'Allahabad Safeda' grow much larger than those of the seedless 'Allahabad Seedless'. These scientists attributed such differences in seedlessness to the fluctuating endogenous auxin contents during guava fruit growth. Similar influences of endogenous cytokinins and gibberellins on the fruit growth in guava also have been illustrated by these researchers.

\section{CULTIVATION}

Production. The guava plant, which is highly adaptable to various manipulations, is cultivated successfully in a wide range of growing conditions and is fairly well adjusted to variations in rainfall and to soil $\mathrm{pH}$ ranging from 4.5 to 8.2 or slightly higher. Soil type really does not matter much for guava cultivation, particularly when other edaphic and environmental conditions are not at limiting levels. Guava is tolerant to poor soil conditions, but fruit production is enhanced considerably when it is grown in rich soils under proper management. As a general rule, however, guava plants require little attention. Where mass production is not desired and space is limited, guava trees can be grown as cordons on wire fences. Depending on factors such as guava type or cultivar, soil type and fertility, and cultural management, trees can be planted from 2.4 to $7.5 \mathrm{~m}$ in any combination desired for rows and tree spacing. The most common spacings are $3 \times 3,3 \times 4.5,4.5 \times$ 4.5 , and $4.5 \times 6 \mathrm{~m}$, with trees being planted along the contour of the land. Nevertheless, to overcome the problems inherent with the large tree planting systems, Mohammed et al. (1984) developed the multiple-shoot meadow, or super-intensive system of growing guava, as one of the most efficient modern systems, particularly with respect to reducing labor demand and enhancing fruit production. They tested $27,000(0.6 \times 0.6 \mathrm{~cm}), 37,000(0.9 \times 0.3 \mathrm{~cm})$, and 73,000 $(0.45 \times 0.3$ $\mathrm{cm})$ plants per hectare in combination with the use of several plantgrowth-retarding substances as treatments for plant dwarfing and vigor control. Their observations clearly indicated that, at the planting density of 27,000 plants/ha, there were more fruit per plant, resulting in higher yield of good-quality fruit than at higher planting densities.

Pruning. Regular and proper pruning of bearing trees of guava is very important. Most of the guava trees, whether propagated from seed or as grafted trees, produce an abundance of suckers that should be removed to keep the stem free and clean at least up to $50 \mathrm{~cm}$ above the ground. A framework of preferably four strong branches, individually 
located in four quarters of the tree, should be established. The crotch angle between the branches and the main stem should be wide enough to facilitate adequate penetration of light and provide physical strength to support fruit load at maturity. Well-shaped trees should be maintained through regular but light pruning of vertical shoots and removal of dead and/or unwanted wood. Due to the natural habit of guava plants to bear fruit on new and emerging vegetative growth from mature wood, it is very important to keep a good balance between the amount of vegetative growth and mature wood to ensure the next season's production and, thus, maintain fruiting regularity for steady income.

Fruit bearing. Guava trees grow rapidly and begin fruiting in 2 to 5 years, depending on whether they are produced from seeds (Morton, 1987) or clonally propagated from mature wood (Martin et al., 1987). Regardless of the time of year, flowers are always borne on newly emerging vegetative shoots arising from mature wood. Thus, guava plants can flower in every month of the year in equatorial environments. Nevertheless, in the northern growing regions of India, it flowers two to three times a year (rainy, winter, and spring season crops) and decidedly three times in the southern part of the country (Rathore, 1976; Samson, 1986; Singh and Joon, 1984). In a mild tropical or cool subtropical climate, guava can flower and fruit continuously throughout the year if water and temperatures do not become limiting factors (Rathore, 1976). The growth curve for guava fruit is double rather than single sigmoidal as had been reported in the past (Rathore, 1976; Sastry, 1965a). Rathore (1976) described three distinct periods of growth for guava fruit: 1) Period of rapid fruit growth—starting a few days after anthesis and continuing through next 45 to 60 days, depending on the fruiting season of the year in areas with multiple cropping seasons; 2) period of relatively slow fruit growth-lasting only for 30 to 60 days. During this time, seeds attain full maturity and become very hard. 3) Period of exponential increase in fruit size-lasting another 30 to 60 days following slow growth and ending at the time of fruit maturity; fruit height and diameter increase markedly during this period, leading the fruit to "eating ripeness." Moreover, the duration of all three growth periods of guava fruit appeared to be inversely proportional to the prevailing temperatures. Depending on guava cultivar or type and the growing conditions, it takes $\approx 100$ to 150 days from bloom to fruit harvest (Rathore, 1976; Samson, 1986). During the fruit growth period, the major activities appear to be synthesis of cell wall material and sugars, while the pectins rapidly increase during the ripening period (Sastry, 1965b).

Fruit thinning. Since healthy guava trees fruit abundantly, there is always a chance that fruit-bearing branches will break. Thinning in the early stages of fruit growth and development may help the remaining fruit attain proper size, and may not only reduce breakage of branches, but also promote bearing regularity and uniformity in the areas with multiple fruiting seasons (Biswas et al., 1989). Hand-thinning is the common procedure, and chemical fruit thinning has not been popular so far.

Pest problems. Guava fruit flies (Anastrepha striata Schiner and Certatitis capitata Wiedemann) are the most important pests. Infestations are sometimes so heavy that the fruit may be virtually crawling with larvae. Phosphorothioic acid O,O-diethyl O-[6-methyl-2-(1methylethyl)-4-pyrimidinyl] ester (diazinon) and 1-naphthalenol methylcarbamate; methyl carbamic acid 1-naphthyl ester; 1-naphthyl $\mathrm{N}$-methylcarbamate (sevin) are used against fruit flies in Surinam and Trinidad (Bharath, 1969; van Brussel and van Vreden, 1968). Occasional damage to the leaves of most guava cultivars is done by scale insects, mites, thrips, and the white flies (Campbell, 1984). To my knowledge, there are no control measures available for sucking moth, birds, or fruit bats (Menzel, 1985). Root-knot nematodes (Meloidogyne spp.) damage tree roots in lighter soils and use of selected nematicides may provide protection. Among serious diseases of guava, oak rootrot fungus [Clitocybe tabescens (Fn.) Berz.] causes crown and root rots, leading to tree death; Cephaleuros virescens Kunze alga is responsible for superficial spotting of fruit and leaves, sometimes resulting in defoliation; while Colletotrichum gloeosporioides Penz. causes ripe fruit to rot. Blossom-end rot, fruit cankers, and anthracnose could be very serious on rainy season guava crops in some growing areas.

Harvesting and storage. As we have observed with fruit harvested from trees at Fort Valley, Ga., immature guava fruit do not ripen off the trees. Such fruit may soften somewhat, but they never develop full color, nutritional quality, and typical guava flavor associated with good eating enjoyment (Menzel, 1985). Overripe fruit drop off trees. To my knowledge, there are no chemical indices or physical criteria for fruit that can consistently reflect the correct stage of ripening for fruit harvest. Personal experience is the best guide to determine the right stage. Thus, fruit harvesting should be carried out at the turning stage when the fruit is fully developed and has started turning color from green to yellowish. Ripening and storage of guava fruit have been discussed in great detail by Prasad and Shukla (1979). Storage at cool temperatures extends postharvest fruit life up to 5 weeks with good retention of fruit quality and no significant reduction in nutrient content; however, improperly stored fruit may loose some moisture (Yadava, 1994). Singh et al. (1990) characterized primary stresses that limit the storage life of guava fruit as desiccation, browning of fruit skin tissue with concomitant loss of flesh firmness, and high rate of physiological weight loss. Investigations on organoleptic ratings and other physiological characteristics indicate that guava fruit should be packed in the natural posture (with the pedicel end of the fruit kept upward) to retain better quality for longer periods (Siddiqui et al., 1991).

\section{NUTRITIONAL VALUE}

The guava fruit is considered an excellent source of ascorbic acid (AA) (Rathore, 1976; Yadava, 1994). Additionally, it is also abundant in dietary fiber, vitamin A, pectin, phosphorus, calcium, and potassium (Wilson, 1980; Yadava, 1994). The concentration of AA varies among cultivars and cultivated guava types (Thonte and Chakrawar, 1982). Reportedly, fresh fruit is a very rich source (up to $2000 \mathrm{mg} / 100$ g) of AA (Campbell, 1984; Martin et al., 1987; Menzel, 1985); redfleshed fruit contains $3 \mathrm{mg}$ of carotene/100 g of fruit and $8 \%$ to $20 \%$ carbohydrates. The predominant nonvolatile organic compounds include citric, malic, lactic, ascorbic, and galacturonic acids (Chan et al., 1971). Furthermore, in cultivated guava types, citric and malic acids were almost in equal concentrations, while they contained much less lactic acid than either of the other two acids; however, in the wild types, citric acid was the predominant acid, with lesser amounts of malic and lactic acids. In addition to its appealing nutritional qualities, other alluring criteria in guava that attract consumer attention are its sweet to sour taste, its characteristic aromatic pulp, its attractive fruit shape, and variable flesh and surface colors (Martin et al., 1987; Yadava, 1994). The strong aroma of guava fruit is attributed to carbonyl compounds (Morton, 1987). Nutritional analysis of guava fruit produced at FVSC has been compared with the ranges of various nutrients reported in the literature (Table 1).

\section{USES}

The guava fruit has long been a staple food of several countries (Menzel, 1985). It is still a standard dessert throughout Latin America and the Spanish-speaking islands of the West Indies, and is also consumed as stewed guava shells (cascos de guayaba), that is, guava halves with central seed pulp removed (Rathore, 1976). Bars of thick, rich guava paste and guava cheese are staple sweets, and guava jelly is widely marketed in these countries. There are innumerable recipes for using guava fruit in pies, cakes, puddings, sauce, butter, sherbet, marmalade, jam, some dairy products (guava cheese and guava ice cream), chutney, relish, catsup, bakery products, and other products (Menzel, 1985; Rathore, 1976). Guava pulp can be eaten fresh, stewed, as juice or nectar, jelly, paste, preserve, etc. Jain and Barker (1966) have discussed preparation of beverages from guava. In South Africa, guava fruit pulp mixed with cornmeal makes breakfast food flakes. The roots, bark, leaves, and green fruit are used as medicine in the tropical world to halt gastroenteritis, diarrhea, and dysentery (Rathore, 1976). Crushed leaves are applied on wounds, ulcers, and rheumatic places while whole leaves are chewed to relieve toothache.

\section{RESEARCH EFFORTS IN GEORGIA}

Guava trees planted during May 1990 in a winter-protection house in the field bloomed in flushes starting in late Winter 1990-91 and 
Table 1. Comparative nutritional analysis (all per $100 \mathrm{~g}$ fruit) of guava fruit harvested during 11 Oct. and 8 Nov. 1994 from 'Red Fleshed' guava trees grown at Fort Valley, $\mathrm{Ga}^{2}$

\begin{tabular}{|c|c|c|c|}
\hline Guava constituents & Fort Valley & Reported & References $^{\mathrm{y}}$ \\
\hline \multicolumn{4}{|l|}{ General } \\
\hline Ash content (mg) & $424 \pm 36$ & $400-700$ & $\mathrm{~EB}, \mathrm{MJ}, \mathrm{SM}$ \\
\hline Carbohydrates (g) & $14 \pm 1.5$ & $10-20$ & $\mathrm{~EB}, \mathrm{MJ}$ \\
\hline Dietary Fiber (g) & $5.1 \pm 1.3$ & $3.0-6.9$ & $\mathrm{~EB}, \mathrm{HC}, \mathrm{MJ}$ \\
\hline Fat $(\mathrm{g})$ & $0.19 \pm 0.07$ & $0.1-0.6$ & $\mathrm{~EB}, \mathrm{HC}, \mathrm{MJ}$ \\
\hline Moisture (g) & $85 \pm 1.5$ & $75-85$ & $\mathrm{~EB}, \mathrm{MJ}, \mathrm{RD}$ \\
\hline Protein $(\mathrm{g})$ & $1.40 \pm 0.02$ & $0.8-1.6$ & $\mathrm{~EB}, \mathrm{HC}, \mathrm{MJ}, \mathrm{SM}$ \\
\hline \multicolumn{4}{|l|}{ Vitamins } \\
\hline Ascorbic acid (mg) & $305 \pm 14$ & $300-1000$ & $\mathrm{~EB}, \mathrm{HC}, \mathrm{RD}, \mathrm{SM}$ \\
\hline Total vitamin A $(\mu \mathrm{g})$ & $69 \pm 13.5$ & $250-400 \mathrm{IU}$ & $\mathrm{EB}, \mathrm{MJ}$ \\
\hline ß-carotene $(\mu \mathrm{g})$ & $44.4 \pm 11.4$ & No report & --- \\
\hline B-cryptoxanthin $(\mu \mathrm{g})$ & $25.0 \pm 7.5$ & No report & --- \\
\hline Niacin $(\mu g)$ & $774 \pm 87$ & $0.6-1.20$ & $\mathrm{~EB}, \mathrm{MJ}$ \\
\hline Riboflavin $(\mu \mathrm{g})$ & $80 \pm 1.0$ & 30-90 & $\mathrm{EB}, \mathrm{MJ}$ \\
\hline Thiamine $(\mu \mathrm{g})$ & $50 \pm 7.0$ & $40-60$ & $\mathrm{~EB}, \mathrm{MJ}$ \\
\hline \multicolumn{4}{|l|}{ Minerals } \\
\hline $\mathrm{Ca}(\mathrm{mg})$ & $9.12 \pm 1.5$ & $9.0-25$ & $\mathrm{~EB}, \mathrm{MJ}, \mathrm{SB}$ \\
\hline $\mathrm{Cu}(\mu \mathrm{g})$ & $208 \pm 10.4$ & No report & --- \\
\hline $\mathrm{Fe}(\mu \mathrm{g})$ & $840 \pm 51$ & $300-900$ & $\mathrm{~EB}, \mathrm{HC}, \mathrm{MJ}$ \\
\hline $\mathrm{Mg}(\mathrm{mg})$ & $11.6 \pm 1.4$ & No report & --- \\
\hline $\operatorname{Mn}(\mu \mathrm{g})$ & $114 \pm 9$ & No report & --- \\
\hline $\mathrm{P}(\mathrm{mg})$ & $21.8 \pm 3.2$ & $18-42$ & $\mathrm{~EB}, \mathrm{MJ}$ \\
\hline $\mathrm{K}(\mathrm{mg})$ & $201 \pm 23$ & $270-290$ & $\mathrm{~EB}$ \\
\hline $\mathrm{Na}(\mathrm{mg})$ & $1.30 \pm 0.19$ & $3.0-5.5$ & EB \\
\hline $\mathrm{Zn}(\mu \mathrm{g})$ & $252 \pm 41$ & No report & --- \\
\hline
\end{tabular}

${ }^{\mathrm{z}}$ Nutritional analyses were carried out at the Dept. of Food Science and Technology, College of Agricultural and Environmental Science, Univ. of Georgia, Athens.

${ }^{\mathrm{y}} \mathrm{EB}=$ Encyclopedia Britannica (Preece, 1981); HC = Hacket and Carolane, 1992; MJ = Morton, 1987; RD = Rathore, 1976; SB = Singh et al., 1990; SM $=$ Sastry, 1965, 1965b.

continued to the end of 1991, with fruit maturation and ripening following the same pattern (Yadava, 1992). Fruit weight during the 1991-92 season varied from 236 to $597 \mathrm{~g}$ with an average of $435 \pm 8$ g. Tree-ripe fruit had a pink tinge on yellow-green skin (Fig. 1); the pink- to red-colored, thick flesh had a mild aroma and a good flavor. Some fruit ripening in late fall showed an unusual, so far unidentified, tissue damage due to necrosis in the mesocarp. Despite this minor drawback, overall results obtained at our research station indicate that a substantial crop of good-quality guava can be produced successfully in the middle Georgia area if protection against freezing temperatures is provided. Additionally, fully mature and tree-ripe guava fruit, harvested during Sept.-Dec. 1993 from field-grown trees protected by 0.15-mm-thick, plain, clear polyethylene, were examined for physical attributes and nutrient content (Yadava, 1994). Measurements on harvested fruit were made for fresh weight, fruit girth (horizontal) and height (vertical), fruit volume by water displacement, and fruit surface and flesh color evaluations. Fruit skin color was measured on all fruit, while for flesh color, a few selected fully ripe fruit were halved for color measurement using $\mathrm{L} * \mathrm{a} * \mathrm{~b} *$ values on a tristimulus color analyzer (chromameter, model CR-200; Minolta Corp., Ramsey, N.J.) equipped with an 8-mm-diameter measuring head area. The $\mathrm{L}^{*}$ scale of the L*a*b* Commission Internationale de l'Eclairage (CIE) coordinates ranges from no reflection $\left(\mathrm{L}^{*}=0\right.$, black) to perfect diffused reflection $\left(L^{*}=100\right.$, white); $a^{*}$ scale ranges from negative values for green to positive values for red; and the $b^{*}$ scale ranges from negative values for blue to positive values for yellow (Robbins and Moore, 1992). The 1993 seasonal average of the $L^{*} a * b *$ values for guava fruit skin and flesh colors were $+65.61,-6.86,+39.37$ and $+55.86,-35.41$, +19.48 , respectively.

During 1992-93, there were 342 fruit per tree with an average fruit weight of $292 \mathrm{~g}$, fruit girth $66 \mathrm{~cm}$, and vertical height $19 \mathrm{~cm}$. Nutritional analyses of the fruit grown at the FVSC Agricultural Research Farm and held under refrigerated conditions from 1 to 5 weeks indicated that these fruit were high in ascorbic acid, potassium, protein, and total dietary fiber but low in fat and sodium. The fully developed and mature fruit harvested at the turning stage kept well for 5 weeks at 10C. Except for a modest weight reduction resulting from the loss of moisture from the open skin surface of unwrapped fruit, the storage had no serious influence on nutrient content. These findings suggest the relevance of cool storage for guava fruit. Our guava crop from the 1994 season was even bigger than that of the previous crops, with the largest fruit weighing $862 \mathrm{~g}$ compared to $756 \mathrm{~g}$ in the 1992 93 season. This enhancement in guava production may have resulted from larger tree size, improved cultural management, or both.

\section{COMMERCIAL POTENTIAL IN THE UNITED STATES}

In many countries, guava is often considered a weed, yet it has the potential to contribute to the commercial horticulture not only in the warm and subtropical regions of the United States, but also in the temperate zones adjoining these subtropics. This fruit tree can withstand high levels of moisture, high salt concentrations, and moisture stress, which gives this plant the ability to grow on marginal lands unsuitable for major crops. Therefore, guava culture appears to have great potential to improve farm economy. The timely protection of guava trees from severe frosts and freezes appears to be the only problem with growing it in temperate-zone climates. Thus, its inherent characteristics, such as environmental versatility, precocity, bearing regularity, ease of cultivation, and uniformity of high production coupled with the emerging plant biotechnologies, favor its commercial development in other areas of the United States. At present, guava is important in home and market gardens in most tropical countries and many subtropical areas. Processed products of guava are an important part of international trade (Campbell, 1984; Menzel, 1985).

Guava is adapted to variable climatic and edaphic conditions. Highly productive and rich in nutritive value, exudates from guava tree roots inhibit weed growth (Rathore, 1976). These characteristics, combined with the availability of production technology, the increasing ethnic population in the United States portending a new or expanded market for guava products, and the general public's mere fascination with the fruit enhance the potential for guava production to nontraditional guava-growing areas.

\section{Literature Cited}

Amin, M.N. and V.S. Jaisval. 1988. Micropropagation as an aid to rapid cloning of a guava cultivar. Scientia Hort. 36:89-95.

Bharath, S. 1969. Producing guava for the factory. Ministry Agr., Land, \& Fisheries Crop Bul. 13, Trinidad.

Biswas, M., A.K. Azad, A. Ahmed, and A.K.M.A. Hossain. 1989. Effect of fruit thinning on fruit size, yield and quality of Kazi Piara guava. Bangladesh Hort. 17:1-4.

Campbell, C.W. 1984. Guava: Tropical fruits and nuts, p. 254-256. In: F.W. Martin (ed.). CRC handbook of tropical food crops. CRC Press, Boca Raton, Fla.

Chan, H.T., J.E. Brekke, and T. Chan. 1971. Nonvolatile organic acids in guava. J. Food Sci. 36:237-239.

Chandra, D. 1965. Recent advances in clonal propagation of guava. Allahabad Farmer 39:137-139.

Cobley, L.S. 1976. An introduction to the botany of tropical crops. 2nd ed. (revised by W.M. Steel). Longman, New York.

Hackett, C. and J. Carolane. 1982. Edible horticultural crops: A compendium of information on fruits, vegetables, spices and nut species. Academic, Sydney, Australia.

Jain, N.L. and D.H. Barker. 1966. Preparing beverages from guava fruit. Indian Hort. 11:5-7.

Jaiswal, V.S. and M.N. Amin. 1987. In vitro propagation of guava from shoot cultures of mature trees. J. Plant Physiol. 130:7-12.

Jaiswal, V.S. and M.N. Amin. 1992. Guava and jackfruit, p. 421-431. In: F.A. Hammerschlag and R.E. Litz (eds.). Biotechnology of perennial fruit crops. Biotech. Agr. 8. CAB International, Wallingford, U.K.

Loh, C.S. and A.N. Rao. 1989. Clonal propagation of guava (Psidium guajava L.) from seedling and grafted plants and adventitious shoot formation in vitro. Scientia Hort. 39:31-39.

Martin, F.W., C.W. Campbell, and R.M. Roberte. 1987. Perennial edible fruits of the tropics: An inventory. U.S. Dept. Agr., Agr. Res. Serv., Agr. Hdbk. 642.

Menzel, C.M. 1985. Guava: An exotic fruit with potential in Queensland. Queensland Agr. J. 111(2):93-98.

Mohammed, S., L. Wilson, and N. Prendergast. 1984. Guava orchard meadow. Trop. Agr. (Trinidad) 61:297-301.

Morton, J.F. 1987. Fruits of warm climates. Julia F. Morton Publishers, Miami. 
Nagar, P.K. and T. Raja Rao. 1983. Endogenous auxins in seeded and seedless fruits of guava. Scientia Hort. 18:323-331.

Papadatou, P., C. Pontikis, E. Ephtimiadou, and M. Lydaki. 1990. Rapid multiplication of guava seedlings by in vitro shoot tip culture. Scientia Hort. 45:99-103.

Prasad, A. and J.P. Shukla. 1979. Studies on the ripening and storage behaviour of guava fruits (Psidium guajava). Indian J. Agr. Res. 13:39-42.

Prasad, J., A. Rabbani, and R.A. Ram. 1988. Rooting of hardwood cuttings of guava (Psidium guajava) through bottom heat. Progressive Hort. 20:2023.

Preece, W.E. (ed.). 1981. Fruit nutrient composition table. Encyclopedia Brit. vol. 7. p. 766.

Purseglove, J.W. 1968. Tropical crops-Dicotyledonous. Longman, London.

Rathore, D.S. 1976. Effect of season on the growth and chemical composition of guava (Psidium guajava L.) fruits. J. Hort. Sci. 51:41-47.

Robbins, J.A. and P.P. Moore. 1992. Fruit quality of stored, fresh red raspberries after a delay in precooling. HortTechnology 2:468-470.

Samson, J.A. 1986. Tropical fruits. 2nd ed. Trop. Agr. Ser., Longman Scientific \& Technical, New York.

Sastry, M.V. 1965a. Biochemical studies in the physiology of guava. I. Physical changes. Indian Food Packer 19:1-4.

Sastry, M.V. 1965b. Biochemical studies in the physiology of guava. II. Major chemical changes. Indian Food Packer 19:5-10.

Sharma, Y.K., A.M. Goswami, and R.R. Sharma. 1992. Effect of dwarfing aneuploid guava rootstock in high density orcharding. Indian J. Hort. 49:31-36

Siddiqui, S., R.K. Sharma, and O.P. Gupta. 1991. Physiological and quality response of guava fruits to posture during storage. HortScience 26:1295-1297.

Singh, B.P., S.K. Kalra, and D.K. Tandon. 1990. Behavior of guava cultivars during ripening and storage. Haryana J. Hort. Sci. 19:1-6.

Singh, R.B., S.S. Rastogi, R. Singh, S. Ghosh, and M.A. Niaz. 1992. Effects of guava intake on serum total and high-density lipoprotein cholesterol levels and on systemic blood pressure. Amer. J. Cardiol. 70:1287-1291.

Singh, R.R. and M.S. Joon. 1984. Seasonal influence on physico-chemical composition of guava fruit. South Indian Hort. 32:88-89.

Thonte, G.T. and V.R. Chakrawar. 1982. Physico-chemical characters of the certain types/strains of guava (Psidium guajava L.). Progressive Hort. 14:269-272.

van Brussel, E.W. and G. van Vreden. 1968. Studies on the biology, damage and control of guava fruit fly Anastrepha striata in Surinam. Surinam Landb. 16:110-122.

Wilson, C.W. 1980. Guava, p. 279-299. In: S. Nagy and P.E. Shaw (eds.). Tropical and sub-tropical fruits: Composition, properties, and uses. AVI, Westport, Conn.

Yadava, U.L. 1992. Feasibility of growing guava under the conditions of middle Georgia. HortScience 27:604.

Yadava, U.L. 1994. Physicochemical properties of guava produced in Georgia. HortScience 29:536-537.

\title{
Moringa (Moringa oleifera Lam.): A Versatile Tree Crop with Horticultural Potential in the Subtropical United States
}

\author{
Manuel C. Palada \\ Agricultural Experiment Station, University of the Virgin Islands, Rural Route 2, Box 10,000, Kingshill, St. Croix, \\ U.S. Virgin Islands 00850
}

\section{IMPORTANCE}

Moringa is a perennial softwood tree of many uses. It is known by several names, including horseradish tree, ben oil tree, drumstick, and sohnja in India; benzolive, benzolivier, ben oleifere, bambou-bananier, and graines benne in Haiti; reseda, ben, and jazmin frances in Puerto Rico; palo de aceite, palo de abejas, and libertad in Dominican Republic; paraiso de Espana and paraiso in Central America; marango in Costa Rica; perlas and paraiso blanco in Guatemala; teberinto in El Salvador; jacinto in Panama; maranga calalu in Honduras; angela in Colombia; saijhan in Guiana; moloko and ben-aile in Guadeloupe; shagarat al rauwag in Sudan; and murunga-kai, balunggay, or malunggay in the Philippines (Benge, 1987).

The multiple uses and potentials of moringa have attracted the attention of researchers, extension workers, development agencies, and farmers in major regions of the world. The moringa tree is an important crop in India, Ethiopia, Sudan, and many countries in Asia and Central America, where its parts, from roots to seeds, are used for industrial, food, and medicinal purposes (Bhattacharya et al., 1982; Girija et al., 1982; Hartwell, 1982; Mayer and Stelz, 1993; Ramachandran et al., 1980; Verma et al., 1976). Recently, moringa is being used as hedgerow species for windbreak and in agroforestry/ alley cropping systems (O'Donnell and Palada, 1993; O'Donnell et al., 1994; Palada, 1992; Palada et al., 1994; Price, 1992). The objective of this article is to describe moringa as a tree crop based on literature review and to discuss its potential for cultivation in the United States.

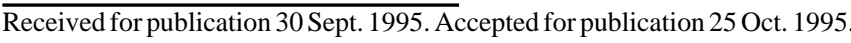
The cost of publishing this paper was defrayed in part by the payment of page charges. Under postal regulations, this paper therefore must be hereby marked advertisement solely to indicate this fact.

\author{
ORIGIN AND BOTANY
}

Moringa originated in India and Arabia. It is widely cultivated or naturalized in several countries in the tropics. It is a slender, deciduous tree with drooping leaves, and it grows to about $10 \mathrm{~m}$ tall (Fig. 1). The branches and stems are brittle, with corky bark. The leaves are feathery, pale green, compound, tripinnate, 30 to $60 \mathrm{~cm}$ long, with 3 to 9 leaflets on the ultimate pinnules (Brown, 1950). Each leaflet is 1.3 to $2.0 \mathrm{~cm}$ long and 0.6 to $0.3 \mathrm{~cm}$ wide. Lateral leaves are somewhat elliptical, while the terminal ones are obovate and slightly larger than the lateral ones. The flowers are fragrant, white or creamy-white with yellow stamens; $2.5 \mathrm{~cm}$ in diameter, borne in sprays. The pods are pendulous, brown, triangular, tapering at both ends, 30 to $120 \mathrm{~cm}$ long and $1.8 \mathrm{~cm}$ wide, and contain about 20 seeds embedded in the pith. Pods split lengthwise into three parts when dry. Seeds are dark brown with three papery wings. The main root is thick. The tree flowers and produces pods and seeds throughout the year (Ramachandran et al., 1980).

\section{GEOGRAPHICAL DISTRIBUTION}

Moringa grows in ecologies ranging from subtropical dry to moist through tropical very dry to moist forest life zones. Moringa is reported to tolerate annual precipitation of 760 to $2250 \mathrm{~mm}$, annual temperatures of 18.7 to $28.5 \mathrm{C}$, and soil $\mathrm{pH}$ of 4.5 to 8 . It is drought tolerant and thrives in subtropical climates, flowering and fruiting freely. Moringa performs best on a dry sandy soil, but grows in all types of soils, except heavy clays (Duke, 1978).

\section{CULTIVATION}

Moringa is propagated either by planting stem cuttings 1 to $2 \mathrm{~m}$ long or by seed. In Sudan, traditional cultivation involves seeds, 

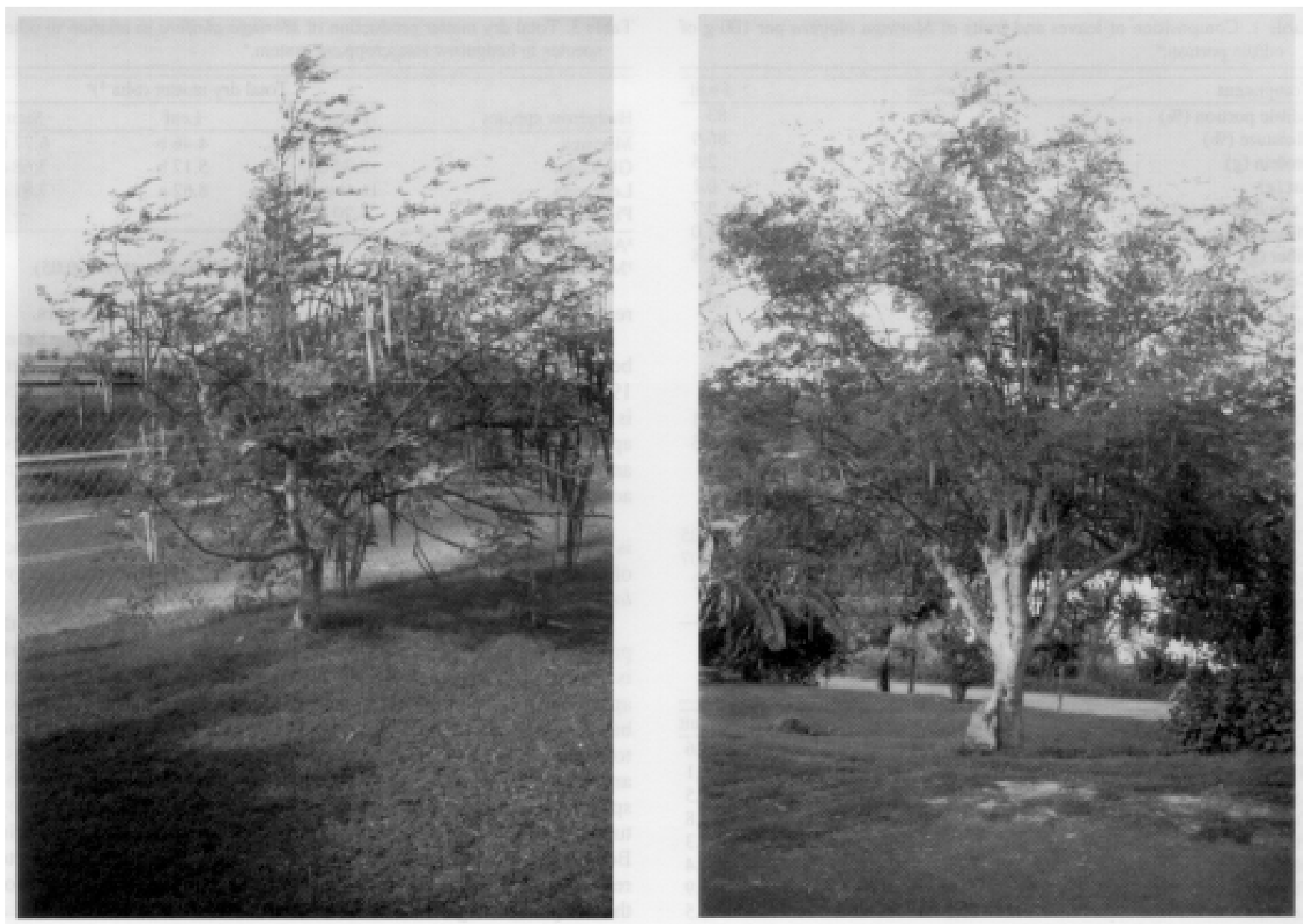

Fig. 1. A (left) young (3 years old) moringa and (right) an old (10 years old) moringa tree.

whereas vegetative propagation is very common in India, Indonesia, and parts of West Africa. Cuttings, which root very easily, are usually preferred.

Plants raised from seeds produce fruit of inferior quality (Ramachandran et al., 1980). Furthermore, fairly large cuttings, planted in moist soil, root readily and grow to sizeable trees within a few months. In India, large limb cuttings of 100 to $135 \mathrm{~cm}$ long and 14 to $16 \mathrm{~cm}$ in circumference are planted in situ in the rainy season. Unproductive trees are cut down, leaving a stump, from which one to two shoots are allowed to grow. From these shoots, cuttings, $200 \mathrm{~cm}$ long and 4 to $5 \mathrm{~cm}$ in diameter, are selected and used as planting material (Peter, 1979; Seemanthani, 1964).

Moringa is planted at a spacing of 3 to $5 \mathrm{~m}$ both between and within rows, and watered until the plants are well established. Regular irrigation and manuring are rarely practiced; but in the state of Kerala, India, ring trenches are dug around the trees, and green leaves, farmyard manure, and ash are put in the trenches about $10 \mathrm{~cm}$ away from trees during the rainy season. This practice is said to promote high dry matter yield. Research work at the Tamil Nadu Agricultural Univ. in India has shown that application of $7.5 \mathrm{~kg}$ of farmyard manure and $0.37 \mathrm{~kg}$ of ammonium sulfate per tree gave a three-fold increase in dry matter yield over trees with no fertilizer application (Sundararaj et al., 1970).

Trees raised from stem cuttings bear in 6 to 8 months after planting. The yield is generally low in the first 2 years, but from the third year on, a single tree yields 600 or more fruit per year (Ramachandran et al., 1980).

\section{USES}

Moringa has multiple uses which are generally classified into 1) food, 2) agronomic or horticultural, 3) medicinal, and 4) industrial (Benge, 1987; Duke, 1987).

\section{Food uses}

According to Price (1985), moringa is one of the most amazing trees God has created. Almost every part of moringa is said to be of value for food. In the Philippines, recipe pamphlets have been published on how to cook moringa (Food and Nutrition Research Center, 1987; Lanuza, 1987). The leaves of moringa are high in vitamins A and $\mathrm{C}$, and a cupful of leaves provides more than the recommended daily allowance (Table 1). They have the general characteristics of a leafy vegetable rich in $\mathrm{Ca}$ and $\mathrm{Fe}$ and are a very good source of $\mathrm{P}$. They are particularly valuable on account of their $\mathrm{Ca}$ and $\mathrm{Fe}$ contents. The leaves are eaten as greens, in salads, in vegetable curries, as pickles, and for seasoning (Duke, 1987; Martin and Ruberte, 1979; Ramachandran et al., 1980). The young fruits have the general characteristics of a succulent vegetable, but are rather high in protein (Table 2). In Southeast Asia, the young pods are cooked as a vegetable (Peter, 1979; Ramachandran et al., 1980). The seed is said to be eaten like a peanut in Malaysia. The thickened roots provide a popular horseradish-like condiment in Asia and Africa.

The flowers are said to make a satisfactory vegetable, which is interesting, particularly in subtropical places such as Florida, where it is said to be the only tree species that flowers every day of the year (Price, 1985). The tree is also good for honey production, because bees are very attracted to its flowers (Jahn et al., 1986).

\section{Agronomic and horticultural uses}

Moringa has several agronomic and horticultural uses. Perhaps the most common use is as hedgerows or field borders serving as a living fence or providing windbreak (Jahn et al., 1986). In some parts of Southeast Asia, the tree is used to support cultivation of climbing crops such as yams, pole beans, and black pepper. In India and Indonesia, moringa leaves are used as animal fodder. In certain parts of Ethiopia, 
Table 1. Composition of leaves and fruits of Moringa oleifera per $100 \mathrm{~g}$ of edible portion. ${ }^{\mathrm{z}}$

\begin{tabular}{lcc}
\hline Component & Leaves & Fruit \\
\hline Edible portion (\%) & 75 & 83 \\
Moisture (\%) & 75.0 & 86.9 \\
Protein (g) & 6.7 & 2.5 \\
Fat (g) & 1.7 & 0.1 \\
Carbohydrate (g) & 13.4 & 3.7 \\
Minerals (g) & 2.3 & 2.0 \\
Fiber (g) & 0.9 & 4.8 \\
Calories & 92 & 26 \\
Ca (mg) & 440 & 30 \\
Mg (mg) & 24 & 24 \\
Oxalic acid (mg) & 101 & 101 \\
P (mg) & 70 & 110 \\
K (mg) & 259 & 259 \\
Cu (mg.g-1) & 1.1 & 3.1 \\
Fe (mg) & 7 & 5.3 \\
S (mg) & 137 & 137 \\
Vitamin A (I.U.) & 11,300 & 184 \\
Choline (mg) & 423 & 423 \\
Thiamine (mg) & 0.06 & 0.05 \\
Riboflavin (mg) & 0.05 & 0.07 \\
Nicotinic acid (mg) & 0.8 & 0.2 \\
Vitamin C (mg) & 220 & 120 \\
\hline Adapted from Ayl & &
\end{tabular}

${ }^{\mathrm{z}}$ Adapted from Aykroyd (1966).

Table 2. Protein fractions of Moringa oleifera leaves and fruit $(\mathrm{g} / 16 \mathrm{~g} \mathrm{~N}){ }^{\mathrm{z}}$

\begin{tabular}{lcc}
\hline Component & Leaves & Fruit \\
\hline Arginine & 6.0 & 3.6 \\
Histidine & 2.1 & 1.1 \\
Lysine & 4.3 & 1.5 \\
Tryptophan & 1.9 & 0.8 \\
Phenylanaline & 6.4 & 4.3 \\
Methionine & 2.0 & 1.4 \\
Threonine & 4.9 & 3.9 \\
Leucine & 9.3 & 6.5 \\
Isoleucine & 6.3 & 4.4 \\
Valine & 7.1 & 5.4 \\
\hline
\end{tabular}

$\overline{{ }^{z} \text { Adapted from Wealth of India (1962) as cited by Ramachandran et al. (1980). }}$

leaves and young branches are browsed and relished by livestock (Le Houerou and Corra, 1980). In the Philippines, the roots are used as a nematicide (Guzman, 1984), and leaves are known to prevent damping-off disease of seedlings (Price, 1993, 1995). In Latin America, United States, and Africa, moringa is grown as an ornamental tree (Jahn et al., 1986).

The potential of moringa in alley cropping and agroforestry for sustainable vegetable production is being investigated at the Univ. of the Virgin Islands Agricultural Experiment Station in St. Croix. Moringa is grown in hedgerows along with other hedgerow species, such as leucaena [Leucaena leucocephala (Lam.) de Wit], gliricidia [Gliricidia sepium (Jacq.) Walp.], and pigeonpea [Cajanus cajan (L.) Millsp.]. Moringa is second to leucaena in terms of total dry matter (biomass) production and higher than gliricidia after 2 years of growth (Table 3). Leucaena and moringa exhibited the fastest regrowth after pruning (O’Donnell et al., 1994). Application of prunings adds organic matter and improves soil fertility. Moringa, however, is highly competitive to eggplant (Solanum melongena $\mathrm{L}$.) and sweet corn (Zea mays L.) planted in alleys, reducing yields of these crops by more than $50 \%$ (Palada et al., 1994). In southern Florida, sweetpotato [Ipomoea batatas (L.) Lam.] varieties have been evaluated for growth and yield response to alley cropping with moringa (Price, 1990).

\section{Medicinal uses}

Moringa has many medicinal properties, including abortifacient, antidote (centipede, scorpion, spider), bactericide, diuretic, ecbolic, estrogenic, expectorant, purgative, rubefacient, stimulant, tonic, vermifuge, and vesicant (Duke, 1987). Most of the plant's parts have medicinal values. The flowers are anthelmintic and cure inflammations, muscle diseases, tumors, and enlargement of the spleen. According to Hartwell (1982), the flowers, leaves, and roots are used in folk
Table 3. Total dry matter production of Moringa oleifera in relation to other species in hedgerow intercropping system. ${ }^{2}$

\begin{tabular}{lccc}
\hline \hline & \multicolumn{3}{c}{ Total dry matter $\left({\left.\mathrm{t} \cdot h \mathrm{~h}^{-1}\right)^{\mathrm{y}}}\right.$} \\
\cline { 2 - 4 } Hedgerow species & Plant & Leaf & Stem \\
\hline Moringa & $11.2 \mathrm{~b}$ & $4.46 \mathrm{~b}$ & $6.77 \mathrm{~b}$ \\
Gliricidia & $8.85 \mathrm{c}$ & $5.12 \mathrm{~b}$ & $3.68 \mathrm{c}$ \\
Leucaena & $16.6 \mathrm{a}$ & $8.62 \mathrm{a}$ & $7.81 \mathrm{a}$ \\
Pigeonpea & $4.20 \mathrm{~d}$ & --- & -- \\
\hline
\end{tabular}

${ }^{2}$ Adapted from O'Donnell et al. (1994).

${ }^{y}$ Mean separation in columns by Duncan's multiple range test $(P \leq 0.05)$.

remedies for various tumors, and the seed for abdominal tumors.

Two alkaloids, moringine and moringinine, are present- the latter being responsible for many of the medicinal uses of the plant (Peter, 1979). In Nicaragua, the root decoction is used for dropsy. Root juice is applied externally as a rubefacient or counterirritant. The leaves are applied as a poultice on sores, rubbed on the temples for headaches, and said to have purgative properties. The bark, leaves, and roots are acrid and pungent, and are taken to promote digestion (Duke, 1987).

Oil from moringa seed is somewhat toxic if taken internally, but it is applied externally for skin diseases. In Guatemala, aqueous extract of moringa seed is effective against the skin-infecting bacteria Staphylococcus aureus and Pseudomonas aeruginosa (Price, 1992).

The bark is regarded as antiscorbic and exudes a reddish gum with properties of tragacanth; sometimes used for diarrhea. The stem bark is known to remove all kinds of pain. It is said to be a fattening agent, aphrodisiac, anthelmintic, and useful to cure eye diseases. The root bark has aphrodisiac qualities and is used against intestinal worms and to reduce all sorts of aches. It causes a burning sensation, biliousness and improves appetite. It also is given to prevent enlargement of the spleen and formation of tuberculous glands in the neck; to destroy tumors; and to heal ulcers, earaches, and shuttering of the ear. In Bombay, a decoction of the root bark is used as a fermentation to relieve spasm (Peter, 1979). The root is bitter and used as a tonic for the body and lungs, and to enrich the blood. It is a laxative and a diuretic. It is used to cure inflammations, chest wounds, bronchitis, and piles (Peter, 1979).

\section{Industrial uses}

Moringa have several industrial uses. The seeds yield $38 \%$ to $40 \%$ nondrying oil known as Ben oil. Ben oil is used in arts and for lubricating watches and other delicate machinery. The oil also is used in the manufacture of perfumes and hair dressings (Duke, 1987; Ramanchandran et al., 1980). The wood yields a blue dye. The bark can serve for tanning and yields a coarse fiber. Trees are being studied as pulpwood sources in India. Analysis by Mahajan and Sharma (1984) indicated that the tree is a suitable raw material for producing high alpha-cellulose pulps for use in cellophanes and textiles.

In rural Sudan and Malawi, powdered moringa seeds are used to purify drinking water by coagulation (Bensimon, 1992; Berger et al., 1984; Jahn et al., 1986; Mayer and Stelz, 1993). In trials, the powder was toxic to guppies (Poecilia reticulata), protozoa (Tetrahymena pyriformis), and bacteria (Escherichia coli), and it inhibited acetylcholinesterase. It had no effect on coliphage, lactic dehydrogenase, or invertase, and the equivalent of cotyledon powder up to 1000 mg.liter ${ }^{-1}$ had no mutagenic effect on salmonella. The toxic effects to bacteria, guppies, and protozoa are believed to be due to 4-L-alpha-1rhamnosyloxybenzyl isothiocyanate, a glycosidic mustard oil. In the concentration of seeds used for nutrition, medicine, or water purification (Grabrow et al., 1985), the toxin did not seem to endanger the health of humans. Aside from water purification, moringa also is used for firewood when supplies of other fuel is scarce (Jahn et al., 1986; Mayer and Stelz, 1993).

\section{RESEARCH EFFORTS}

Research activities focus on potential uses of moringa in various parts of the world. Other moringa species are being explored for their horticultural, medicinal, nutritional, and industrial uses (Jahn et al., 1986). Species with potential uses are M. stenopetala (Bak. F.) Cuf., 
M. peregrina (Forssk.) Fiori, M. drouhardii Jumelle, M. longituba Engl., and M. ovalifolia Dinter \& Berger. Researchers in Kenya and other countries of East Africa are studying its nutritional value for human food and livestock feed, as well as its potential for low-cost water purification (Mayer and Stelz, 1993).

Research efforts exploring the uses of moringa species have been summarized by Jahn et al. (1986) as follows: vegetable (Asia, Africa, America); spice (Asia, Africa); cooking oil and cosmetics (Asia, Madagascar, Africa); water coagulant (Sudan, Malawi, Indonesia, Ethiopia); honey clarifier (Sudan); honey tree (India); medicinal plant (Asia, Africa, Central America); nematicide and fungicide (Philippines); fodder (India, Indonesia); fences and windbreak (Asia, Africa, Central America, Caribbean); support for climbers or vine plants (Asia); firewood (Togo, India); and ornamental tree or shrub (Central and South America, United States, Africa, Saudi Arabia).

Few research activities are undertaken in the United States because the tree can only grow in the tropics and subtropics. In southern Florida, near Miami and Homestead, moringa can be grown successfully to produce flowers and seeds. According to Mary Lamberts (1994, personal communication), a Filipino farmer near Homestead, Fla., grows moringa and ships it to large cities such as Detroit, Chicago, and New York. He also sells some in local markets near Miami. In Hawaii, some growers ship moringa leaves for specialty market in Canada (Hector Valenzuela, 1992, personal communication). A small-scale research and development effort is being undertaken by the Educational Concerns for Hunger Organization (ECHO), a nonprofit, private, volunteer organization located in North Fort Myers, Fla. This organization collects and distributes moringa seeds in collaboration with interested groups working in developing countries. Workers also share information on experiences with moringa through the organization's newsletter and development notes. The Univ. of the Virgin Islands Agricultural Experiment Station is conducting a research project using moringa in alley cropping systems for sustainable vegetable production. This project will provide valuable information on the potential benefits of moringa in tropical horticulture.

\section{COMMERCIAL POTENTIAL}

As a versatile tree crop, moringa has commercial potential in the United States. Among the many uses of moringa, perhaps the important ones are its medicinal and industrial uses. By-products of seeds, leaves, and roots can be processed to produce, for example, drugs, benoil, soap, cosmetics, coagulants, organic pesticides, and dyes. As an exotic specialty vegetable crop, moringa may have a potential market among the growing ethnic populations in major U.S. cities.

\section{CONCLUSION}

Moringa is a multipurpose tree with agronomic, horticultural, medicinal, nutritional, and industrial uses. It has been the subject of great interest and research throughout the tropics and subtropics. Many developing countries have benefited from its multiple uses. As an exotic crop, the United States can also benefit by cultivating moringa in subtropical regions and processing its by-products into various goods for export. Research and development efforts are needed to explore the potential of moringa in the United States.

\section{Literature Cited}

Aykroyd, W.R. 1966. The nutritive value of Indian foods and the planning of satisfactory diets. Indian Council Med. Res., New Delhi. p. 55, 61, $91,97$.

Benge, M.D. 1987. Moringa: A multipurpose vegetable and tree that purifies water. Sci. \& Technol./For., Environ., \& Natural Resources Tech. Ser. 27. U.S. Agency Intl. Development, Washington, D.C.

Bensimon, C. 1992. African tree's seeds could replace expensive chemical water purifiers. Ceres 134:3-4.

Berger, M.R., M. Habs, S.A.A. Jahn, and D. Schmahl. 1984. Toxicological assessment of seeds from Moringa oleifera and Moringa stenopetala, two highly efficient primary coagulants for domestic water treatment of tropical water. East Afr. Med. J. 61:712-716.

Bhattacharya, S.B., A.K. Das, and N. Banerji. 1982. Chemical investigations on the gum exudate from sonja (Moringa oleifera). Carbohydrate Res. 102:253-262
Brown, W.H. 1950. Useful plants of the Philippines. vol. 2. Tech. Bul. 10. Bureau of Science, Manila, Philippines.

Duke, J.A. 1978. The quest for tolerant germplasm, p. 1-61. In: G. Young (ed.). Crop tolerance to suboptimal land conditions. Amer. Soc. Agron. Spec. Symp. 32. Madison, Wis.

Duke, J.A. 1987. Moringaceae: Horseradish-tree, benzolive-tree, drumsticktree, sohnja, moringa, murunga-kai, malunggay, p. 19-28. In: M. Benge (ed.). Moringa: A multipurpose vegetable and tree that purifies water. Sci. \& Technol./For., Environ., \& Natural Resources Agro-forestation Tech. Ser. 27. U.S. Agency Intl. Development, Washington, D.C.

Food and Nutrition Research Center, Manila, Philippines. 1987. Learn to eat malunggay, p. 81-84. In: M. Benge (ed.). Moringa: A multipurpose vegetable and tree that purifies water. Sci. \& Technol./For., Environ., \& Natural Resources Agro-forestation Tech. Ser. 27. U.S. Agency Intl. Development, Washington, D.C.

Girija, V., D. Sharada, and P. Pushpamma. 1982. Bioavailability of thiamine, riboflavin and niacin from commonly consumed green leafy vegetables in the rural areas of Andhra Pradesh in India. Intl. J. Vitamin Nutr. Res. 52:913.

Grabrow, W.O.K., J.L. Slabbert, W.S.G. Morgan, and S.A.A. Jahn. 1985 Toxicity and mutagenicity evaluation of water coagulated with Moringa oleifera seed preparations using fish, protozoan, bacterial, coliphage, enzyme and Ames salmonella assays. Water S.A. 11:9-14.

Guzman, R.S. 1984. Toxicity screening of various plant extracts against Meloidogyne incognita Chitwood and Radopholus similes Cobb and characterization of their nematicidal components. PhD Diss., Univ. of the Philippines at Los Banos, Laguna.

Hartwell, J.L. 1982. Plants used against cancer. A survey. Quarterman Publications, Lawrence, Mass.

Jahn, S.A.A., H.A. Musnad, and H. Burgstaller. 1986. The tree that purifies water: Cultivating multipurpose moringaceae in Sudan. Unasylva 38:23-28.

Lanuza, S.A. 1987. Kadyos, papaya, malunggay and seguidilla recipes from the twelve regions of the Philippines, p. 85-98. In: M. Benge (ed.). Moringa: A multipurpose vegetable and tree that purifies water. Sci. \& Technol./For., Environ., \& Natural Resources Agro-forestation Tech. Ser. 27.U.S. Agency Intl. Development, Washington, D.C.

Le Houerou, H.N. and M. Corra. 1980. Some browse plants of Ethiopia, p. 109114. In: H.N. Le Houerou (ed.). Browse in Africa: The current state of knowledge. Intl. Livestock Center for Africa, Addis Ababa, Ethiopia.

Mahajan, S. and Y.K. Sharma. 1984. Production of rayon grade pulp from Moringa oleifera. Indian Forester 110:303-306.

Martin, F.W. and R.M. Ruberte. 1979. Edible leaves of the tropics. 2nd ed. Mayaguez Inst. Trop. Agr., Agr. Res. Serv., U.S. Dept. Agr., Mayaguez, Puerto Rico.

Mayer, F. and E. Stelz. 1993. Moringa stenopetala provides food and low-cost water purification. Agroforestry Today 5:16-18.

O'Donnell, J.J. and M.C. Palada. 1993. Establishment and growth of four hedgerow species for alley cropping in St. Croix. Agron. Abstr. 1993:59.

O'Donnell, J.J., M.C. Palada, S.M.A. Crossman, J.A. Kowalski, and A. Bulbulla. 1994. Growth and biomass production from four hedgerow species. Agron. Abstr. 1994:72.

Palada, M.C. 1992. Alley cropping: An improved agroforestry system with potentials for the Virgin Islands. Virgin Islands Agr. Food Fair Bul. 6:1722

Palada, M.C., J.J. O’Donnell, S.M.A. Crossman, and J.A. Kowalski. 1994. Influence of four hedgerow species on yield of sweet corn and eggplant in an alley cropping system. Agron. Abstr. 1994:72.

Peter, V. 1979. Drumstick: A multi-purpose vegetable. Indian Hort. 23:17-19.

Price, M. 1985. Vegetables from a tree. Educational Concerns for Hunger Org. Update 8:1.

Price, M. 1990. Agroforestry. Educational Concerns for Hunger Org. News 13:1-3.

Price, M. 1992. Effectiveness of a Moringa oleifera seed extract in treating a skin infection. Educational Concerns for Hunger Org. Development Notes 37:4.

Price, M. 1993. Moringa leaves to prevent damping-off disease of seedlings. Educational Concerns for Hunger Org. Notes 42:2.

Price, M. 1995. Leaves of the moringa tree can prevent damping-off disease of seedlings. Educational Concerns for Hunger Org. News 17:2-3.

Ramachandran, C., K.V. Peter, and P.K. Gopalakrishnan. 1980. Drumstick (Moringa oleifera): A multipurpose Indian vegetable. Econ. Bot. 34:276283.

Seemanthani, B. 1964. A study of practices and problems in the cultivation of some perennial vegetables in Madras State. South Indian Hort. 12:1-15.

Sundararaj, J.S., S. Muthuswamy, K.G. Shanmugavelu, and R. Balakrishnan. 1970. A guide on horticulture. 2nd ed. Velan Pathippagam, Coimbatore, India.

Verma, S.C., R. Banerji, G. Misra, and S.K. Nigam. 1976. Nutritional value of moringa. Current Sci. 45:769-770. 